\title{
Teaching Egyptian History: Some Discipline-Specific Pedagogical Notes
}

Kerry M. Muhlestein

kerry_muhlestein@byu.edu

Follow this and additional works at: https://scholarsarchive.byu.edu/facpub

Part of the Biblical Studies Commons, and the Other Religion Commons

\section{Original Publication Citation}

The Journal of Egyptian History, 2/1-2 (29): 173-231

\section{BYU ScholarsArchive Citation}

Muhlestein, Kerry M., "Teaching Egyptian History: Some Discipline-Specific Pedagogical Notes" (2009). Faculty Publications. 848.

https://scholarsarchive.byu.edu/facpub/848

This Peer-Reviewed Article is brought to you for free and open access by BYU ScholarsArchive. It has been accepted for inclusion in Faculty Publications by an authorized administrator of BYU ScholarsArchive. For more information, please contact ellen_amatangelo@byu.edu. 


\section{"Teaching Egyptian History: Some Discipline-Specific Pedagogical Notes," in The Journal of Egyptian History, 2/1-2 (2009): 173-231.}

Kerry Muhlestein

Associate Professor of Ancient Scripture and Ancient Near Eastern Studies Brigham Young University 316Q JSB

Provo, Utah 84602

(801) 442-3911

Kerry_Muhlestein@byu.edu

Abstract: This paper was originally given at the professional workshop IN SEARCH OF EGYPT'S PAST: Problems AND PERSPECTIVES OF THE HistoriogRAPHY OF ANCIENT EGYPT; A North American workshop at the University of British Columbia, Vancouver, inaugurating the Journal of Egyptian History, April 23-24, 2008, most of the remaining papers of which will appear in Fascicle 2 of this journal. While many Egyptologists teach Egyptian history, we often fail to carefully conceive of just what this means. Teaching history is more than conveying facts about a time period, it is also teaching how to analyze and (re)construct history. Our classes may often teach this aspect as well, is it explicit? And are we equipping graduate students with the ability to both do and teach history well? This training has a direct impact on their employability as well as their scholarship. A survey and study of history department outcomes reveals areas we can improve our history teaching and our training of graduate students. Moreover, as Egyptologists, we have a significant offering to make to teaching history. 


\title{
Teaching Egyptian History: Some Discipline-Specific Pedagogical Notes
}

\author{
Kerry Muhlestein
}

Egyptologists, whether philologists, semioticians, or archaeologists, hold in common the need to understand and teach Egyptian history. While most of the topics addressed at the workshop sponsored by this journal, titled IN SEARCH OF EGYPT’S PAST: PROBLEMS AND PERSPECTIVES OF THE Historiography OF ANCIENT EGYPT; A North American workshop at the University of British Columbia, Vancouver, inaugurating the Journal of Egyptian History, April 23-24, 2008, address our ability to properly "do" history, there is a concurrent need to be able to properly teach history. This is partially because the way we teach influences the way we research - and vice versa - which means that our ability to learn, uncover, and research history is affected by our teaching. There are at least two other reasons for addressing our ability to teach history (page 174). One of those is that the students we teach deserve to be taught in the best manner possible. We have an inherent obligation by virtue of our training and positions to enable ourselves to teach Egyptian history to our students as best we can. Another reason is that the way we teach history also affects our graduate students' ability to learn and teach history. This not only has ramifications for their developing ability to become effective Egyptologists, but also on their opportunity to obtain jobs.

This last issue, while mundane, is important. There is no need for a statistical analysis regarding the differential between the number of graduate students in Egyptology and the 
number of available jobs in Egyptology. It is clear that most of our students will not be able to get a job specifically designed for Egyptologists. And thus it is incumbent upon programs that train Egyptologists to prepare them in such a way that they are qualified for jobs elsewhere in academia. These students and the discipline itself suffer a loss if they must leave academia altogether in order to sustain a living, and thus can no longer contribute to the field. The need for helping students find jobs is overly apparent. For example, when asked in a survey of Egyptologists "If you could add an outcome objective for your Egyptian history students, what would it be?" the first free response was "More general, comparative training that enables them to get jobs outside Egyptology, for example in Ancient History or Classics.”

Here we must return in full force to the subject of being able to teach history. Almost all universities and colleges have a history department. Almost none of them have Egyptological positions. However, many history departments are capable of supporting the research program of an Egyptologist who can competently teach history, including Egyptian history.

Thus there are two reasons for learning something from those specifically trained as historians as we approach Egyptian history. One reason is that our ability to recreate history can certainly be enhanced by adopting approaches utilized by those whose full time and training are dedicated to the historian's craft. This is not to say that we have nothing of our own to offer indeed I will argue below that we have much to offer. Nor is it to say that we must adopt the models of learning and research that other disciplines espouse. But undoubtedly there is something we can learn (and to some degree have) from historical methodology as employed in history departments (page 175). 
A second reason is that if we are able to prepare our graduate students in historical methodology, they will not only be able to find good use for it in their studies, but it will make them more qualified for a greater number and variety of positions in the Academy. As a veteran of history departments at several universities, I can attest that teaching the specific history of a given time and place is only part of what history departments want from their faculty, and below I will present the evidence that supports my personal experience. Part of our problem is that most Egyptology graduate students are only trained for that aspect of teaching history; they can impart knowledge of Egyptian history, but struggle with teaching historical methodology, largely because they do not even know what historical methodology is.

\section{Historians' Objectives}

A recent survey of Egyptology graduate students is revealing in this regard (see the appendix for full information regarding the survey). 77\% of Egyptology students who answered the survey either agreed or strongly agreed (most strongly agreeing) that they had a plan for their career after graduation. Most of these planned on teaching, with $90 \%$ likely or very likely to pursue a career in teaching, $7 \%$ undecided, and only $3 \%$ unlikely to pursue a career in teaching. However, as noted above, the market for Egyptological positions cannot accommodate $90 \%$ of our graduate students. This becomes more problematic when we realize that only $57 \%$ of those students surveyed felt that their education had prepared them for many occupational opportunities. The students may be a bit generous in their assessment.

These students largely feel confident in their ability to teach history. 83\% said they would feel confident in applying for a position in a history department, with $17 \%$ not sure, and none who said they would not feel confident. When asked if they were requested to teach a history 
class at a nearby university next week, $10 \%$ felt very prepared, and $67 \%$ felt prepared. Yet $23 \%$ were neutral, a fairly high number of graduate students who are not sure if they could teach history.

It is curious that so many students feel confident in applying for a job in a history department, since many of them do not know what a history department job would entail (page 176). $53 \%$ of the students felt that they knew what universities were looking for in a history teacher, with the other $47 \%$ attesting that they did not know just what a history department wanted. Similarly, 54\% agreed or strongly agreed (mostly agreeing) that their graduate program had prepared them to teach historical methodology. The rest were either neutral or disagreed.

These numbers present a problem. $77 \%$ of students feel they could teach a history class at a university next week, but only $53 \%$ seem to know what the history department would want of them as a teacher in that class, and only $54 \%$ feel they could teach historical methodology. Thus, around $24 \%$ of the students feel they could teach a class, but don't know exactly what they should be teaching. They are likely relying on their ability to impart specific knowledge about events and culture in Egyptian history. It seems that those who are not sure what universities are looking for in history teachers are probably the more informed of the group; they at least have an idea that history departments want something more than someone who can pass along knowledge of a time and place. To be sure, history departments want that, but it is only part of what they want to have happen in a history classroom.

Determining what history departments want out of history teachers, learning what they expect to have happen in the classroom, is not an easy task. This is at least partially because not all history departments want precisely the same thing. It is also partially because not all history 
departments have carefully thought through what they want. Furthermore, in the surveys that I sent out, the history professors had a particularly low response rate, much lower than Egyptologists or Egyptology graduate students. However, many history departments have developed clearly defined outcomes; in other words they have explicitly stated what they expect their history program should enable a student to do. As someone who has trained, tested, and facilitated a variety of academic departments to develop outcomes and outcome assessments, I feel strongly about the value of explicit outcomes. ${ }^{1}$ I have also found that whether or not a department has clearly stated outcomes depends at least partially on how far along their university is in the accreditation process $(177){ }^{2}$ As more and more universities renew their accreditation we will probably find more and more history departments who have carefully thought through what they want to accomplish in their program and have clearly communicated those expectations. $^{3}$

While many of the desired objectives History Departments list differ for their undergraduate programs as opposed to their graduate programs, this makes little difference for our purposes. If an Egyptology student is to prepare to do good Egyptian history, and teach Egyptian history in such a way that it also teaches one how to do history, then the objectives for both groups are applicable and necessary. What we are largely concerned with in this paper is the ability to teach Egyptian history at an undergraduate level, and most of the outcomes discussed below are designed for undergraduates.

1. Astin, Assessment for Excellence, 38-50.

2. I am not alone in this observation. See Wright, “Accreditation - Where Credit Is Due," 49, 54-58.

3. On learning outcomes in General, see Pascarella, et al., How College Affects Students, 3-13. 
After having gone through the stated objectives of 30 history departments, I have been able to garner a picture of the outcomes most commonly held by history programs. Only 4 outcomes were listed by more than half of the programs. The most commonly held goal (21 of the 30 , with a few more that seemed to agree but in too vague a manner to be sure) was that students would be able to "demonstrate the ability to reason through analysis, evaluation, and synthesis of historical evidence,"4 (italics original). The terms analyze, critically read/think/respond, assess, were dominant thoughts in this outcome, typically asking students to be able to employ these skills to evidence, perspectives and contexts.

Surprisingly, coming in a close second in being a common goal (with 20 of the 30 stating this goal) was the ability to "communicate effectively about the past through written and oral presentations." Some departments did not state the medium of communication, but of those that did, writing was always mentioned, but oral communication was nearly as frequent.

It is not until we reach the third most commonly stated outcome (19 of the 30) that we encounter the idea of needing to "develop a deeper knowledge of the history of a particular time and/or place" (page 178). ${ }^{6}$ This outcome could be stated in a variety of ways, such as developing the ability to "display the appropriate level of cognitive knowledge of historical themes and

4. California State University, Department of History, Fullerton, College of Humanities and Social Sciences, Department of History

5. From Brigham Young University Hawaii, College of Arts and Sciences, Department of History website 6. From Columbia University, Department of History website. 
events based upon the student's course of study,"7 or "demonstrate knowledge of diverse historical epochs and regions."8

The fourth outcome that was expressed by more than half (16 of 30) of the departments examined was to enable students to become literate in "historical methods," students' ability to think historically, that is, to use historical method in analyzing problems."10 Stated in other ways, these departments wanted to ensure that students "can pose historical questions about the problems that run through human history,"11 an ability that was sometimes phrased as "methodology in historical studies," 12 or the ability to "employ historical thinking and inquiry." 13 The fact that these terms were fourth in the number of times they were used is somewhat misleading because departments often define historical method in terms of critically analyzing and assessing evidence, language which overlaps with the most commonly stated outcome. This indicates that the language used may obscure a greater commonality: the idea of an appropriate method for analyzing and assessing historical evidence. We will return to this crucial outcome later.

Other outcomes that were commonly stated included developing the ability to work with primary sources (13 of 30), acquiring the ability to conduct research (7 of 30), learning

7. From Iowa State University, Department of History.

8. From Oklahoma State University, Department of History website.

9. From DePaul University, History Department website.

10. From St. Mary's University of Minnesota, Department of History website.

11. From the North Carolina State University, Department of History website.

12. From the University of Colorado at Boulder, Department of History website.

13. From Central Oregon Community College, Department of History website. 
secondary sources, the historiography of a discipline and gaining an appreciation of multiculturalism (also stated as the universality of the human condition), all of which were outcomes in 5 of the 30 programs. ${ }^{14}$

The conclusions gained from examining program outcomes were largely confirmed by the survey we administered to professors of history, with a few significant exceptions (page 179). Unfortunately we did not have a high response rate from those professors who were asked to take the survey, so we must accept these results guardedly. Nevertheless, the way they interact with published program outcomes lends validity to both the survey results and the published outcomes. When creating the survey we asked the same basic question in a few ways in order to ensure that there was consistency of response, and that the way we framed and phrased the questions was not influencing the responses. The results over these questions were uniform, and largely consistent with the desired outcomes outlined above. When asked how important specific objectives were on a sliding scale, the outcome that was reported as most important was the ability to develop reading and writing skills, followed very closely by the ability to perform analysis and critical thinking. ${ }^{15}$ While it reverses the order, this matches very well with the importance placed on these outcomes outlined above. In each case the difference between preferring these outcomes is 1 response or program, indicating that they are seen as equally important, and both are more important than any other goals.

Interestingly, developing a deeper knowledge of the history of a particular time or place was listed as the least important of the choices given. When asked a slightly different way, this

14. For more on the use of outcomes, see Astin, 252-54.

15. On teaching critical thinking in the academy, see Pascarella, et al., 118-121. 
time with a few new options and without the option of gaining specific knowledge, reading and writing was still listed as the most important, with recognizing perspective and bias in primary and secondary sources as the second most important. ${ }^{16}$ These views were confirmed when respondents were asked to rank objectives in order of importance. Reading and writing skills received the highest ranking, followed very closely by the ability to assess and analyze historical contexts and documents (page 180). Gaining an in-depth knowledge of a particular time period was ranked $5^{\text {th }}$ out of five, or the least important. Finally, when asked which objectives most closely matched the outcomes defined by their history department, reading and writing skills were ranked first, Assessing and analyzing historical contexts and documents was second, and gaining an in-depth knowledge was ranked last (out of five possibilities).

When we compare the survey results with the published outcomes, we can, with some confidence, develop a fairly clear picture of what history departments consider essential to being a competent historian. Clearly, communication and analysis abilities are the highest priorities. As we will discuss below, the second of these overlaps with acquiring historical methodology, which is also a highly valued outcome. Gaining specific historical knowledge is a priority, but is the least important of the valued objectives. I believe this would come as a surprise to most Egyptology Graduate students. Knowing this about history departments should affect the way they approach learning and teaching history.

\section{The Historical Method}

16. Two of the respondents were consistent outliers, listing every stated outcome as either very unimportant or unimportant. Assuming that they think something is important, it would appear that they misunderstood the response device, and believed they were marking "important" when they were marking "unimportant". Whether this is the case or not does not affect the results dramatically, since the results were so uniform in their rankings. If we were to switch their responses around it does not change which outcomes were seen as more important than others, it only enhances the trend already present. 
Of the top four desired outcomes in History Departments, three are not problematic for the field of Egyptology. While I have found no Egyptology programs with clearly defined outcomes, it seems reasonable to assume that we attempt to teach our students to analyze, synthesize, assess, and critically reason through historical issues. Some programs may concentrate more on communication skills than others, but in dissertation-oriented programs, this cannot lie too far beyond the bounds of intended goals. Moreover, university attendance in general tends to raise communication abilities. ${ }^{17}$ Acquiring specific knowledge about Egyptian history is also a regular part of Egyptological programs. But what of the historical method? An analysis of our survey material, of required courses, and of courses offered, clearly reveals that our students are not specifically trained in historical method. Most are probably somewhat befuddled by the very term. We are often quite poor in using any kind of method, but especially historical method. Yet it is clear that this is important to history programs, and that historians consider mastering historical methodology a part of what enables one to handle history well (page 181).

Furthermore, a close examination of required courses for history majors (over 50 programs were examined) reveals that nearly ${ }^{18}$ all of them require their majors to take one or two courses in methodology. As a result, history programs generally want their teachers to be able to teach these courses, and therefore look askance at hiring someone who may not be able to help handle this teaching load. I am aware of jobs being offered to those coming from fields in the

17. Pascarella, et al., 115-116.

18. Possibly all of them require this, but not all course catalogs contain language that allows the content of the course to be clearly divined. 
ancient Near East on a conditional basis; the condition being that for a year the professor's ability to teach these course would be evaluated, and then the job offer would be reassessed. Clearly the acquisition of historical method impacts the ability of our graduate students to obtain jobs in history departments.

Of course the question of what is meant by the "historical method" is not easily addressed. While the idea of historical methodology is used almost everywhere among history departments, it is defined nowhere. This ethereality and vagueness is probably quite bedeviling to students from other disciplines who are expected to know something of historical method, yet cannot learn exactly what that method is. To establish just what is meant by "historical method" we could turn to those who have been so influential in its development, such as when Mommsen spoke of the need for the "correct evaluation of the available testimony, the correct connection of the seemingly unrelated and contradictory material to establish the actual order of events." ${ }^{19}$ Or to Bloch, who teaches that when examining specific historical evidence, "method demands that it show a certain correspondence to the allied evidences. ${ }^{20}$ Carr defined history as "an unending dialogue between the present and the past," and called for an increasing acknowledgement of the role of the historian in that dialogue and for greater self-awareness of interpretation on the part of historians. ${ }^{21}$ Dozens of other authors and works could be consulted (page 182). ${ }^{22}$ Still the meaning of historical method would remain vague. In many ways this paper takes a pragmatic

19. Mommsen, "History and Literature," 192.

20. Bloch, The Historian's Craft, 120.

21. Carr, What is history? See also Gardiner, What is History Today ...?

22. For a good example of applied historical method in an Ancient Near Eastern Society, see Na'aman, Ancient Israel's History and Historiography. 
approach, and in keeping with that approach, we will allow the stated outcomes of History Departments to define what method they expect their students to learn (and thus their teachers to teach).

As far as the purpose of employing the historical method is concerned, it is perhaps best stated by the Central Oregon Community College, who want their students to be able to "employ historical thinking and inquiry to understand and to interpret events, issues, developments, relationships and perspectives of history as well as current trends/issues." ${ }^{, 23}$ As to what historical thinking and inquiry are, a careful examination of history outcomes, which attempt to define method reveal the following commonalities. Students who employ historical methods should demonstrate:

1) An ability to recognize the assumptions and questions involved in any given historical issue. ${ }^{24}$ Otherwise stated as the ability to state research questions, problems, or issues. ${ }^{25}$

2) An ability to analyze and employ primary sources in connection with these assumptions and questions, including the ability to recognize the nature of the source, its perspective and context. $^{26}$

23. From Central Oregon Community College, Department of History website.

24. See Stern, The Varieties of History, 13.

25. From University of Texas El Paso, History Department Vision and Mission Statements.

26. From Norfolk State University, Department of History website; University of Anchorage Alaska website; Iowa State University, website; DePaul University, History Department Learning Outcomes; California State University; City College of New York, Department of History Learning Outcomes; St. Mary's Univeristy of Minnesota website; University of Arizona, General Outcomes; From Brigham Young University website; Oregon Community College website; University of Colorado at Boulder website. 
3) An ability to analyze and employ secondary sources, including the ability to critically evaluate the perspective and context of the secondary source. ${ }^{27}$

4) An ability to employ various bibliographic tools and skills in order to effectively locate relevant primary and secondary sources. This is also frequently referred to as "information literacy" (page 183). ${ }^{28}$

5) An awareness of the basic historiography ${ }^{29}$ of the discipline, ${ }^{30}$ and how the approach each student takes to a historical issue relates to historiographic trends. ${ }^{31}$ This often includes an element of being able to recognize and deal with interpretive conflicts. ${ }^{32}$

6) An ability to synthesize evidence and account for variations in evidence in a logical manner. ${ }^{33}$

7) An awareness of the limitations of evidences. ${ }^{34}$

27. California State University website; City College of New York, Department of History Learning Outcomes; Brigham Young University, Expected Learning Outcomes; Oregon Community College website; University of Colorado at Boulder website.

28. From University of Nevada, Department of History Assessment Plan; DePaul University, History Department Learning Outcomes; California State University website.

29. For a good outline of historiography, see Van Seters, Prologue to History, 86-99.

30. See also Finley, Ancient History, 1-6; and Braudel, "Time, History, and the Social Sciences," 404-408.

31. This is demonstrated well in Schorske's Thinking with History. Incidentally, he includes a chapter about Egypt's influence on history, discussing both Frued's and Breasted's treatment of it.

32. From Iowa State University, Objectives for History Majors; also from DePaul University, History Department Learning Outcomes; University of Anchorage Alaska website; California State University website; St. Mary's University of Minnesota website; Central Oregon Community College website; Oklahoma St. University website.

33. From California State University website; California State University website; BYU Idaho Department of History, Program outcomes.

34. From Brigham Young University website. 
8) An ability to trace and analyze change over time, or, in other words, to recognize continuity as opposed to discontinuity. ${ }^{35}$

9) Familiarity with utilizing appropriate writing and citation styles. ${ }^{36}$

Even a cursory glance at these methodological points reveals that most Egyptologists and Egyptology graduate students are capable of doing these things. For example, we typically produce a strong focus on mastering primary ${ }^{37}$ and secondary sources (including archaeology and archaeological reports) (page 184). ${ }^{38}$ We often teach and write about the limitations of evidence and its variations. Though frequently we are quite deficient in identifying change over time, we have often proved capable of it. Yet there are few courses, books, or modes of training in historiography. ${ }^{39}$ Furthermore, while many graduate students develop most of the abilities outlined above, they are often unaware that they have done so, and are even less aware that in this way they are acquiring historical method. This lack of explicitly teaching and tying into historical methodology - almost a kind of meta-training - eventuates both in a lack of

35. From Norfolk State University, Department of History; Alabama University, The History Department's goals; Alabama University, The History Department's goals; North Carolina State University website; From Brigham Young University website.

36. From Seton Hall University website.; also from University of Arizona; Norfolk State University, Department of History; University of Washington website; California State University website; University of Arizona, General Outcomes; From Brigham Young University; University of Utah website; University of California Merced website; University of Colorado at Boulder website; BYU Hawaii, Program Outcomes.

37. On teaching students how to use ancient written sources, see Finley, 21-46. Finley's book though somewhat dated, is an excellent source for teaching those who study ancient cultures about historical method.

38. On the interaction between written sources and archaeology, see Finley, 7 and 19.

39. I have taught a course in the Historiography of Egyptology myself, and know of a few others who have done so. But this is the exception, not the rule. 
consistently applying method, and in confidence in teaching that method. The former hampers our scholarship, ${ }^{40}$ the second our employability.

\section{Dissonance}

Examining how Egyptologists responded to the same questions posed to History Professors, only in regards to teaching Egyptian history in particular, reveals at least some of the reasons that graduate students are not confident in knowing what History departments want. When asked to rate what students should be trained to do by graduation, developing skills in critical thinking and analysis was tied with developing a deeper knowledge of a particular time as the most important objectives. Contrast this with the response from historians, who also thought that analytical skills were important, but ranked gaining a specific knowledge set as the least important of the objectives from which they could choose. Clearly Egyptologists have some different priorities. This is to be expected. We are, after all, a different discipline. Yet as we attempt to train our students to be good historians as a subset of being good Egyptologists, it is helpful to see where we differ from our colleagues in the History Department (page 185).

Egyptologists were not as consistent in their answers as were historians. When asked a similar question, without the option of gaining specific knowledge, Egyptologists felt that recognizing perspective and bias in primary and secondary sources was the most important (by a large lead), and that reading and writing skills were next in priority. Recognizing perspective and bias is similar to gaining critical analysis skills, which were seen as important in the first question. But in the first question reading and writing skills were not viewed as important as

40. As was demonstrated, for instance, in John Gee's presentation at the workshop, which will appear in future issues of this journal. This is not unique to Egyptologists among those that study the ancient Near East. See Kitchen's Relaibaility for an excellent example of how to apply method to the evaluation of sources and history, and for scathing reviews of those in Biblical studies who fail to apply method well. 
gaining specific knowledge. Those same skills become the second-place desired skill when specific knowledge was not an option (they were a somewhat distant third in the first question). There is some uniformity in this pattern of responses. Analysis is important. Seemingly specific knowledge is equally important, with reading and writing skills prioritized after that. However, this picture is blurred when considering the results of another question. When asked to rank in order of importance certain skill sets, Egyptologists ranked reading and writing skills as most important, research skills were next, followed by an essential tie for last place between gaining specific knowledge, analyzing historical contexts and documents, and appreciating past cultures. It is quite curious that in some cases analysis of contexts and documents ranks very high and in this question much lower. It is equally curious that the same thing happens for gaining specific knowledge.

While the picture painted here is confusing, it may also be illustrative. Egyptologists seem to have a less clear and common vision of what they want to train their students to do. Some of this is likely a result of Egyptology programs not establishing explicit outcomes. It may also be partially due to how we view ourselves. For example, in the open ended question which asked Egyptologists what skills should be taught but are currently not, one respondent said "I think that reading, writing, speech, and critical thinking should be taught, but not by me. I am an Egyptologist. Those skills should be taught by specialists in those areas. Our institution does not teach any of them. I do the best I can, but this is not my area of expertise”. Another stated "Reading/writing is sometimes a problem but in our department we, as a faculty, agree that we cannot teach these skills in addition to our own specialty skills. If they are lacking we encourage students to get more training in these areas from our university writing programs (page 186). We 
realize that there are potential problems with this approach, however, and do try to find a balance".

The impression given by the pattern of responses in the survey, including the various free response questions, is that there is some agreement among Egyptologists as to what skills students need to acquire, but much less agreement as to who is responsible for providing the training in these skills. A plausible hypothesis, then, is that those students who specialize in Egyptology early in their academic career are likely to never take courses, which specifically aim at developing some necessary skills. Good students will probably largely pick up these skills along the way, but doing so haphazardly they will both be less effective in applying them, and less confident in their ability to teach these skills to others - partially because they may be unaware of exactly what skills they are employing and need to be teaching. These deficiencies may get them by in Egyptological positions, but will hamper their efforts to find employment in related disciplines. Addressing these deficiencies will make them better Egyptologists and better suited for a wider variety of posts.

\section{Solution Suggestions}

While there is no perfect solution, and while each academic program will have to work their way through dealing with this issue, I would like to make three suggestions which I believe are fairly simple to implement but will do much good.

While we have made strides in collaborating with anthropological colleagues in the academy, ${ }^{41}$ we have done much less with our friends in history. It is not unreasonable to interact 185.

41. See Jeffreys, "Two Hundred Years of Ancient Egypt," 6-7; and Champion, "Beyond Egyptology," 161- 
with our history colleagues in our various institutions in regards to this matter. Almost surely there are classes which we can either require or recommend our students to take in history departments which will help them develop methods, skills, and confidence in those skills and methods. Gateway courses and graduate seminars can be worked into a curriculum for Egyptology students in a beneficial way. A formal introduction into the discipline of History will be of immense benefit (page 187). ${ }^{42}$

Yet we have as much to offer to historians as they do for us. There may be no more fertile ground for teaching historical method than in Egyptian history, for this is a subject, which sequentially takes a student through the introduction of every sort of source imaginable. The key is to be explicit about teaching historical method in our Egyptian history classes, and to seek out examples of Egyptian history that highlight various portions of that method. Research has shown that if we outline desired objectives on our syllabus, and then intentionally work those objectives into our lessons and assignments, and explicitly tie those lessons and assignments into the stated objectives for the students, that greater student learning occurs. ${ }^{43}$ Furthermore it enhances confidence in employing acquired objectives. I will outline just a few of the many possibilities of teaching the historical methods outlined above while teaching Egyptian history. This is not intended to be an exhaustive list, or even to be the best available examples. Instead is should serve as a model which will stir ideas within the reader as to how each class can best accomplish teaching methodology.

42. On the application of historical method for ancient history, see Van Seters, 6-7.

43. See Student Learning Assessment, 10, 12, 19-21; Entwistle, "Promoting Deep Learning Through Teaching and Assessment," 12-16; Banta, et al. Assessment in Practice, 23-25; and Biggs, "Assessing for Quality in Learning," 66-67. 
1) An ability to recognize assumptions and questions: While there are many examples of assumptions being made within the discipline of Egyptology, a telling example arises early within an Egyptian history class. The historiography behind misunderstandings of whether Fayum A or Fayum B culture were earlier provides an excellent example of how assumptions color conclusions. The assumption that Lake Moeris has been under a consistent shrinking pattern created a need to explain away data. It was only when new data brought this assumption into question that scholars even realized their conclusions were based on an assumption, and that they were then able to let the data speak for itself.

2) An ability to properly use primary sources. Egyptian history is rife with possibilities for understanding sources. Because the study of Egyptian history witnesses the introduction of written sources, and because there is such a dramatic evolution of these sources, the need to understand the nature and context of sources is more apparent than in most history classes (page 188). Additionally, our reliance on archaeology as a historical source allows the student to develop an appreciation for the variety of sources available, and their inherent strengths and limitations. For example, walking students through the story of pre-dynastic history as understood from archaeology forces students to examine the possibilities of archaeological sources, their limitations, and their relationship to other sources, such as the art of Hierakonpolis tomb 100 and the writings of Manetho. The introduction of early king lists and royal labels not only provides opportunity for discussion of writing, but also introduces students to the ancient Egyptian sense of historiography. The propagandistic nature of works such as the Prophecies of Neferti or the Kadesh Battle Inscriptions forces students to learn to think of perspective, context, and bias. Old Kingdom autobiographies and Wisdom Literature affords wonderful teaching 
opportunities regarding how to extrapolate culture as well as event from texts. If our graduate students understood how to showcase this one aspect of opportunity to teach method in Egyptian history, they would greatly enhance their employability within the Academy.

$3 \& 5$ ) Introducing students into a few examples of how academic articles and books have biases, and how these sources also represent the venue for working out ideas in the academy, allows students to become able evaluators of secondary sources. Research has already shown that students learn to read critically and analyze better when they are shown the back-andforth discussion of ideas that takes place within the volumes of journals. ${ }^{44}$ For example, students can read Harco Willems' ideas about how to read Ankhtifi's tomb inscription, ${ }^{45}$ and Jan Assmann's initial and later reactions to this idea, ${ }^{46}$ and even what others have done with the viewpoints presented in this exchange. ${ }^{47}$ Viewing this discourse not only introduces students to the ideas discussed, but also helps them to learn that articles do not exist in a vacuum, but take place within a specific historiography (page 189). Furthermore, students will implicitly be taught that not everything written can be taken at its word. Reading a well-argued and well-researched disagreement highlights the need for critical reading in a meaningful way. If similar exchanges are assigned for a variety of topics in history, a very basic sense of historiography is also developed. However, for students to really understand the winds and trends of the discipline, a

44. Graff, Clueless in Academe, 21-32; Hatch, "The Volleyball Effect," 1; and Cohen, The Combing of History, 51-77.

45. Willems, "Crime, Cult and Capital Punishment," 27-54.

46. Assmann, "Inscriptional Violence and the Art of Cursing," 43-65; "When Justice Fails," 149-162; and The Mind of Egypt: History and Meaning in the Time of the Pharaohs, 99.

47. For example, see Morschauser, Threat-Formulae in Ancient Egypt, 20; and Muhlestein, "Empty Threats?" 115-130 
course in historiography is necessary. ${ }^{48}$ This need is something each department must evaluate on its own.

It should be obvious that with careful planning, each of the objectives of historical methodology can be taught within an Egyptian history class. Bibliographies can be required, with students pointed toward appropriate centers on campus to develop the correct skills; examples of gaps in historical data can be presented; and discussions on continuity and change abound within the pages of Egyptian history. Each aspect of historical method is easily demonstrated and taught in an Egyptian history class. Furthermore, teaching and working with these ideas can (and must) be easily worked into graduate programs with various seminars chosen to highlight one or two of the methodological points. Both in the case of an Egyptian history course and within a structured graduate program, all that is really needed is to be cognizant of what historical methodology consists of, and to be conscious and explicit in teaching it. In short, Egyptologists can be some of the best teachers of historical method on campus, which will also help them employ it better and be better employed.

48. By Historiography I mean both modern historiography, as outlined in Redford, "History and Egyptology," 23-35; and Hoffman, Egypt Before the Pharaohs; as well as the ancient Egyptians' ideas about history, as outlined in Van Seters, 160-180; and Tate, "Never Had the Like Occurred." 
Appendix: Survey Report

\section{Methodology:}

Three online surveys distributed through Qualtrics.com, online survey database software that provides the link and records the data from each respondent. One survey was sent to history professors by way of a random sample. After collecting a list of the top 50 universities rated academically and listed alphabetically, the first listed full professor alphabetically received the link to the survey (page 190). The Egyptologists received the survey by way of scholarly connections, in order to access the small group of Egyptologists currently working in the United States. Finally, the graduate student survey was distributed to graduate students in the Egyptology programs, by way of Internet student listings.

Results of Survey Administered to Egyptology Graduate Students

\section{Please respond to the following statements:}

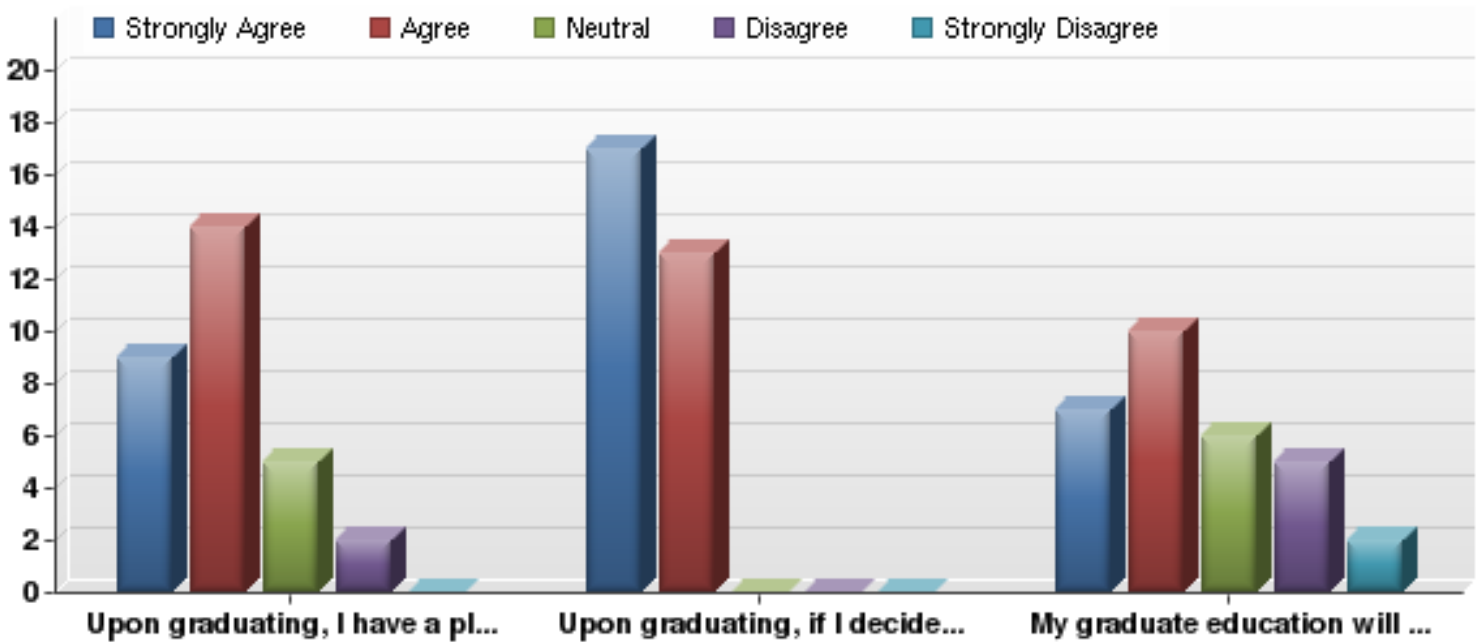

\begin{tabular}{|c|c|c|c|c|c|c|c|c|}
\hline$\#$ & Question & $\begin{array}{c}\text { Strongly } \\
\text { Agree }\end{array}$ & Agree & Neutral & Disagree & $\begin{array}{l}\text { Strongly } \\
\text { Disagree }\end{array}$ & Responses & Mean \\
\hline 1 & $\begin{array}{l}\text { Upon graduating, I } \\
\text { have a plan for my } \\
\text { career. }\end{array}$ & 9 & 14 & 5 & 2 & 0 & 30 & 2.00 \\
\hline 2 & Upon graduating, if I & 17 & 13 & 0 & 0 & 0 & 30 & 1.43 \\
\hline
\end{tabular}


decided to pursue a position in teaching at a University, I would feel qualified to do so.

My graduate education

3 will prepare me for many occupational opportunities
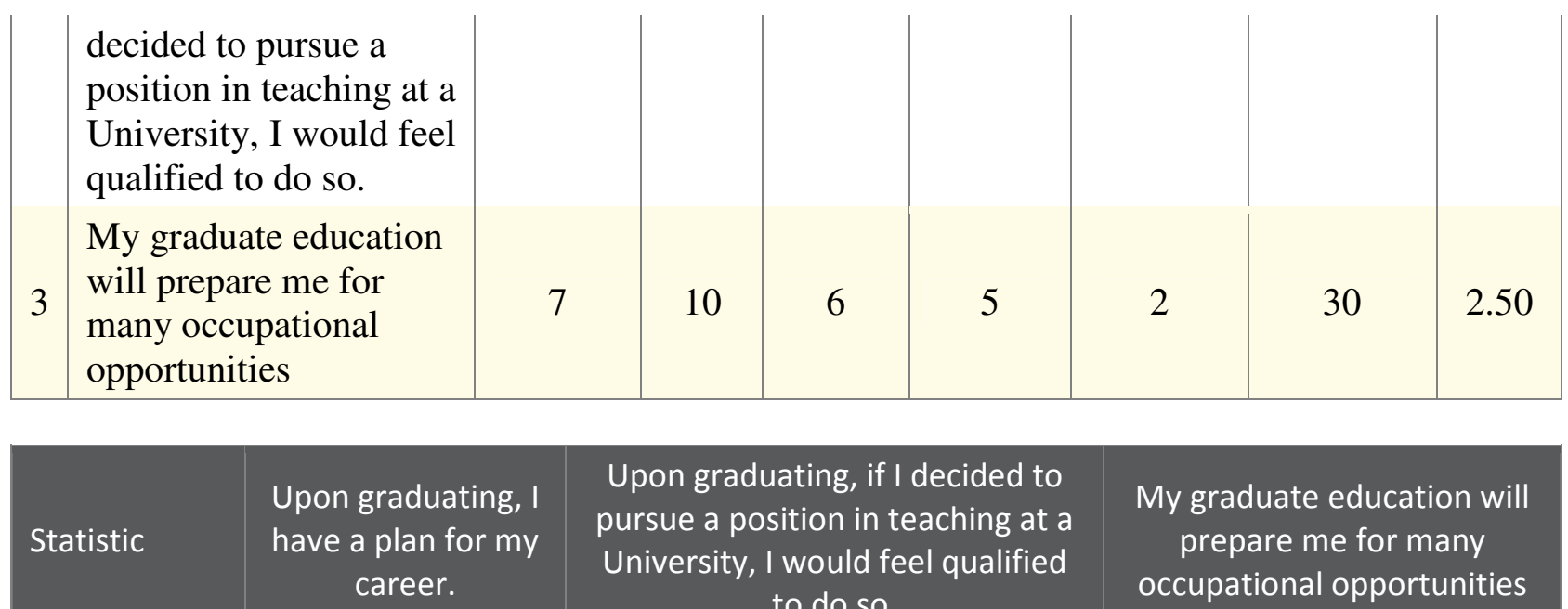

Upon graduating, if I decided to pursue a position in teaching at a University, I would feel qualified to do so.
My graduate education will prepare me for many occupational opportunities

\begin{tabular}{l|c|c|c|} 
Mean & 2.00 & 1.43 & 2.50 \\
Variance & 0.76 & 0.25 & 1.50 \\
Standard & 0.87 & 0.50 & 1.22 \\
Deviation & & & 30 \\
Total & 30 & 30 & \\
Responses & & & \\
\hline
\end{tabular}

\section{My graduate program has prepared me to teach historical methodology (page 191).}

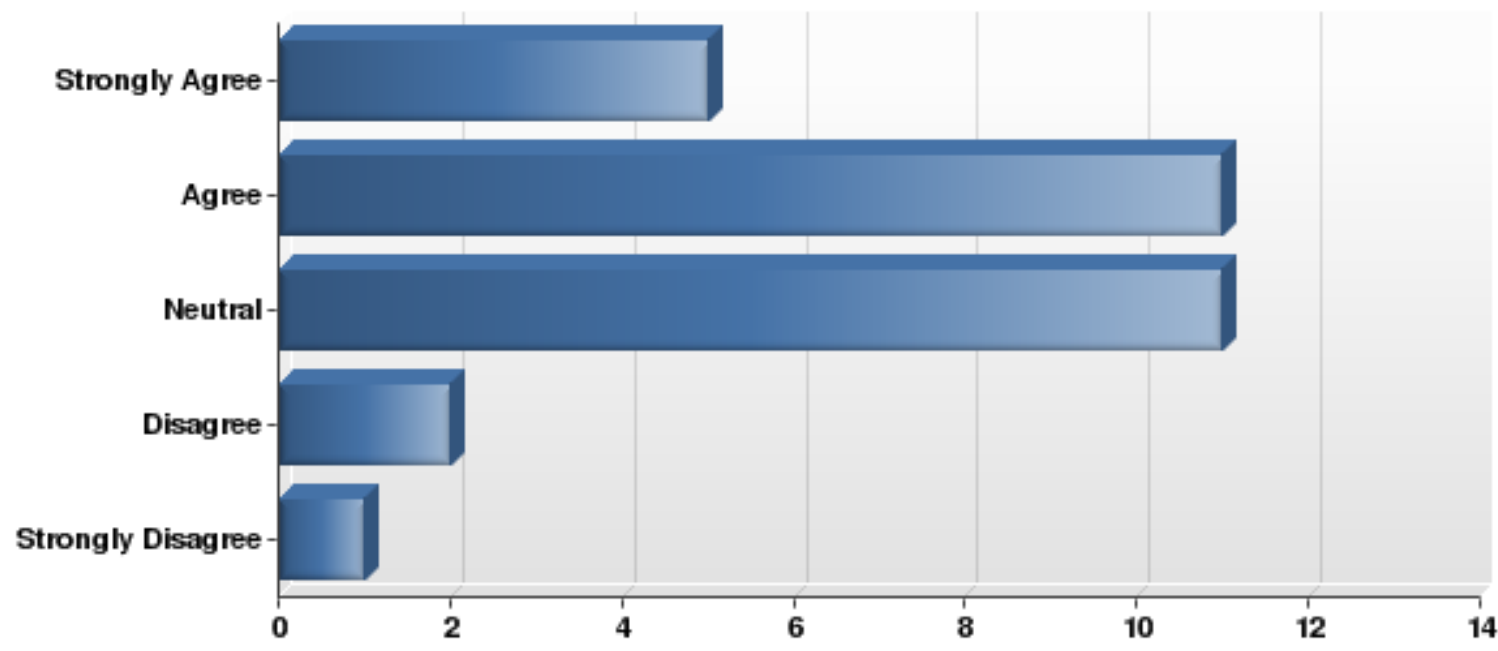




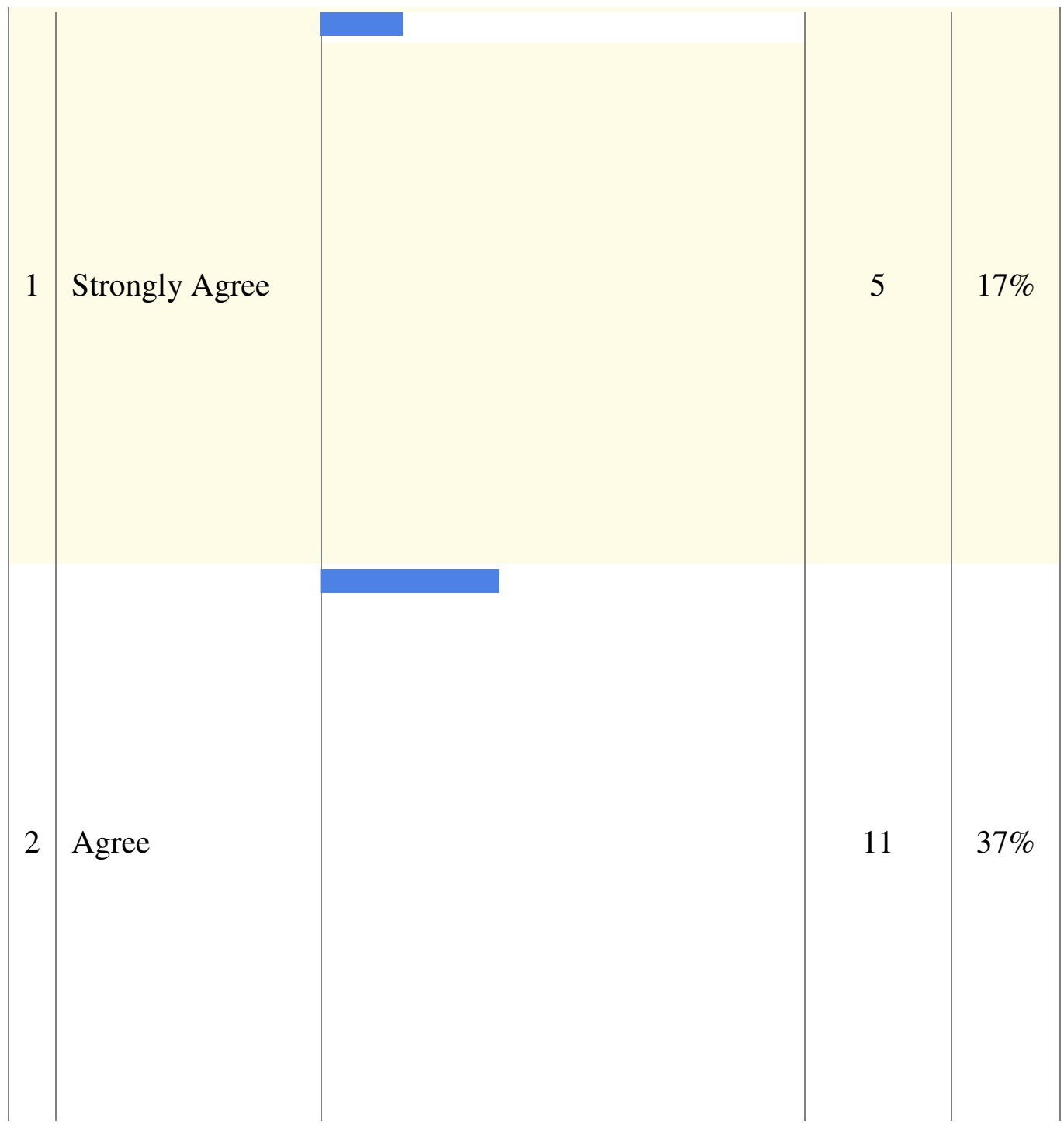




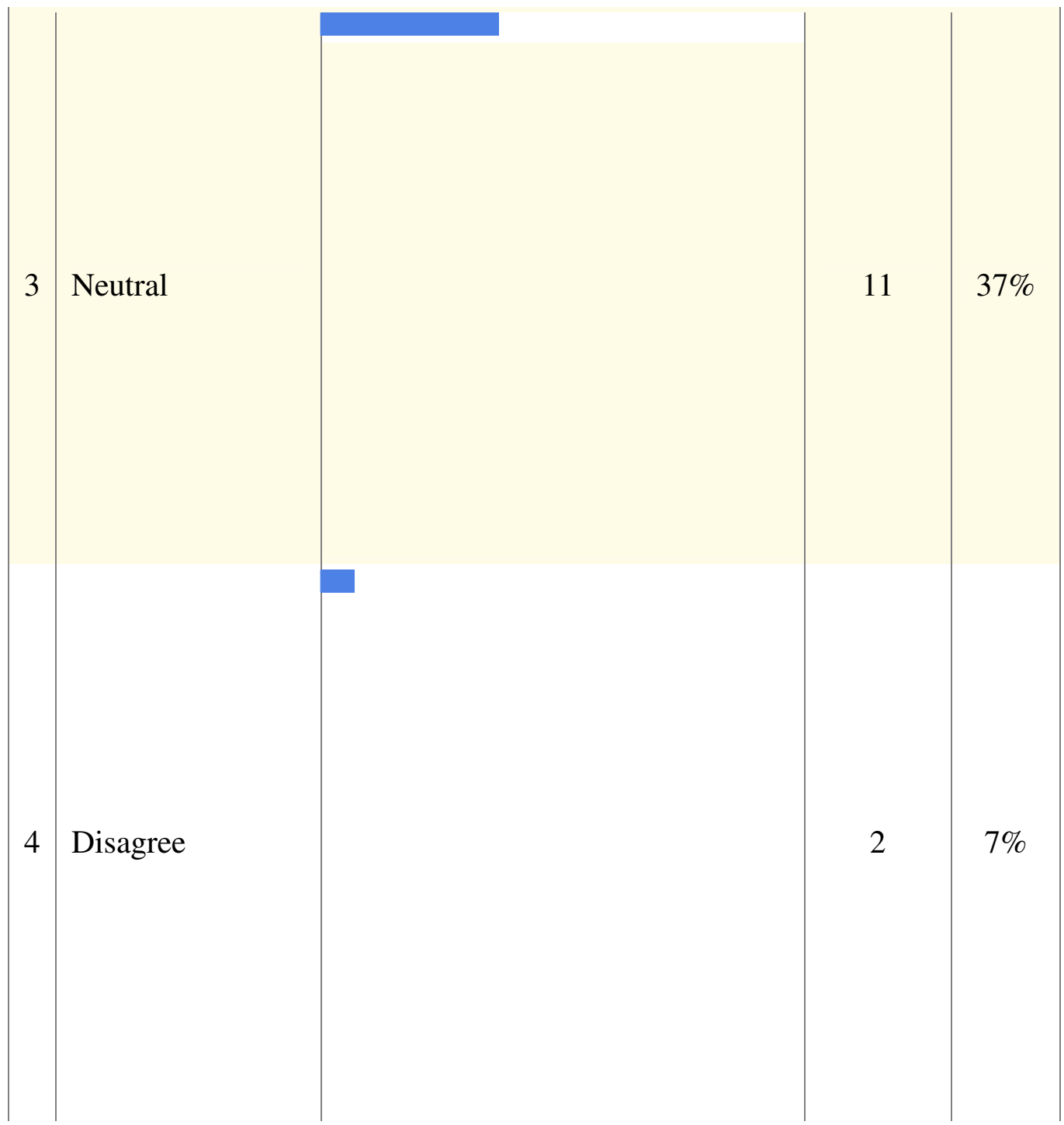




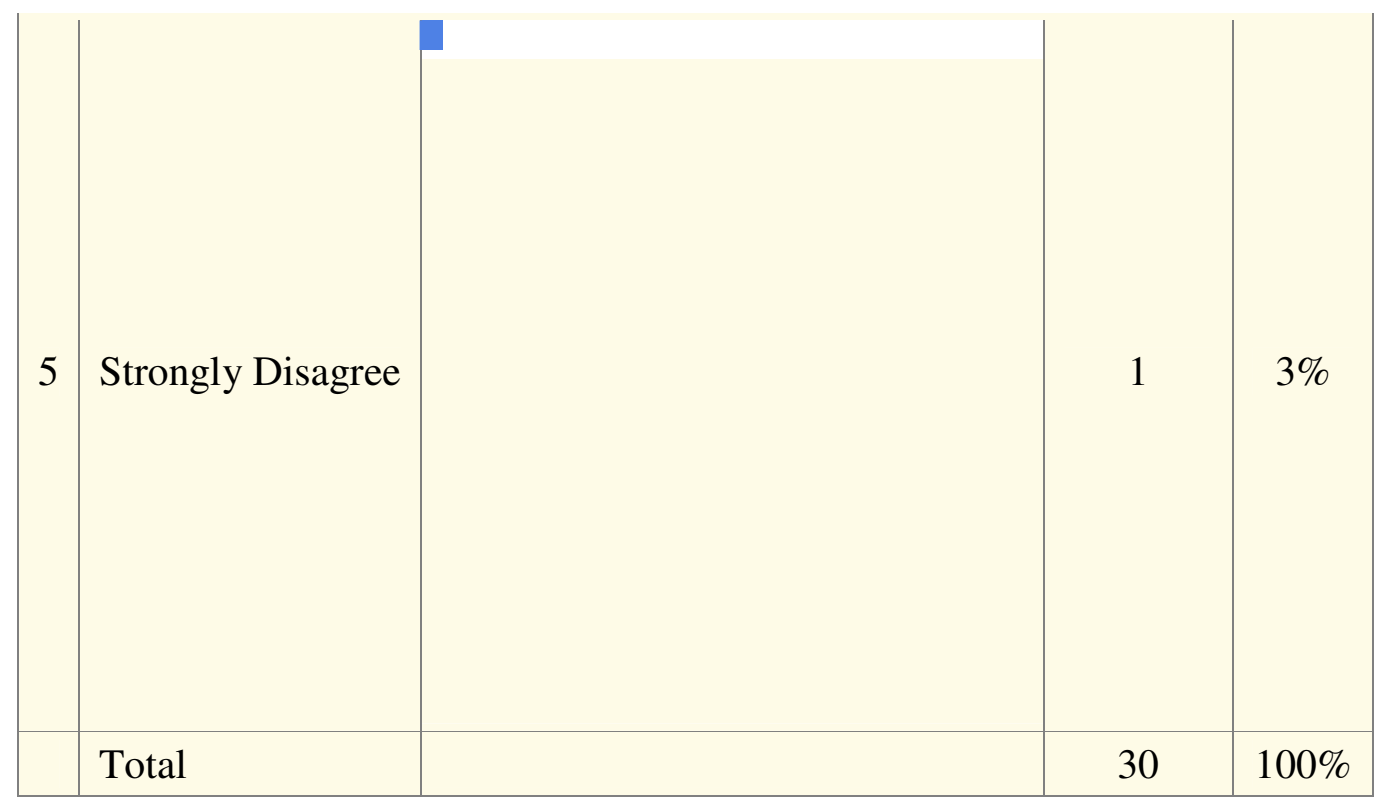

3. If you were asked to teach a history class at a near-by university this week, how would you feel (page 192)?

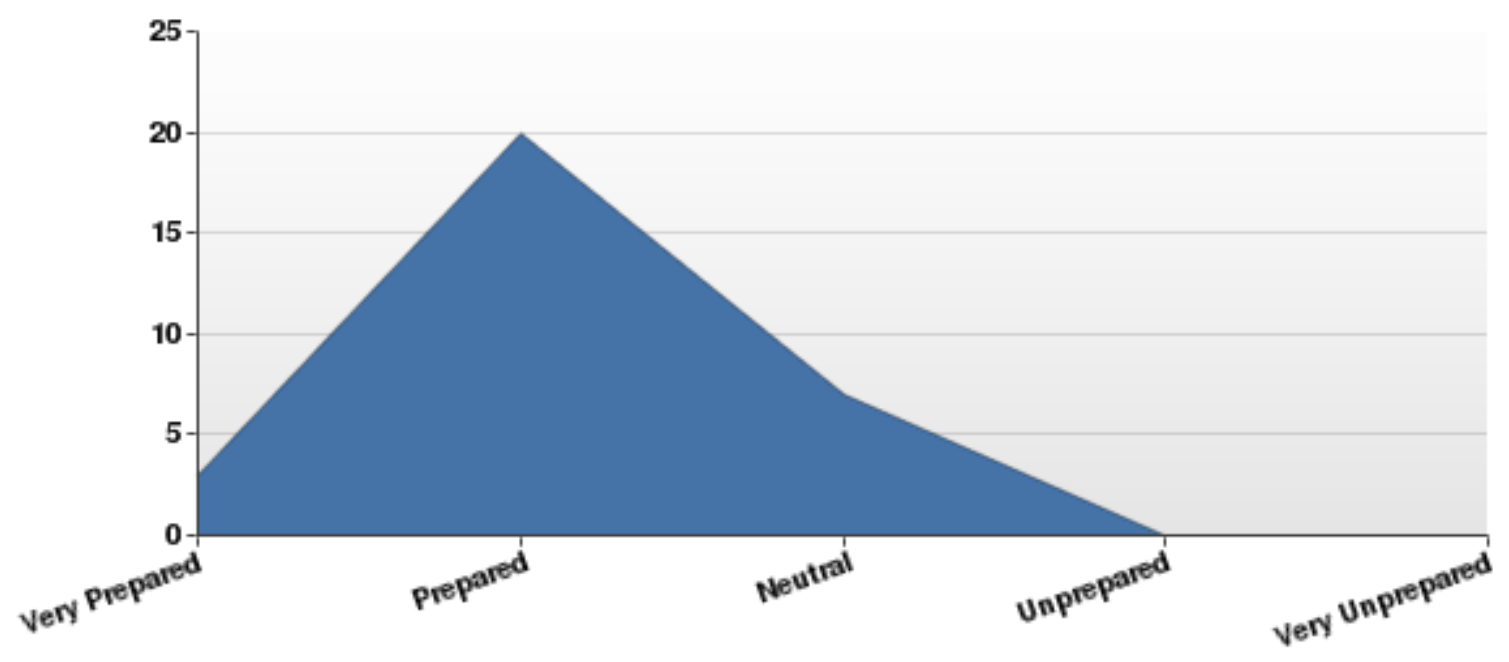




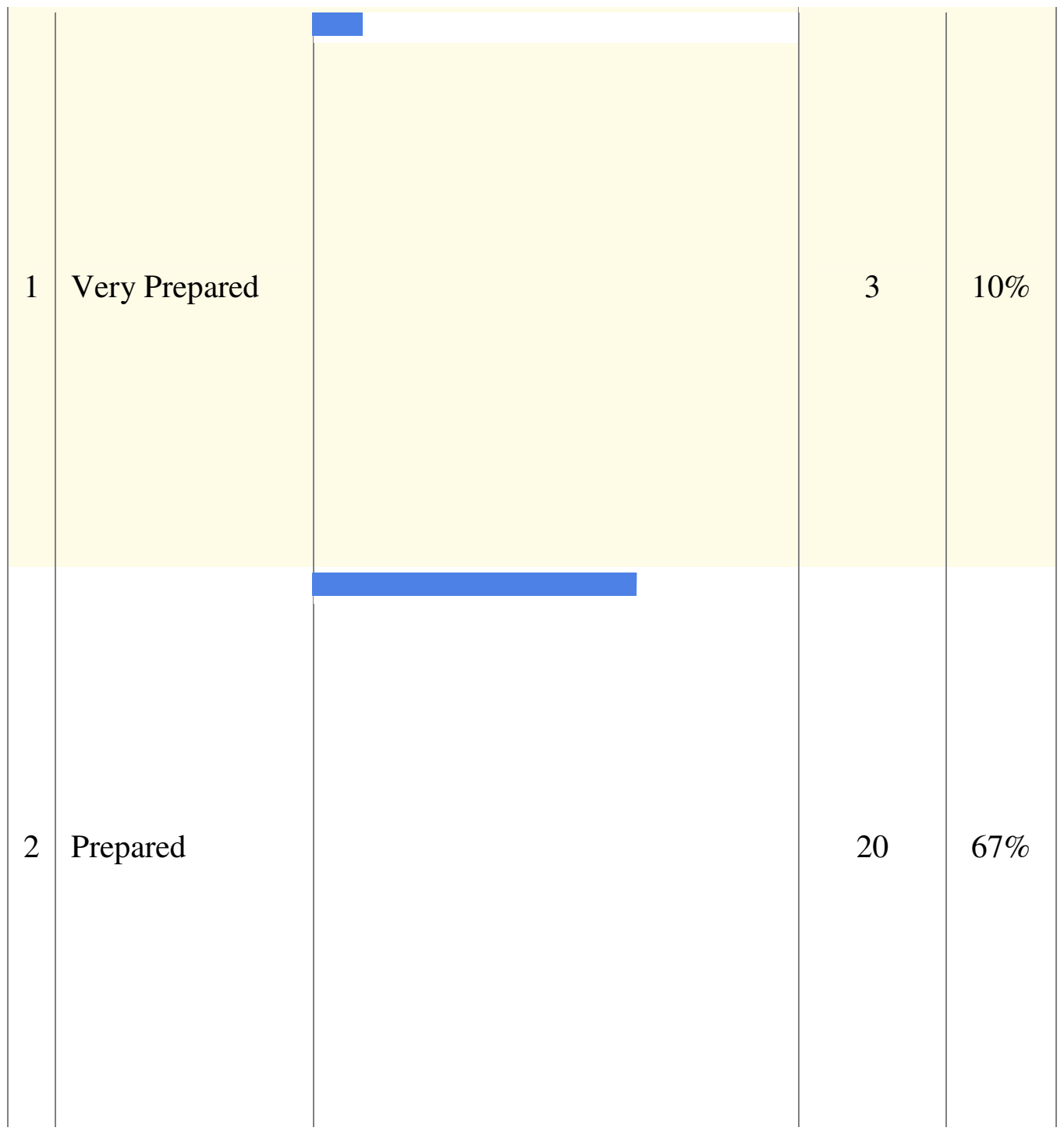




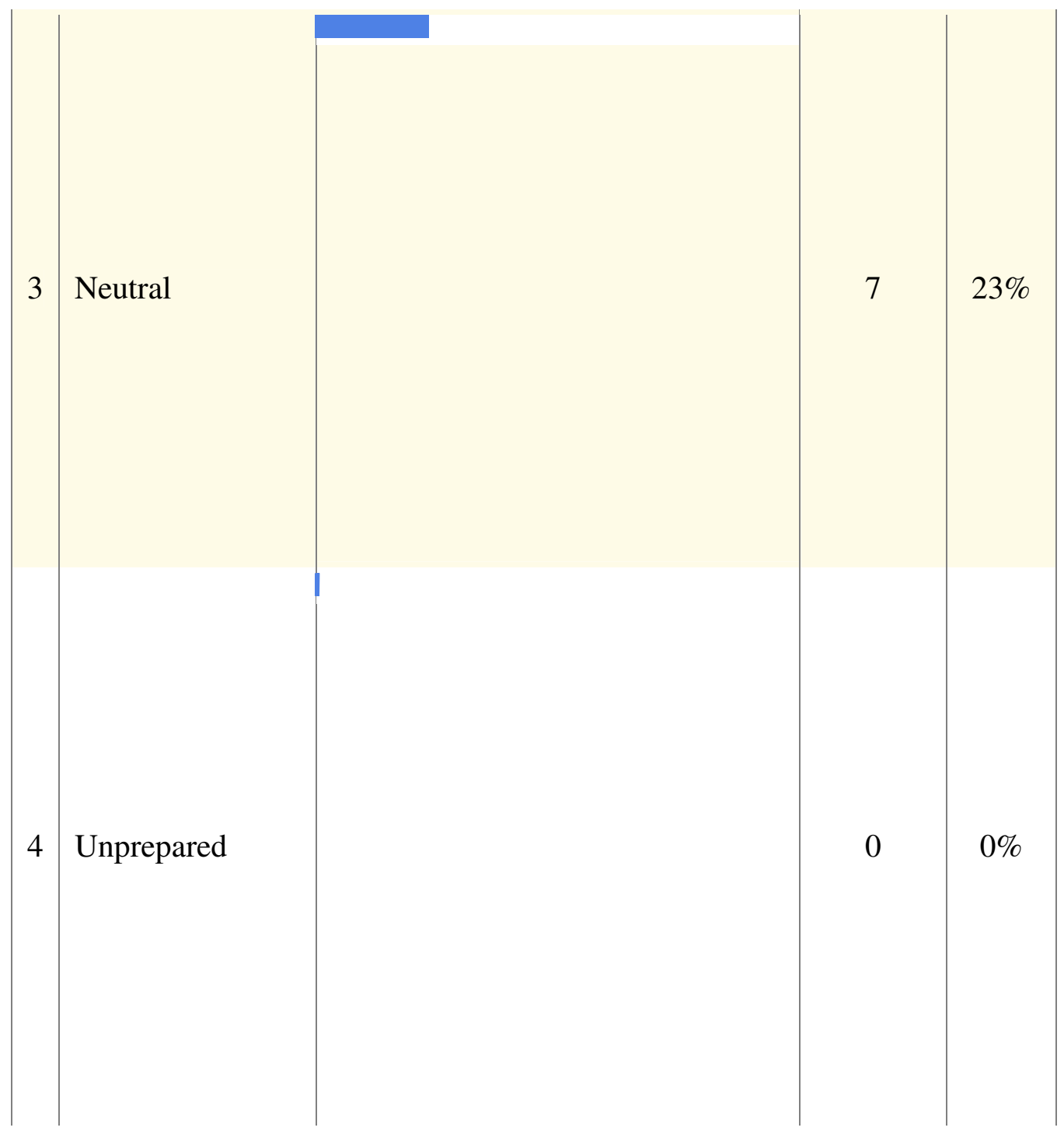




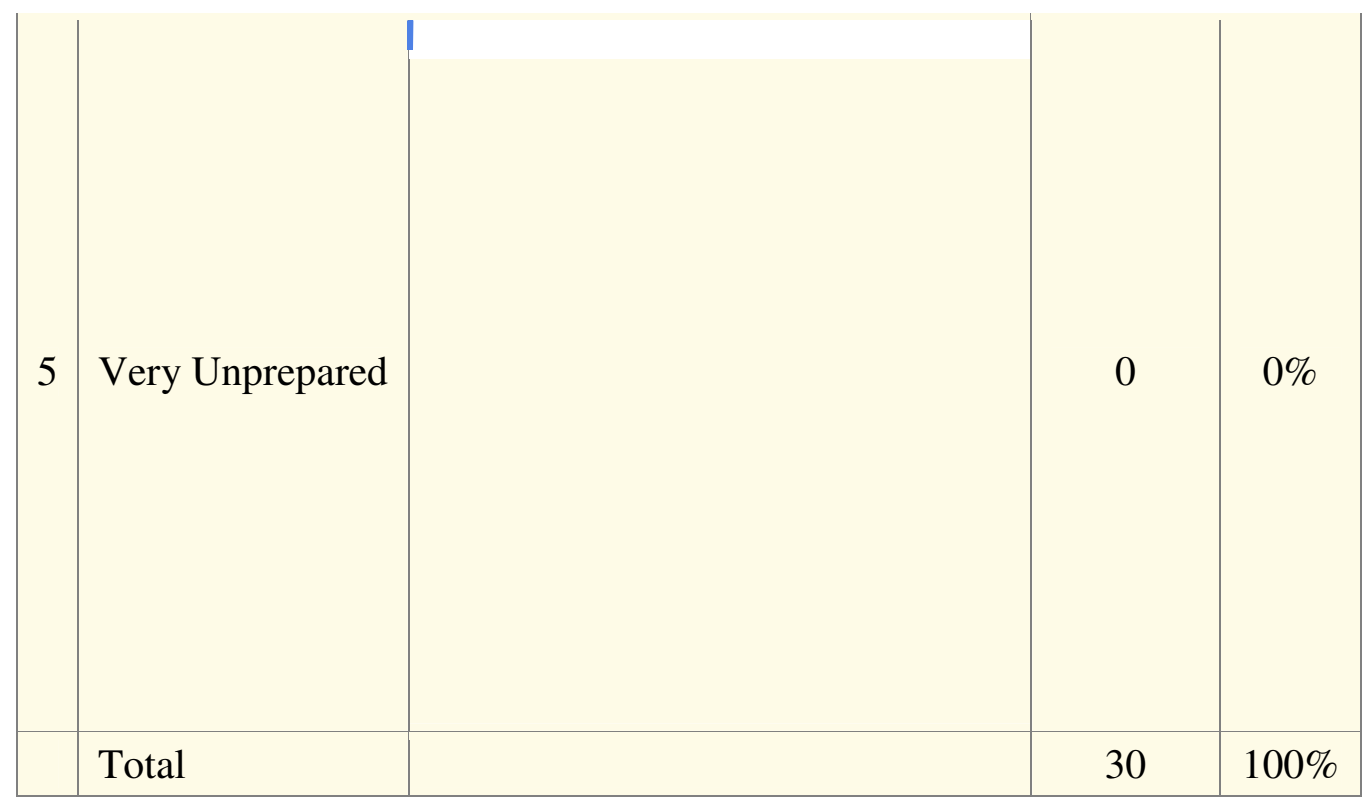

4. I know what universities are looking for in history teachers (page 193).

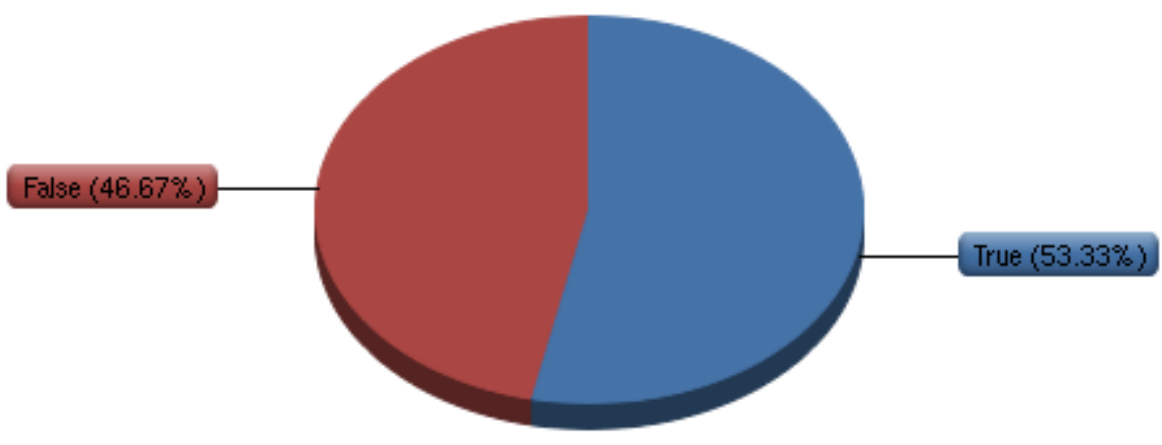




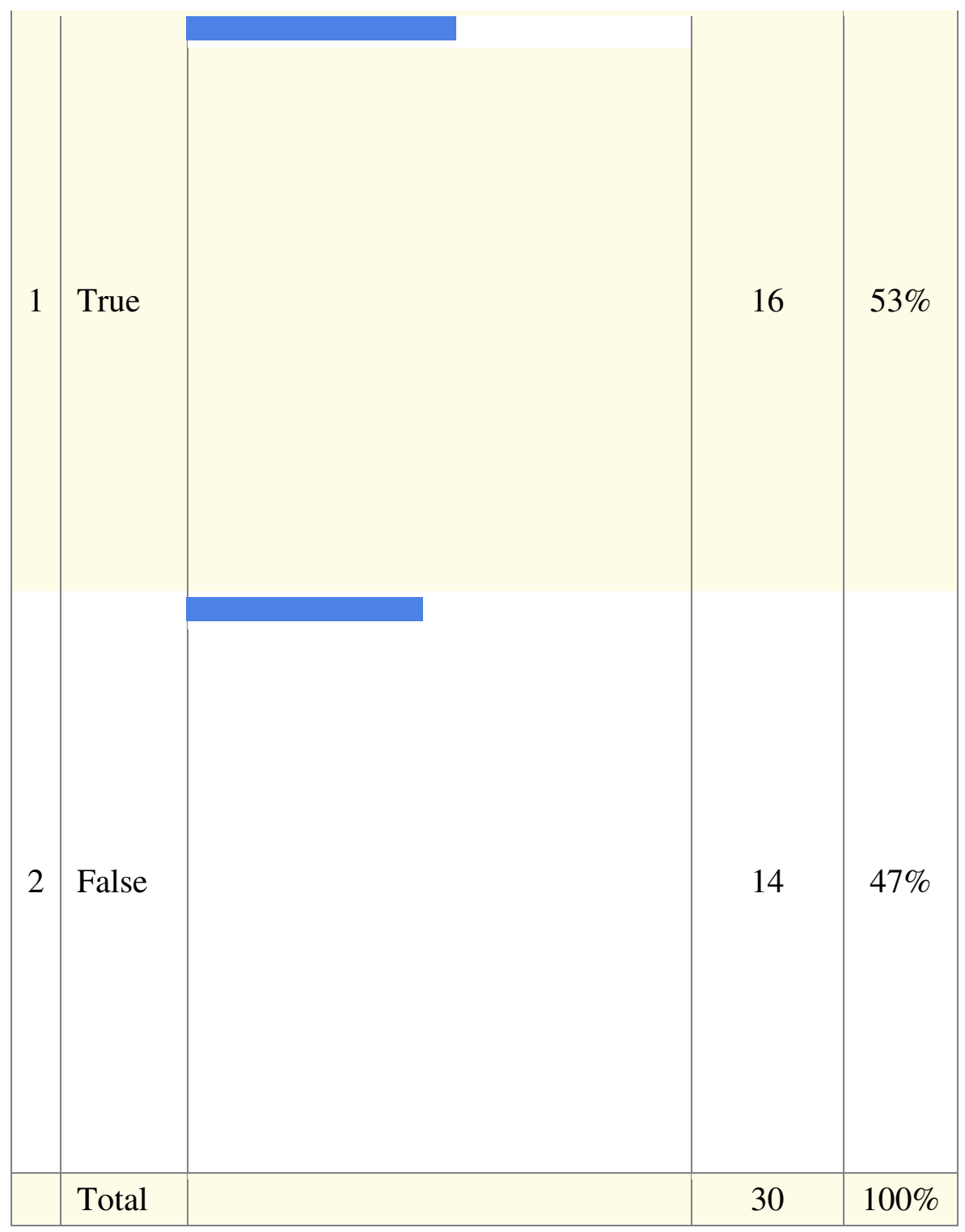

5. Upon graduation, I plan to pursue a teaching career (page 194). 

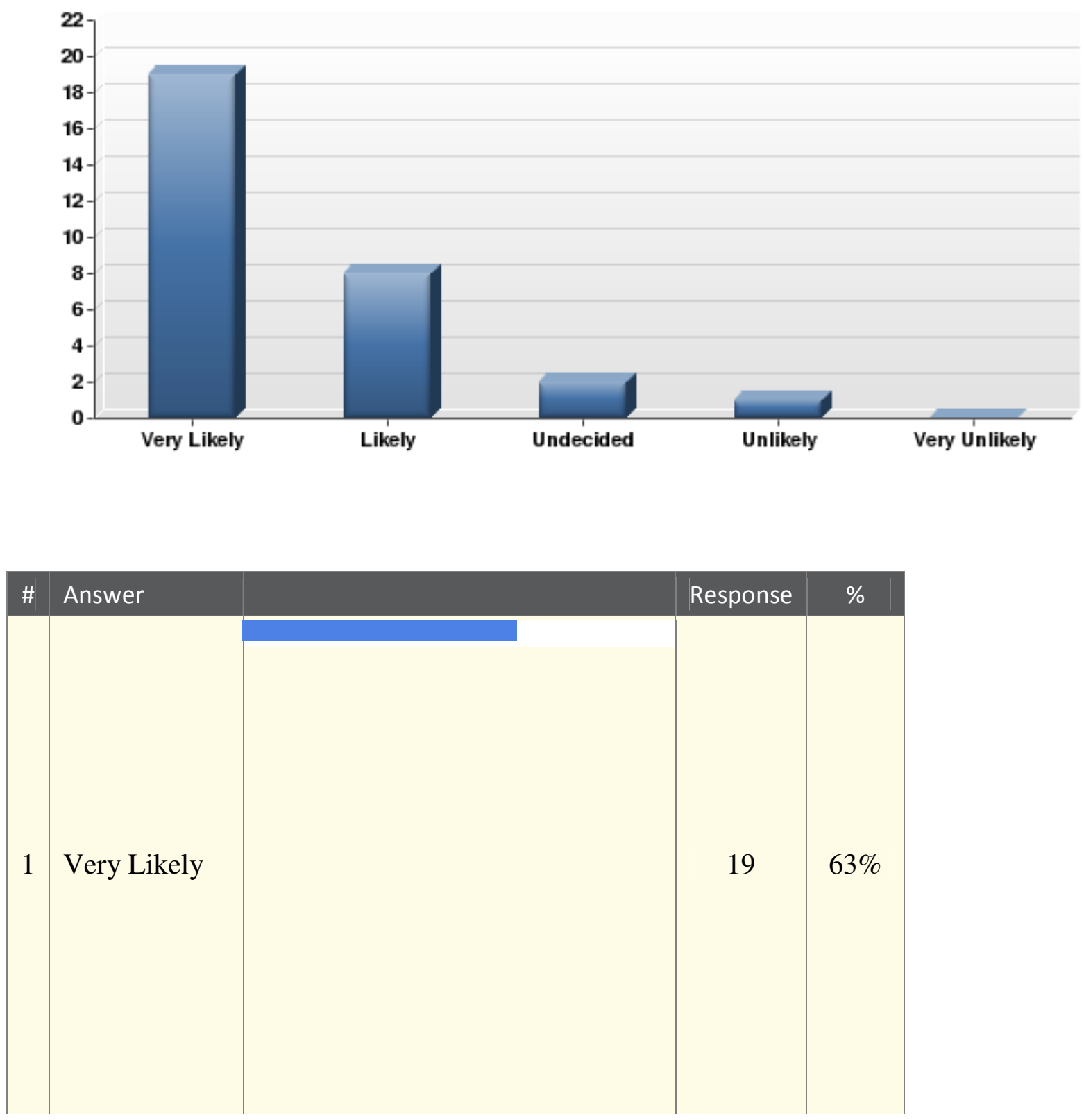


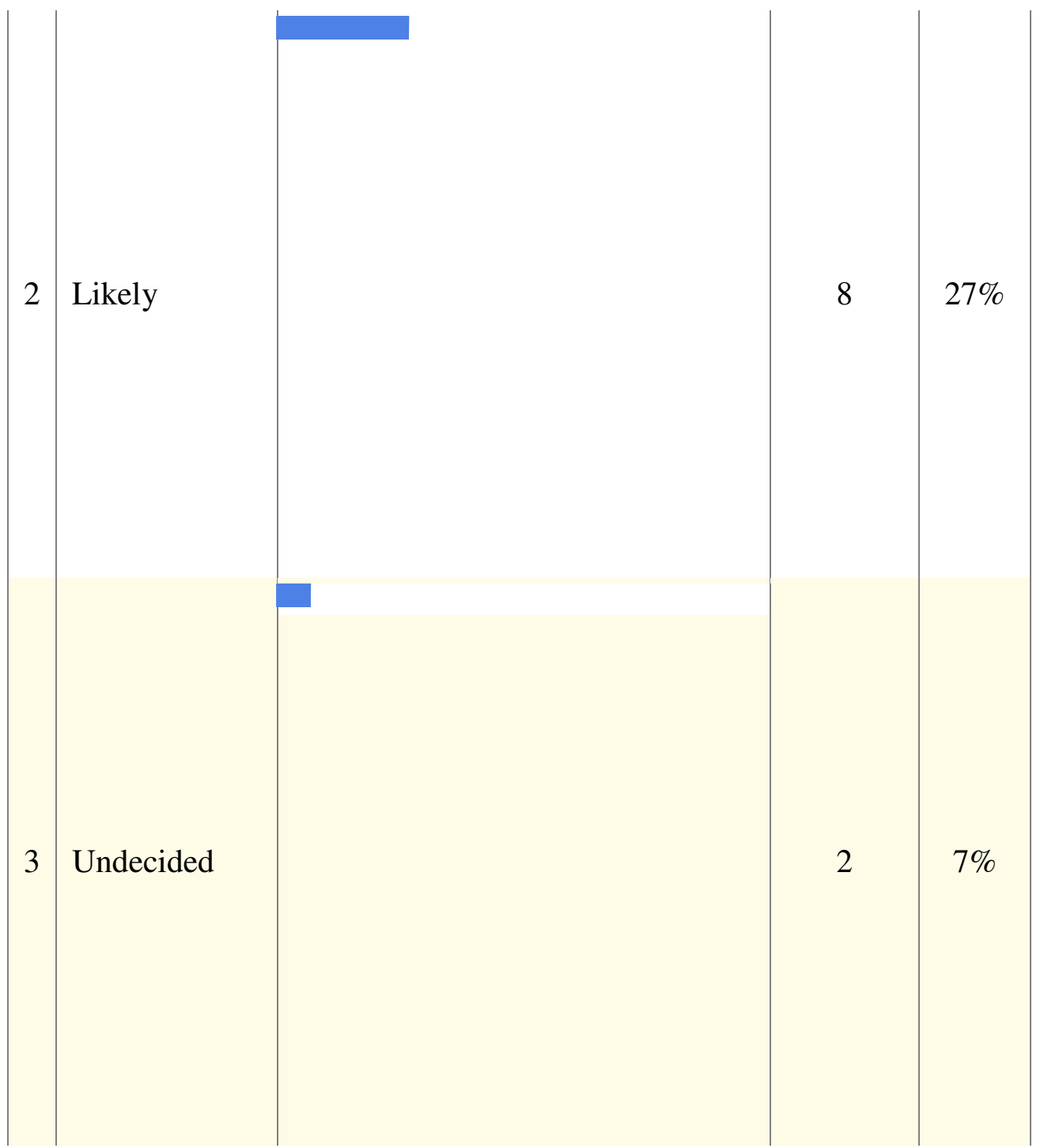




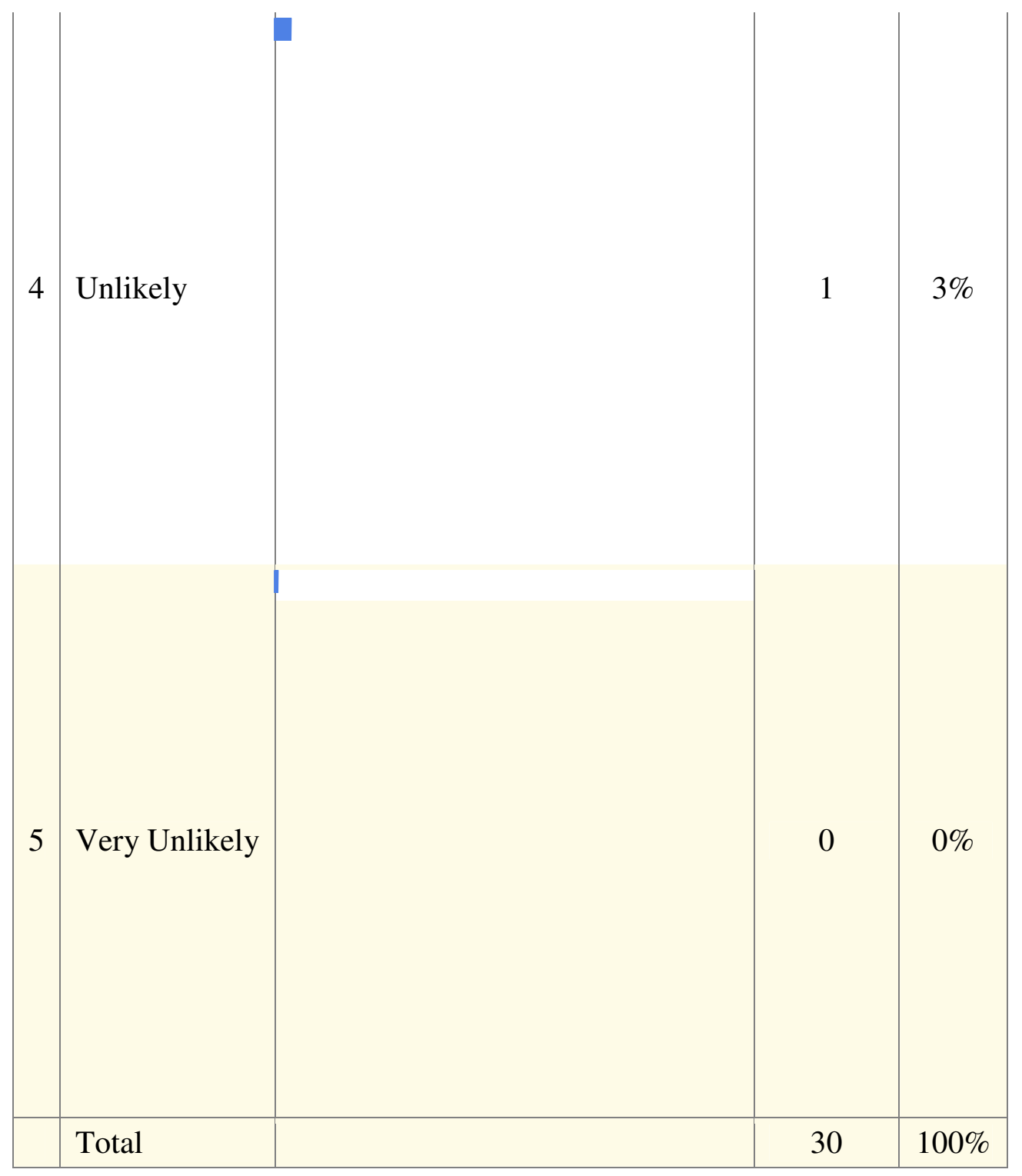

6. Upon graduation, I would feel confident in applying for a teaching position at a university (page 195). 

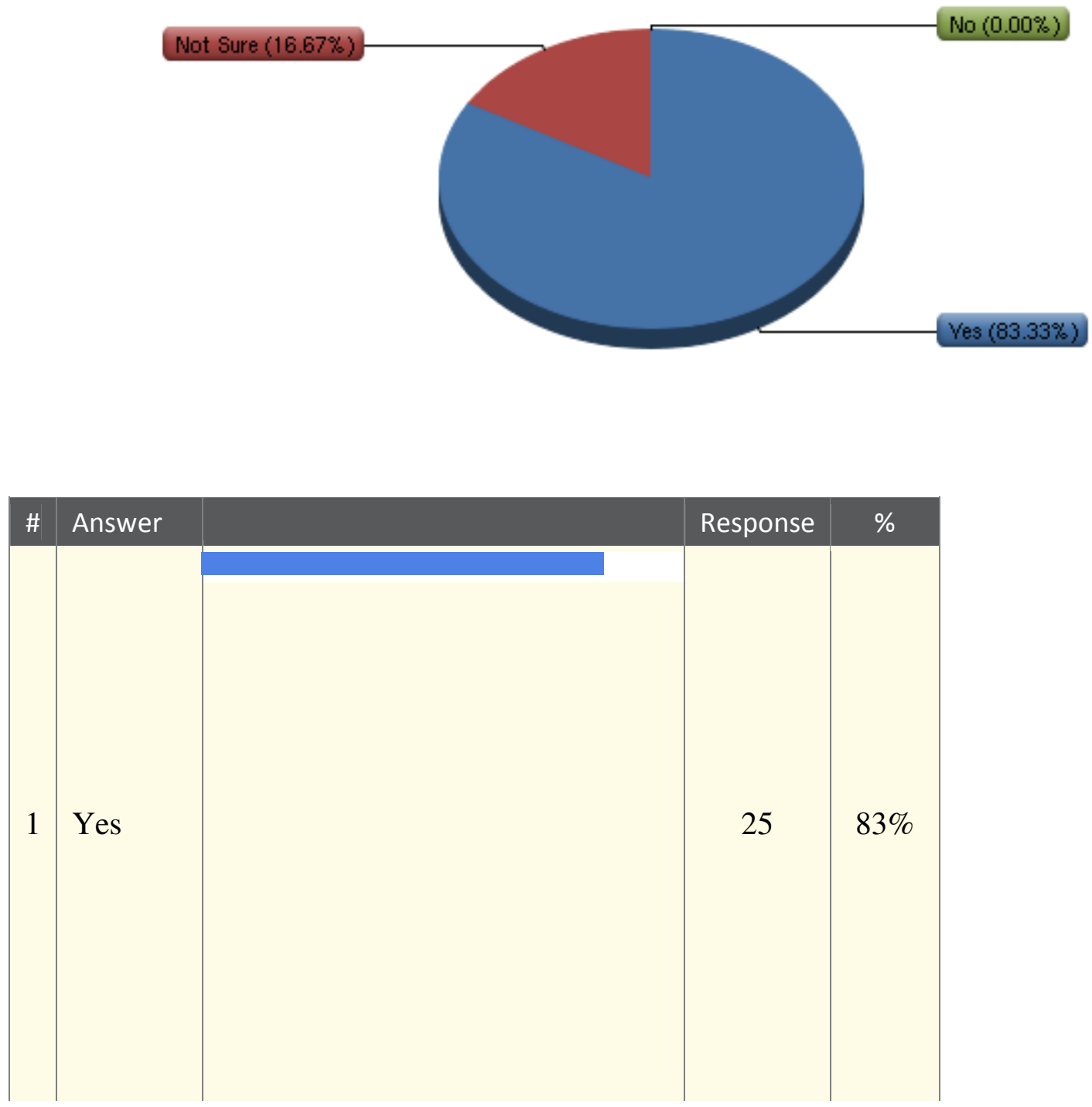


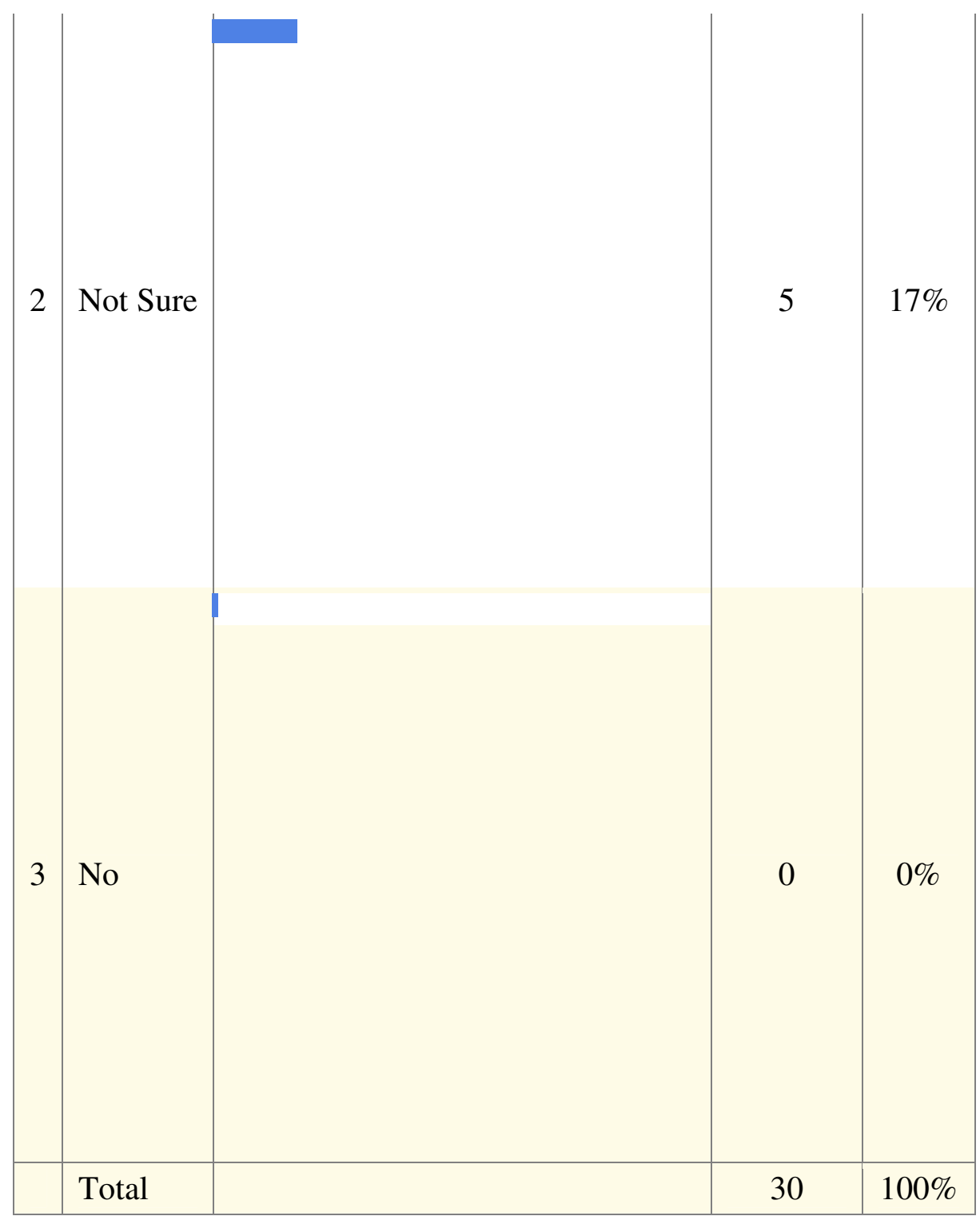

7. My graduate degree will prepare me to teach others what I have learned. 

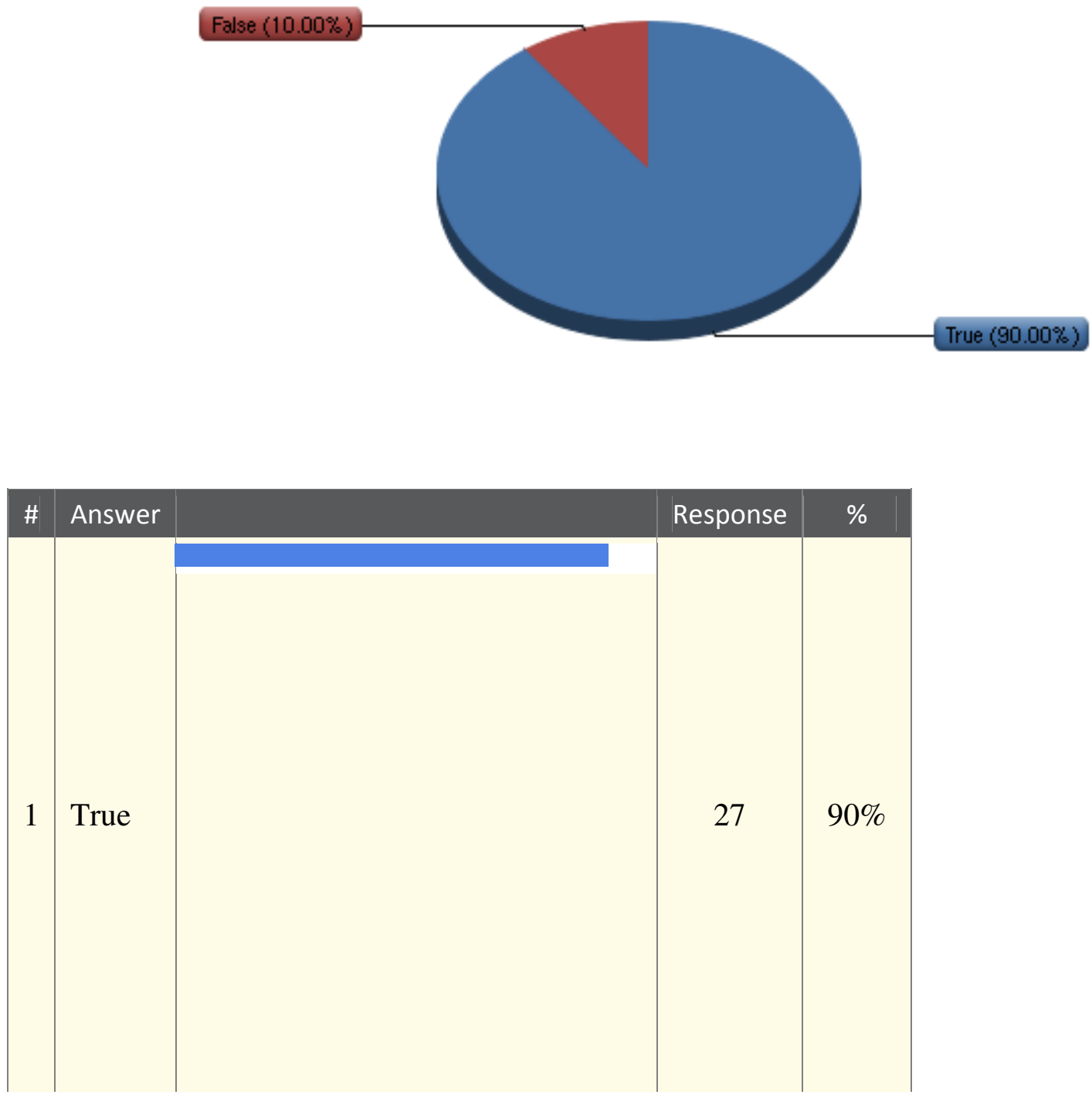


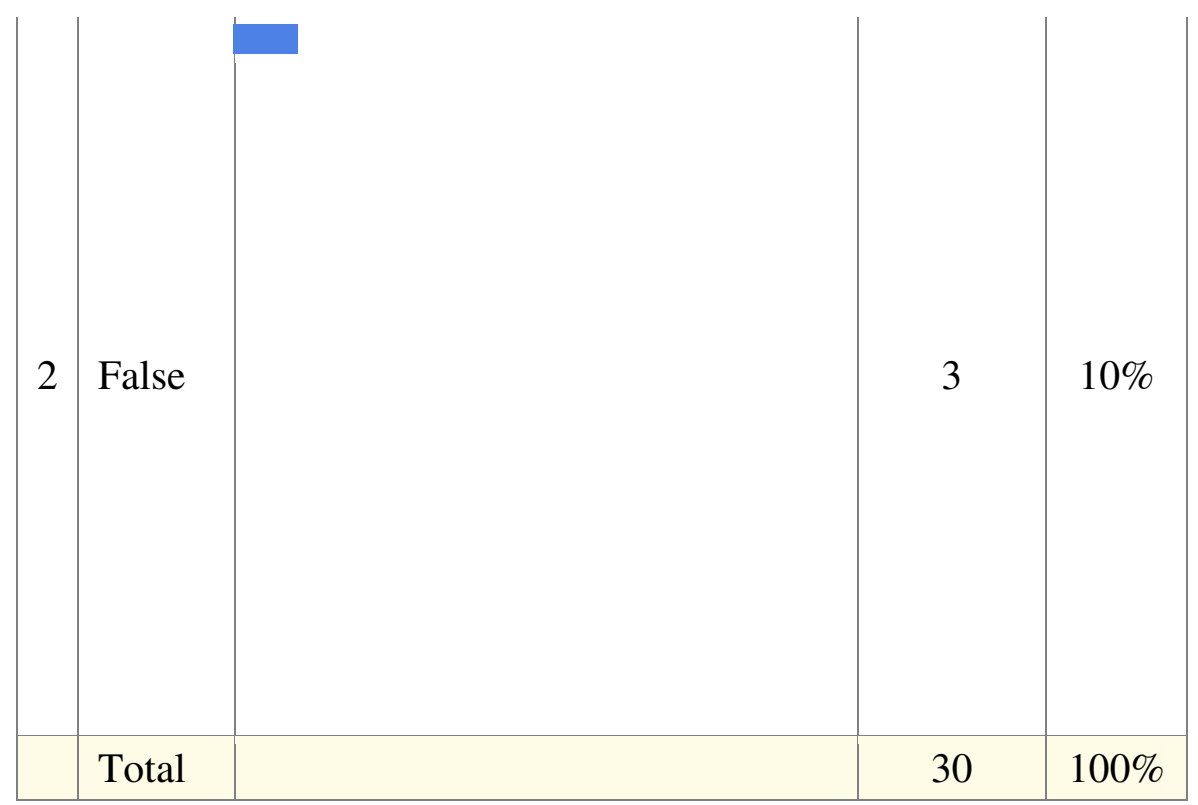

8. Upon graduation, I would feel comfortable working in a history department at a university (page 196).

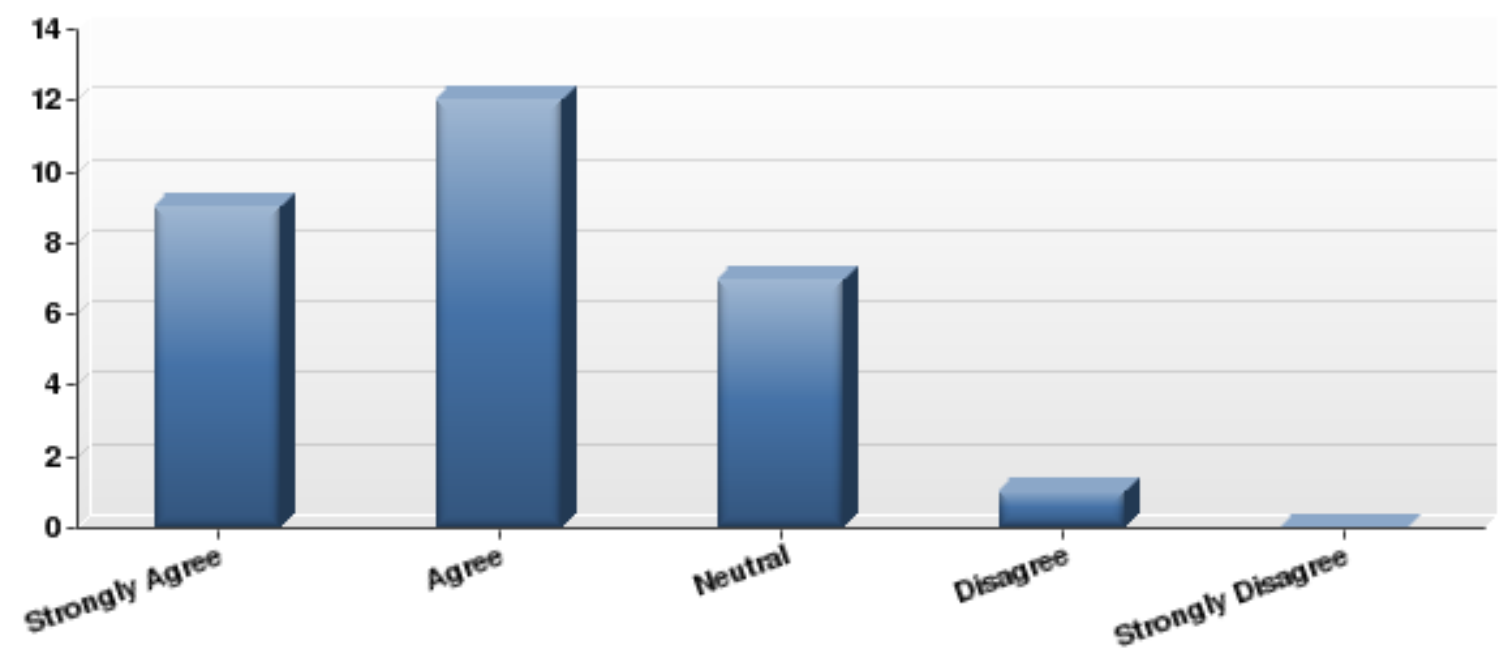




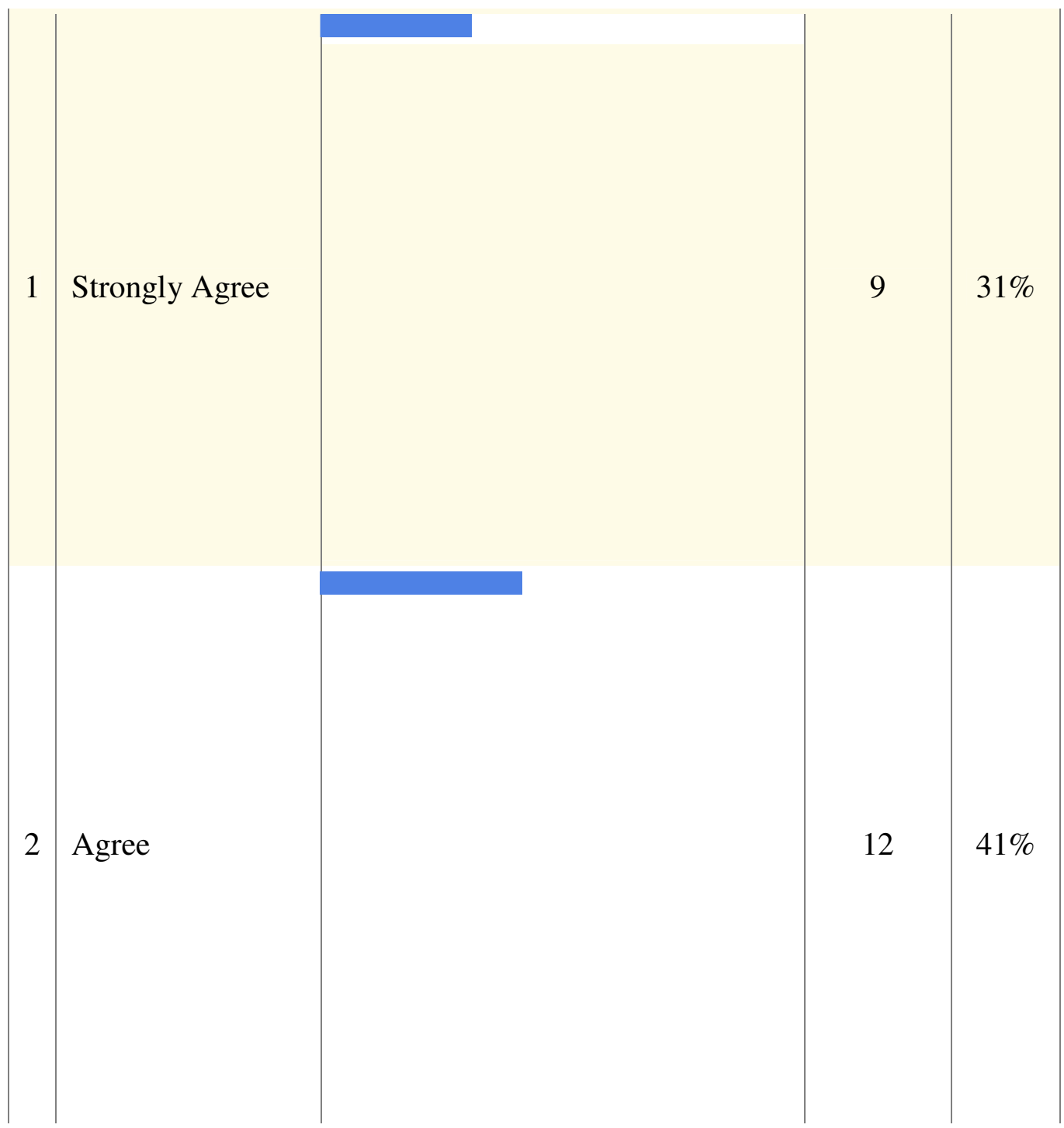




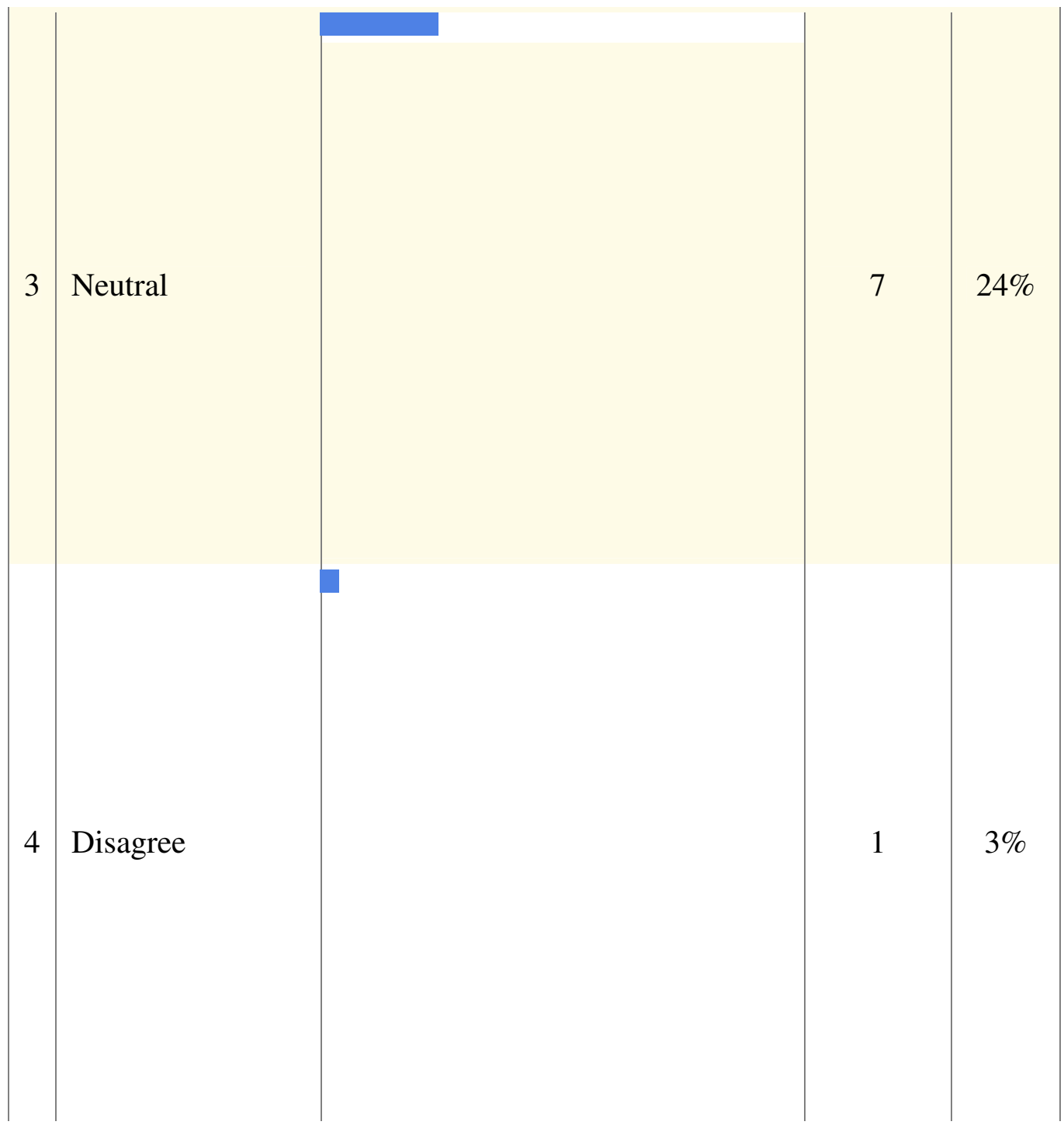




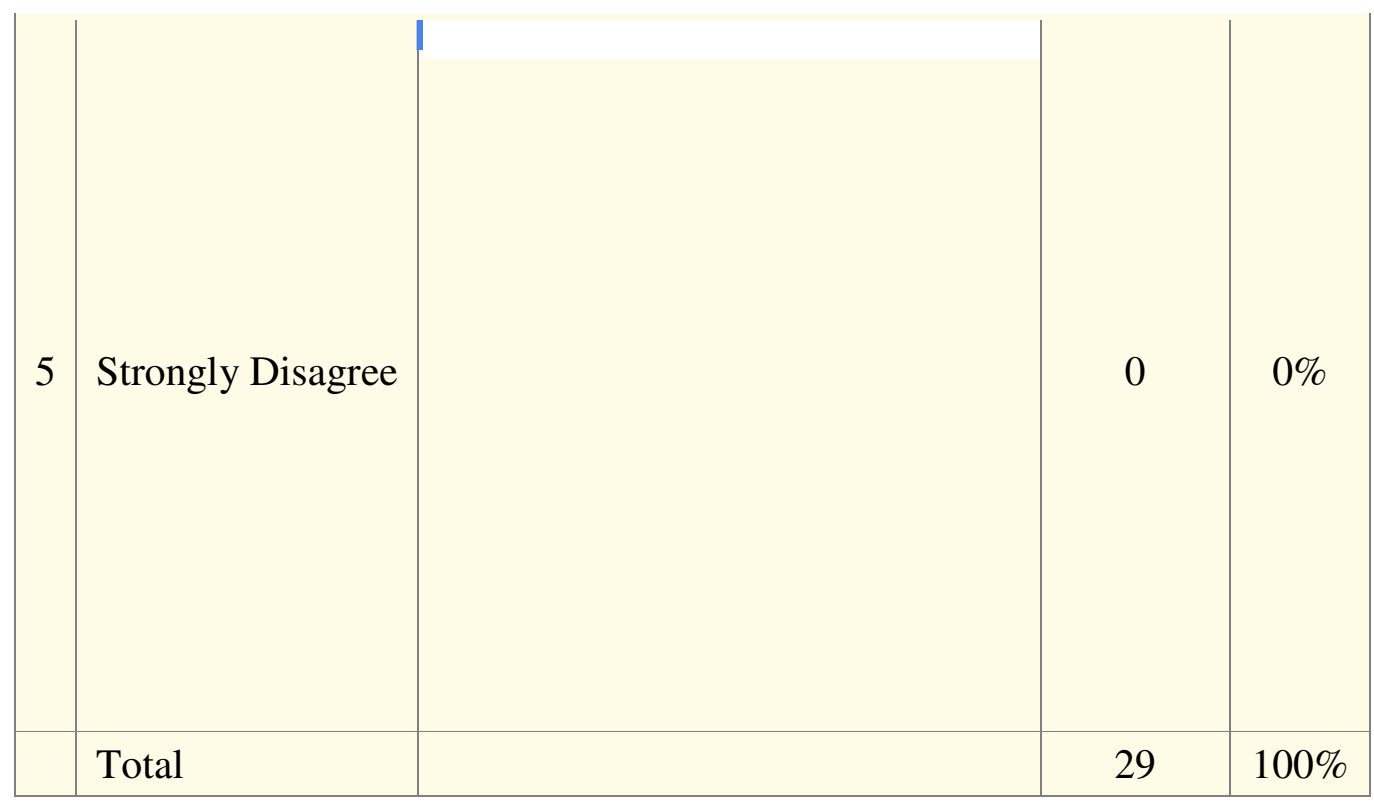

9. My graduate courses help to prepare me to teach history in my subject matter (page 197).

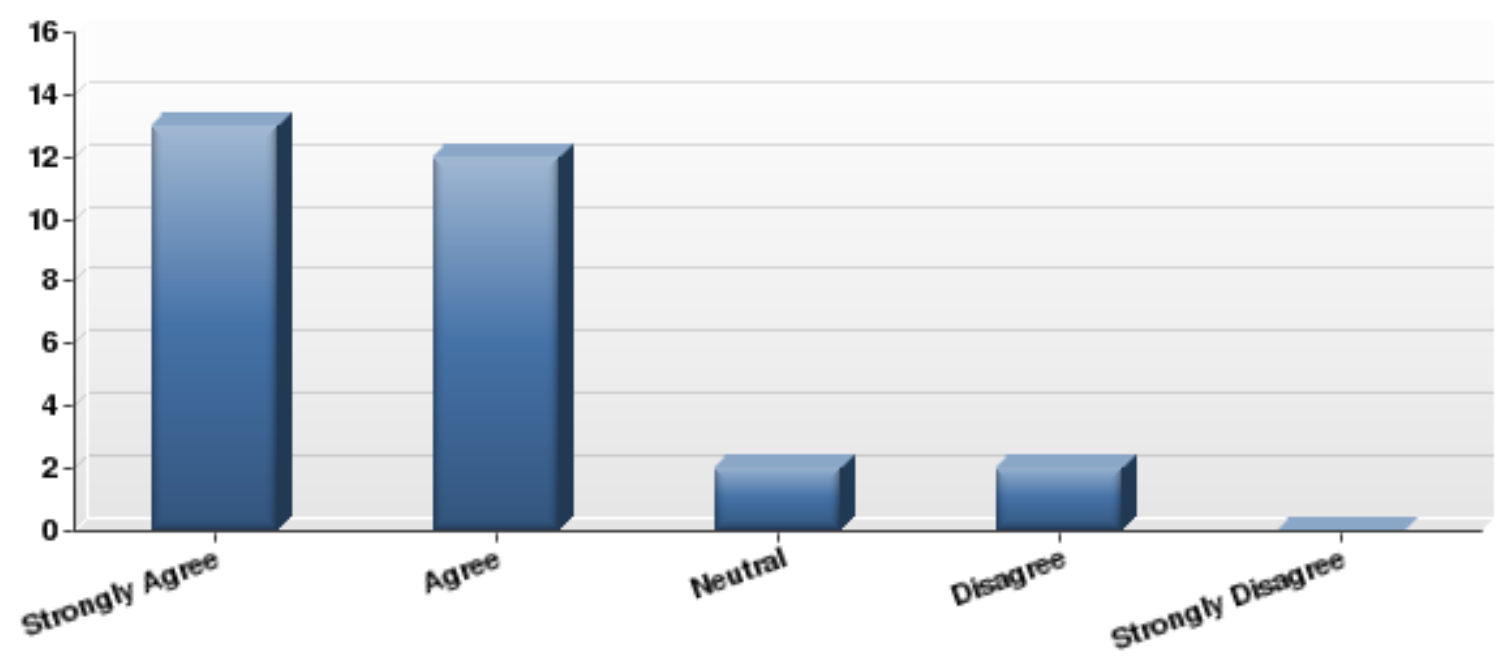




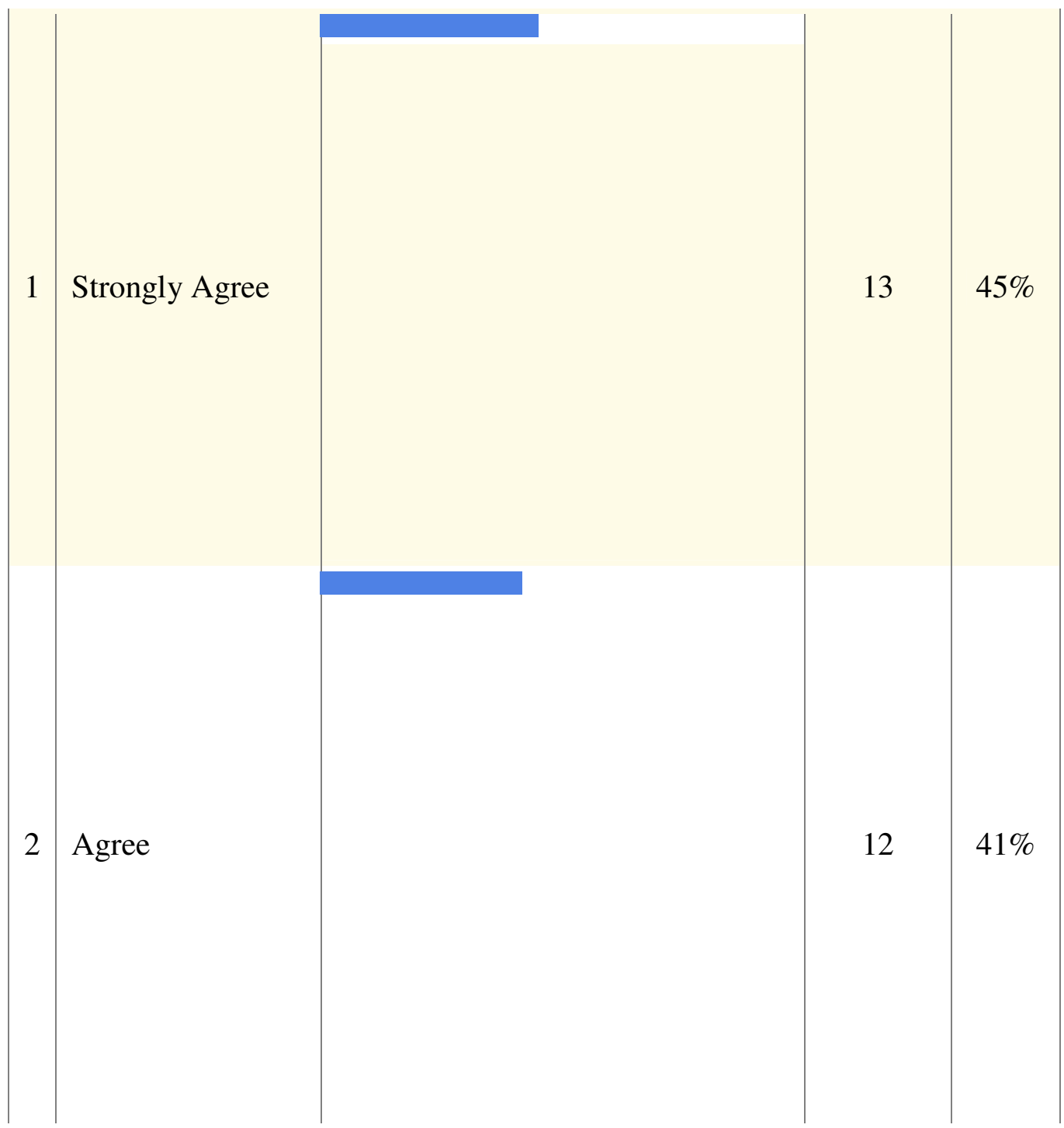




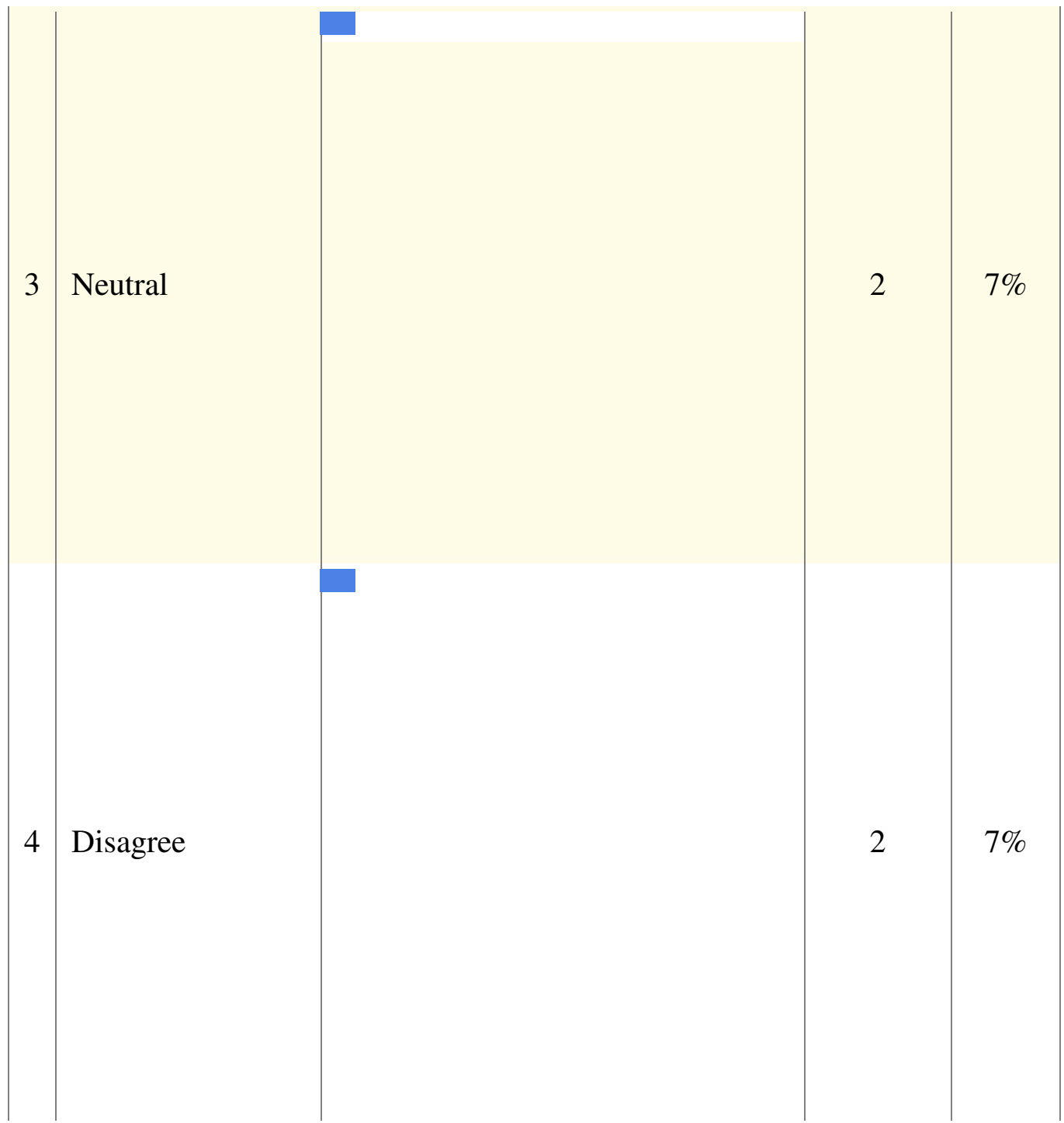




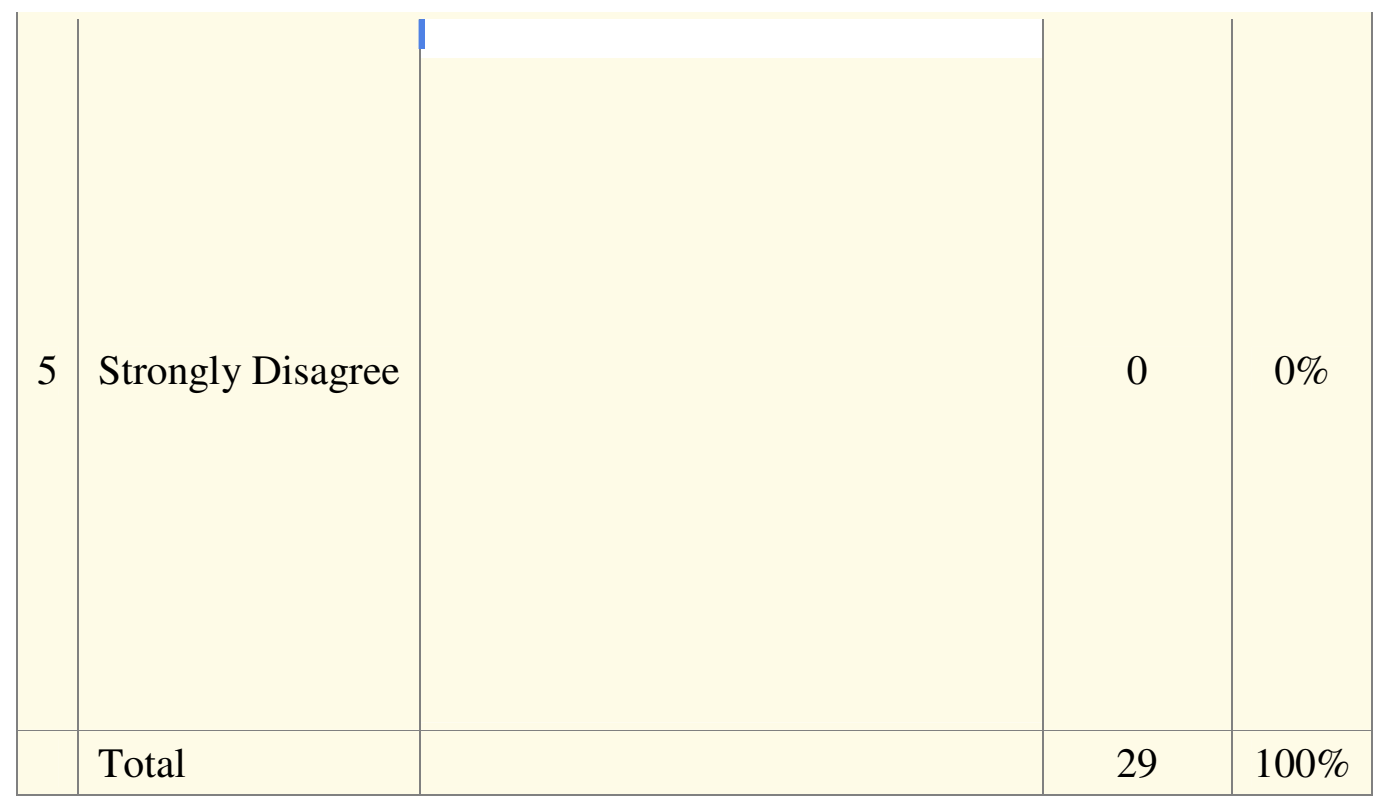

Results of Survey Administered to History Professors (page 198)

1. Upon completing an undergraduate degree, a history department should have adequately educated students to do the following: 


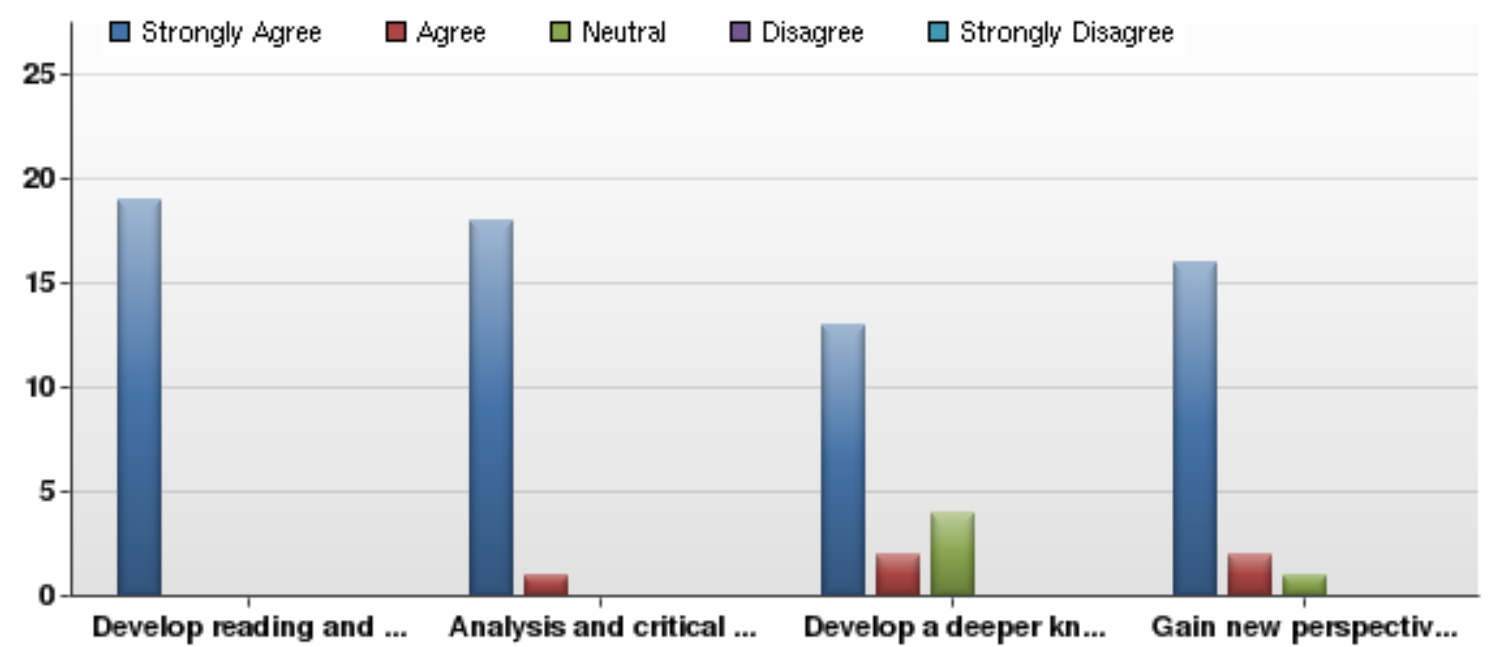

\begin{tabular}{|c|c|c|c|c|c|c|c|}
\hline \# & Question & $\begin{array}{l}\text { Strongly } \\
\text { Agree }\end{array}$ & Agree & Neutral & Disagree & $\begin{array}{l}\text { Strongly } \\
\text { Disagree }\end{array}$ & Responses \\
\hline 1 & $\begin{array}{l}\text { Develop reading and writing } \\
\text { skills. }\end{array}$ & 19 & 0 & 0 & 0 & 0 & 19 \\
\hline 2 & $\begin{array}{l}\text { Analysis and critical } \\
\text { thinking, and the ability to } \\
\text { assess conflicting } \\
\text { interpretations. }\end{array}$ & 18 & 1 & 0 & 0 & 0 & 19 \\
\hline 3 & $\begin{array}{l}\text { Develop a deeper knowledge } \\
\text { of the history of a particular } \\
\text { time and/or place. }\end{array}$ & 13 & 2 & 4 & 0 & 0 & 19 \\
\hline 4 & $\begin{array}{l}\text { Gain new perspectives by } \\
\text { understanding past cultures. }\end{array}$ & 16 & 2 & 1 & 0 & 0 & 19 \\
\hline
\end{tabular}

\begin{tabular}{|l|c|c|c|c|}
\hline Statistic & $\begin{array}{c}\text { Develop } \\
\text { reading and } \\
\text { writing } \\
\text { skills. }\end{array}$ & $\begin{array}{c}\text { Analysis and critical } \\
\text { thinking, and the ability to } \\
\text { assess conflicting } \\
\text { interpretations. }\end{array}$ & $\begin{array}{c}\text { Develop a deeper } \\
\text { knowledge of the } \\
\text { history of a particular } \\
\text { time and/or place. }\end{array}$ & $\begin{array}{c}\text { Gain new } \\
\text { perspectives by } \\
\text { understanding past } \\
\text { cultures. }\end{array}$ \\
\hline $\begin{array}{l}\text { Total } \\
\text { Responses }\end{array}$ & 19 & 19 & 19 & 19 \\
\hline
\end{tabular}

\section{Please rank the following items from 1-5 in order of importance in your teaching undergraduate students (page 199). (1 being the most important, 2 as next important...5 as least important.)}




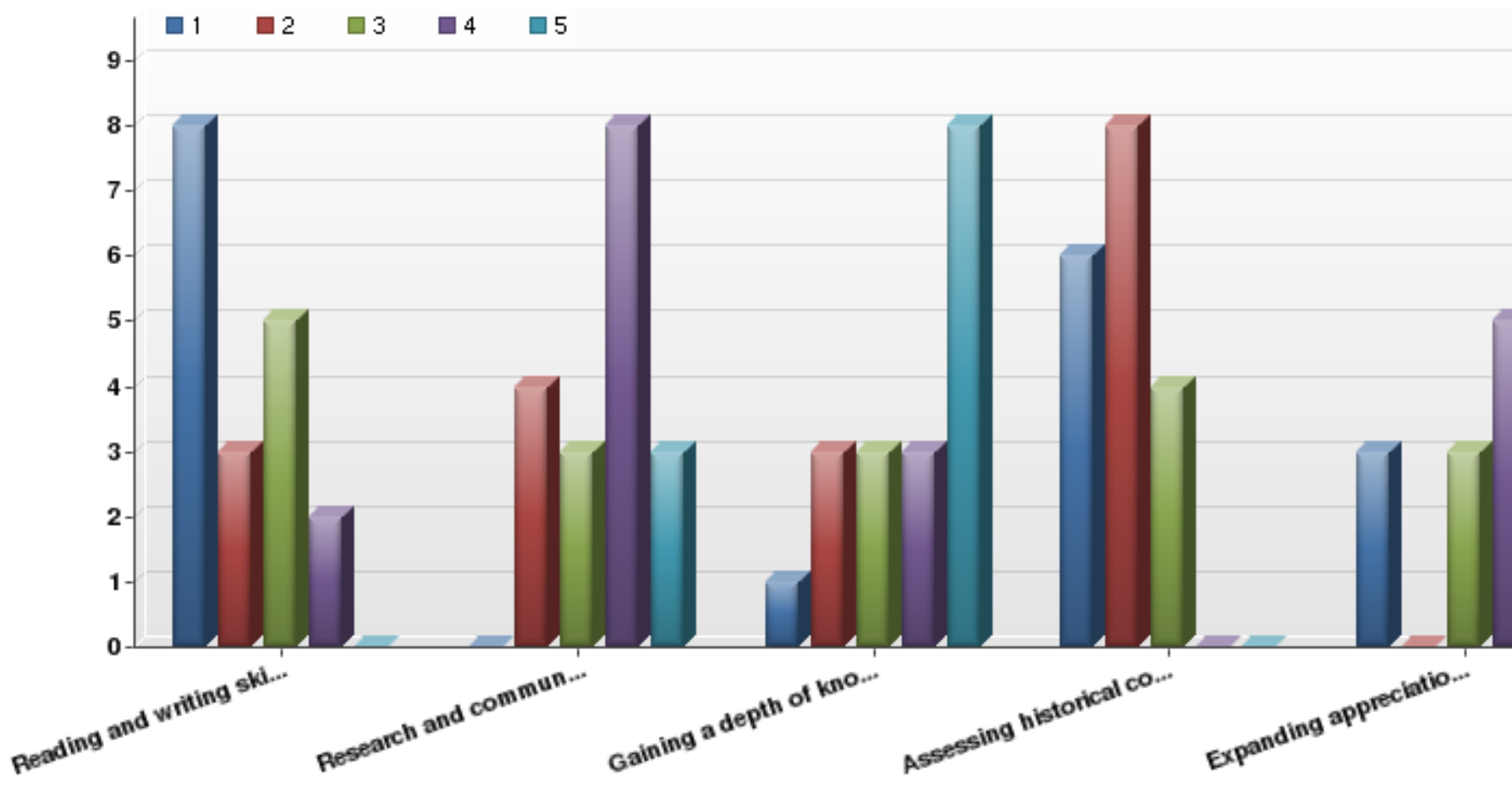

\begin{tabular}{|l|l|l|l|l|l|l|c|}
\hline \# & Answer & 1 & 2 & 3 & 4 & 5 & Responses \\
\hline 1 & Reading and writing skills & 8 & 3 & 5 & 2 & 0 & 18 \\
2 & 0 & 4 & 3 & 8 & 3 & 18 \\
3 & $\begin{array}{l}\text { Research and communication skills } \\
\text { Gaining a depth of knowledge of a particular time- } \\
\text { period }\end{array}$ & 1 & 3 & 3 & 3 & 8 & 18 \\
4 & $\begin{array}{l}\text { Assessing historical context and analyzing historical } \\
\text { documents }\end{array}$ & 6 & 8 & 4 & 0 & 0 & 18 \\
\hline 5 & 3 & 0 & 3 & 5 & 7 & 18 \\
\hline $\begin{array}{l}\text { Expanding appreciation and understanding for past } \\
\text { cultures. }\end{array}$ & 18 & 18 & 18 & 18 & 18 & \\
\hline & Total & & & & \\
\hline
\end{tabular}

\section{In your opinion, is there a skill that should be taught to undergraduate history majors, but has been neglected in the required course work (page 200)?}

\section{Text Response}

The undergraduate curriculum at Chicago is not coherently organized, so the students don't 
develop a systematica knowledge base.

It is all about the writing--more writing!

In my experience, many students come to college assuming that all necessary knowledge is included in textbooks, and learning is a matter of absorbing what they say. Teaching students to READ critically (as a crucial component of critical thinking) is one of the biggest challenges in dealing with undergraduates today--and one that is often not reinforced in many of their undergraduate courses.

perhaps skills in public history.

Learning to assess whether a secondary source is useful and reliable.

Reading comprehension is a neglected area of skill development in history and other courses. With that skill, students can then move to the development of analytical and writing skills. I find the skills listed above to be inter-related and, therefore, not easily ranked.

Not at my institution. I cannot speak of other institutions.

Imagination and curiosity

The distinction between narration and explanation.

Structural issues play a huge role, as does the level of preparation and ability students bring to college work. In general, more attention to making clear and compelling arguments using evidence, and critically reading and understanding documents (in historical and social/cultural context) are essential skills not easily taught in large classes of not terribly motivated students (page 201).

Not so much a skill as greater emphais on traditional fields of political, diplomatic, social, and military history.Although a European historian, I find it appalling that so few undergraduates take courses on the American Revolution, i.e. the founding of the Republic and the Civil War.

\section{From one to ten, how would you rate your institution's scholarly level in comparison to other Universities nation-wide? (1 being the best)}



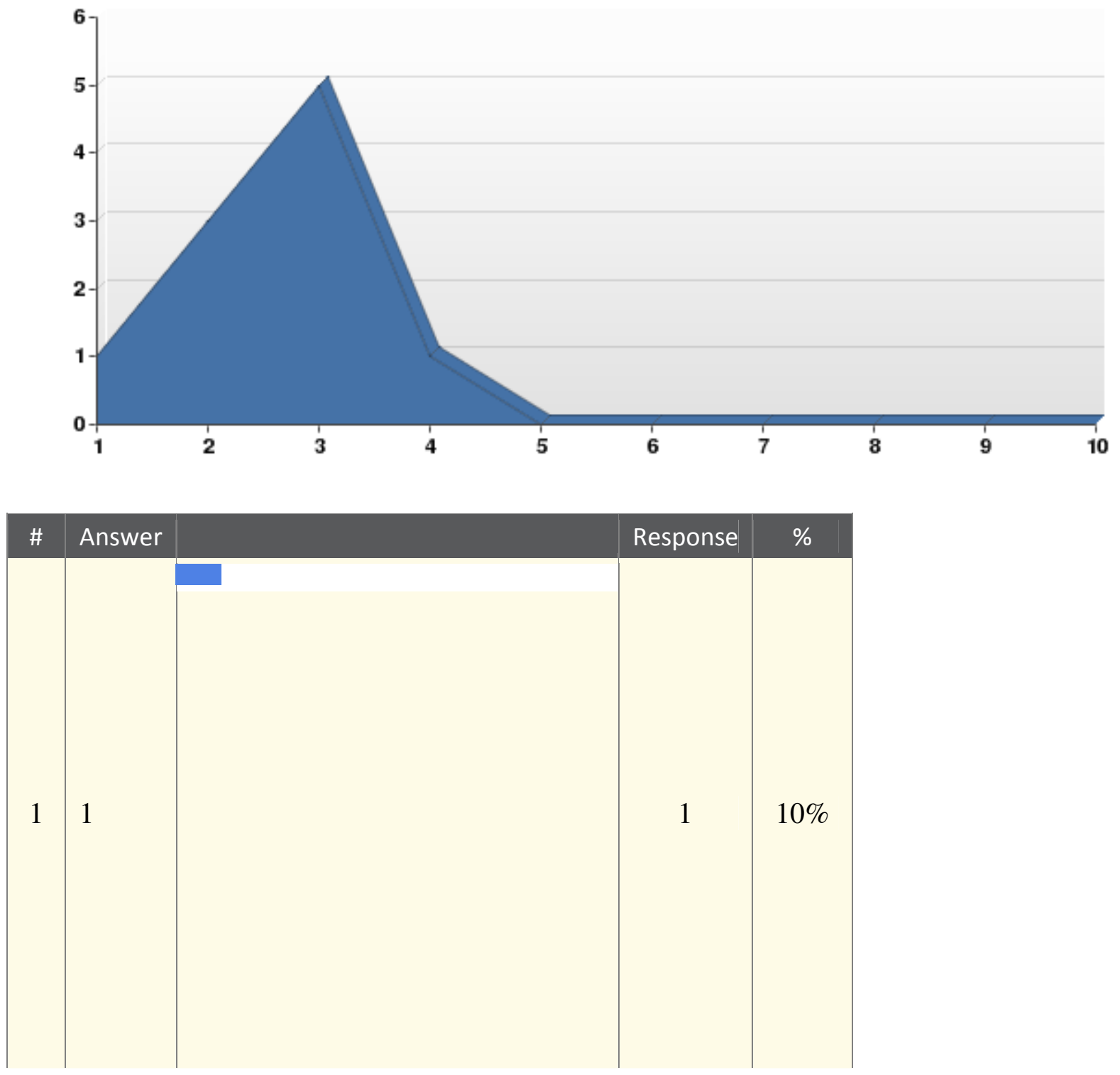

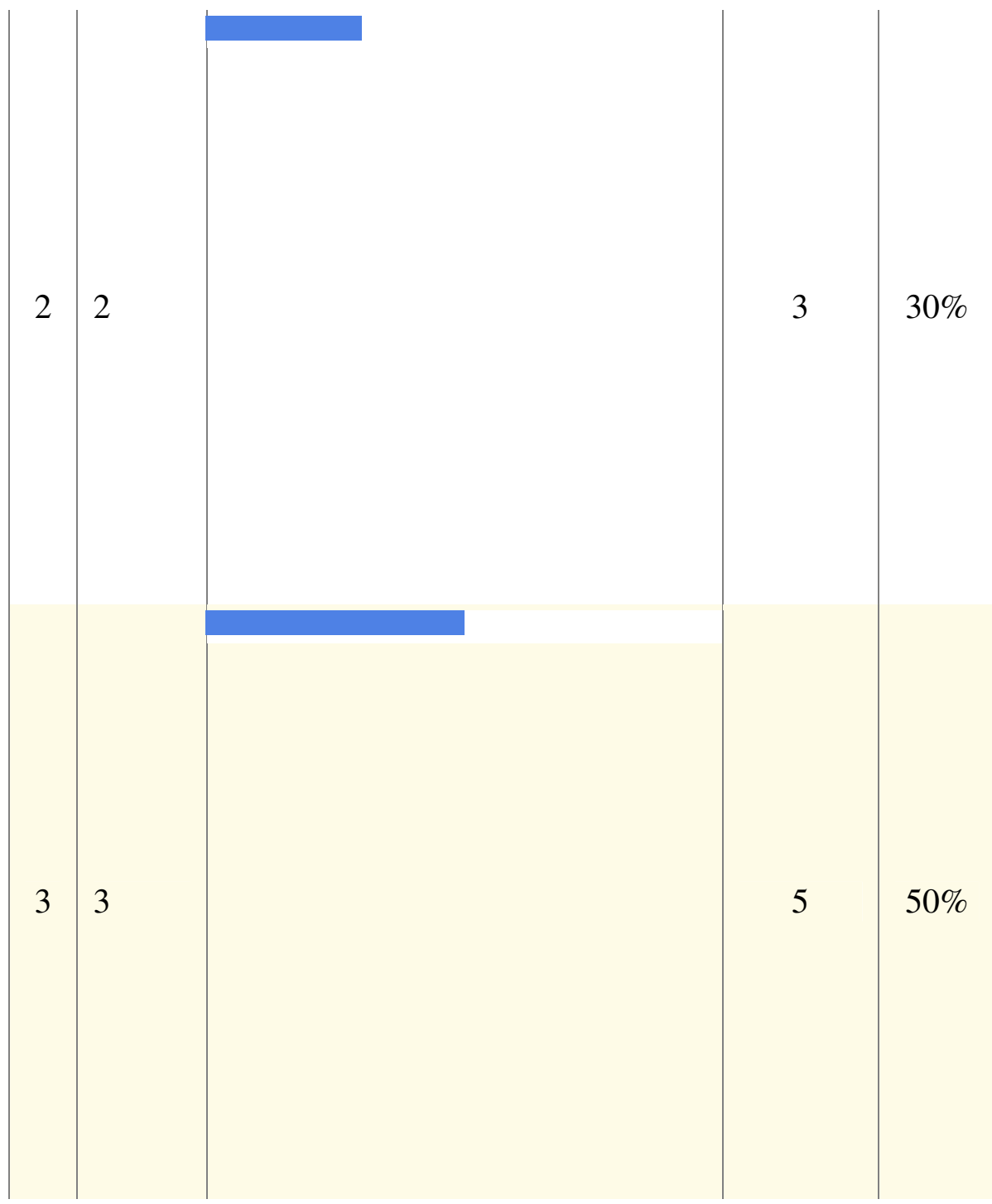

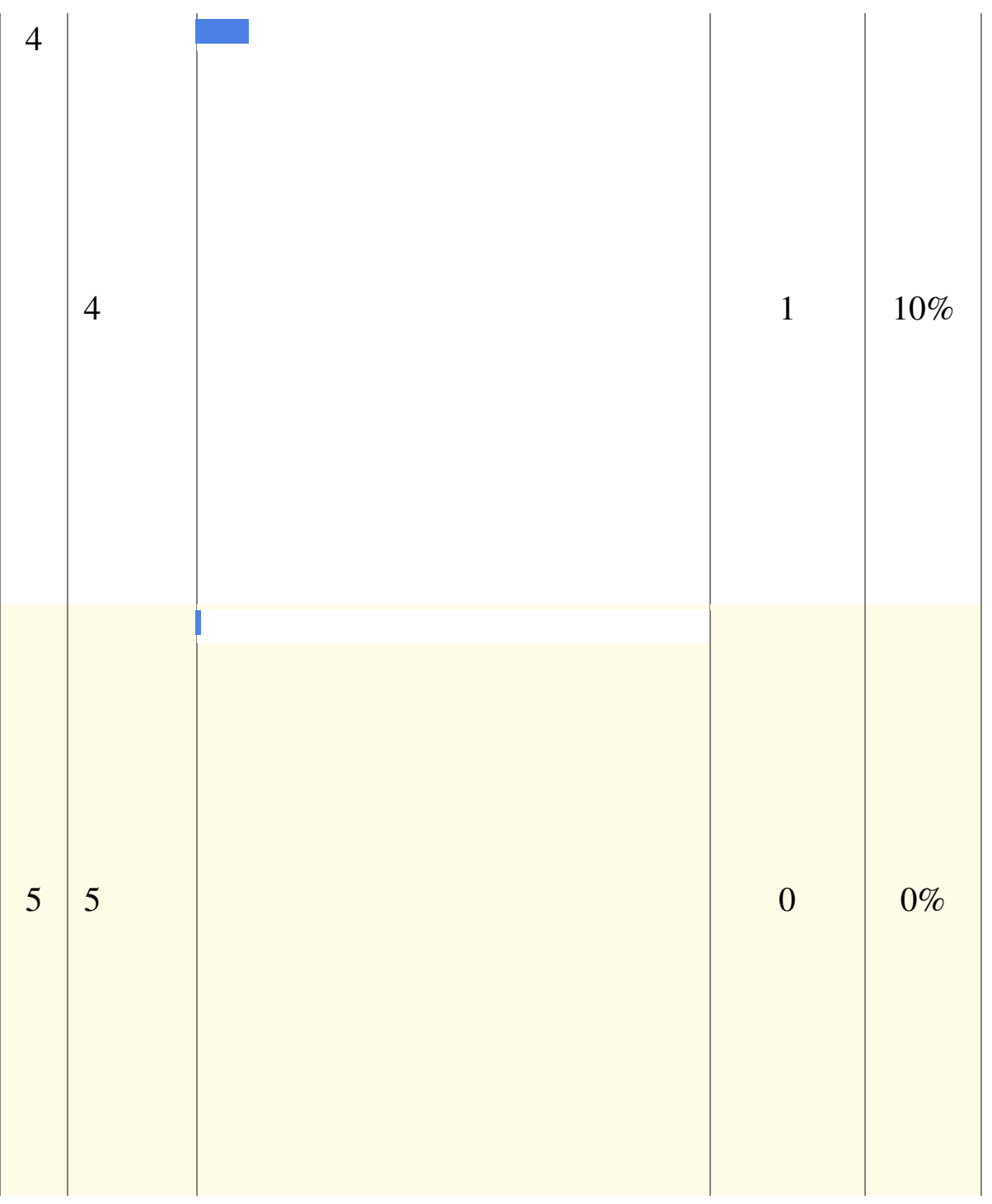

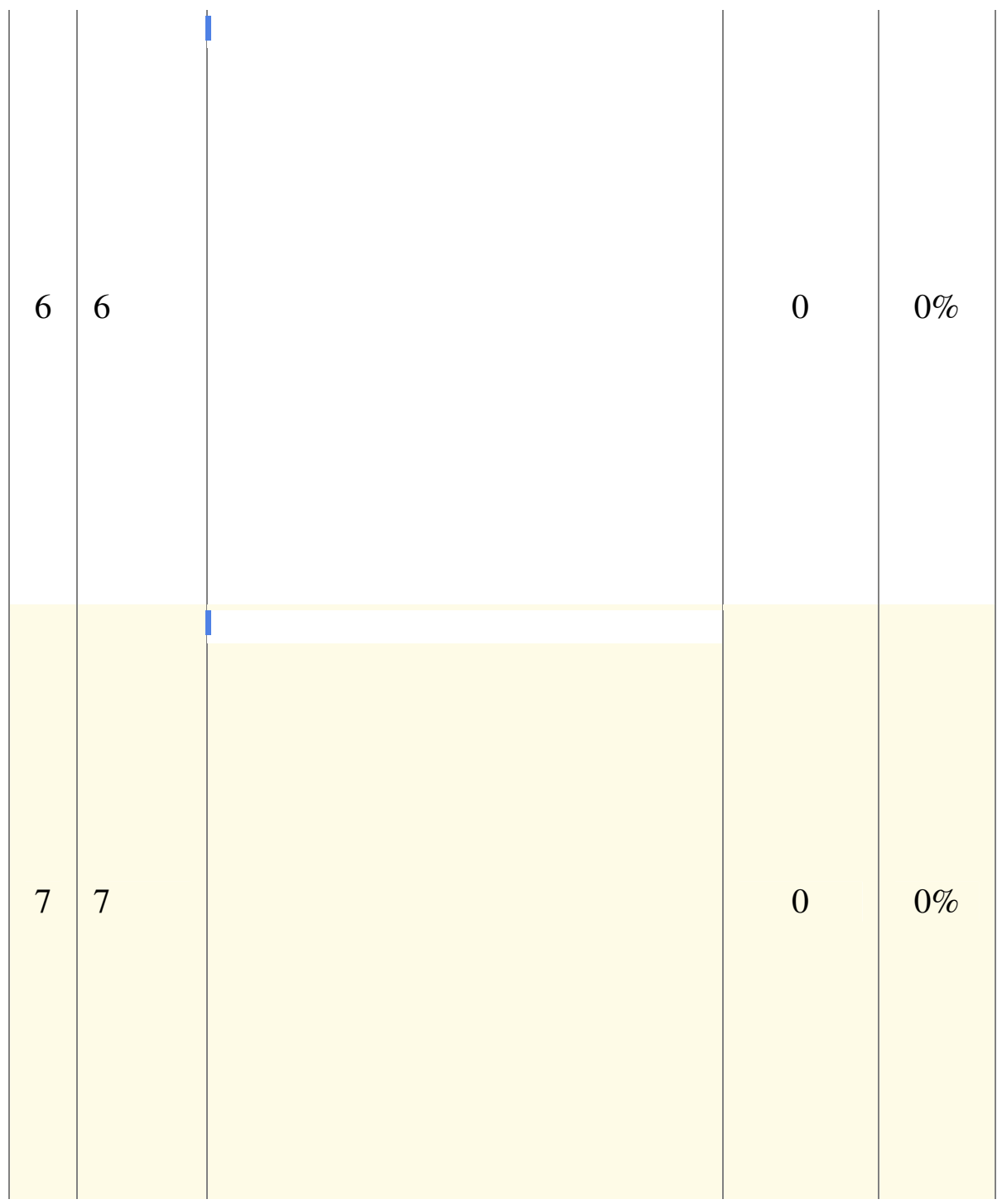

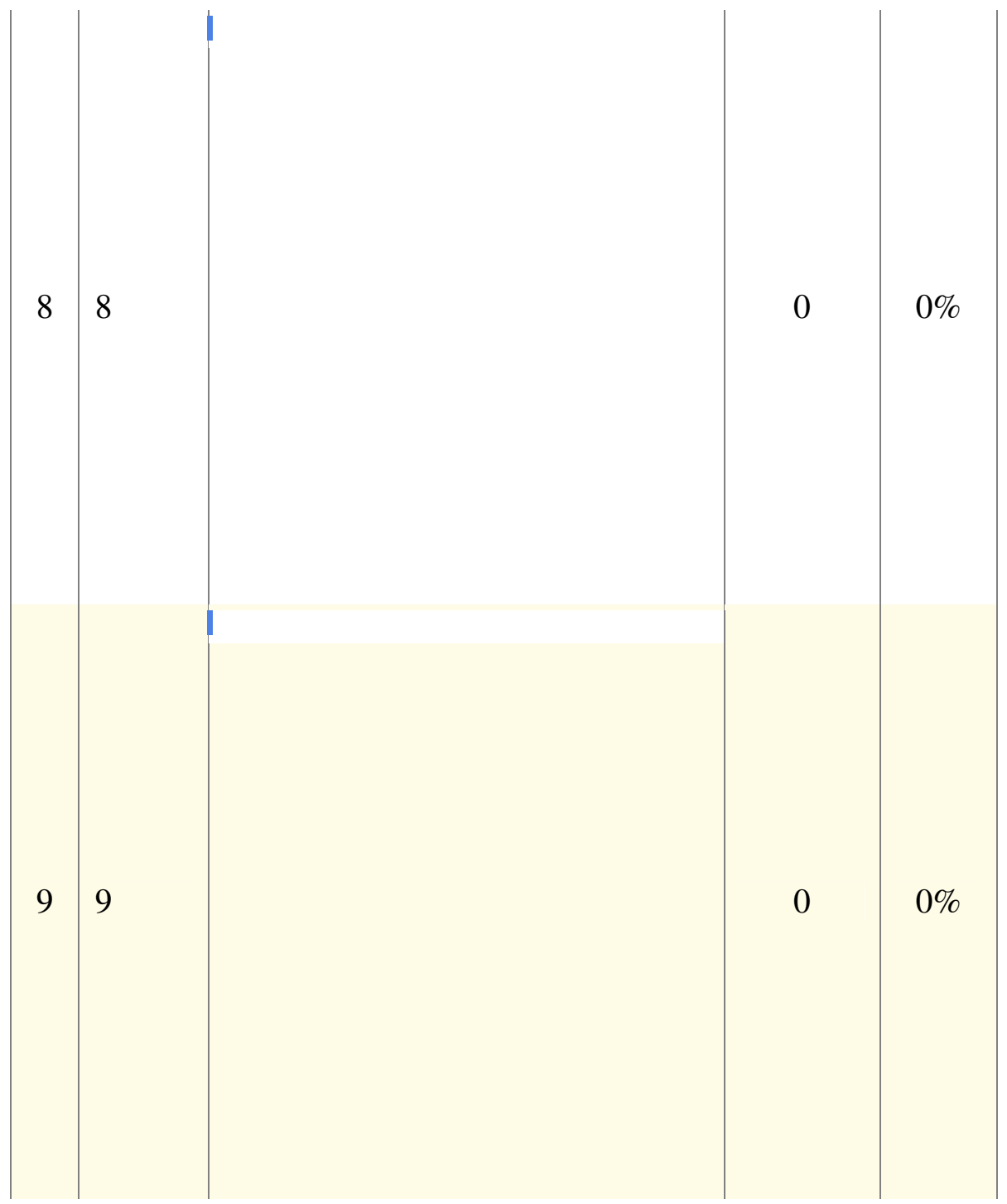


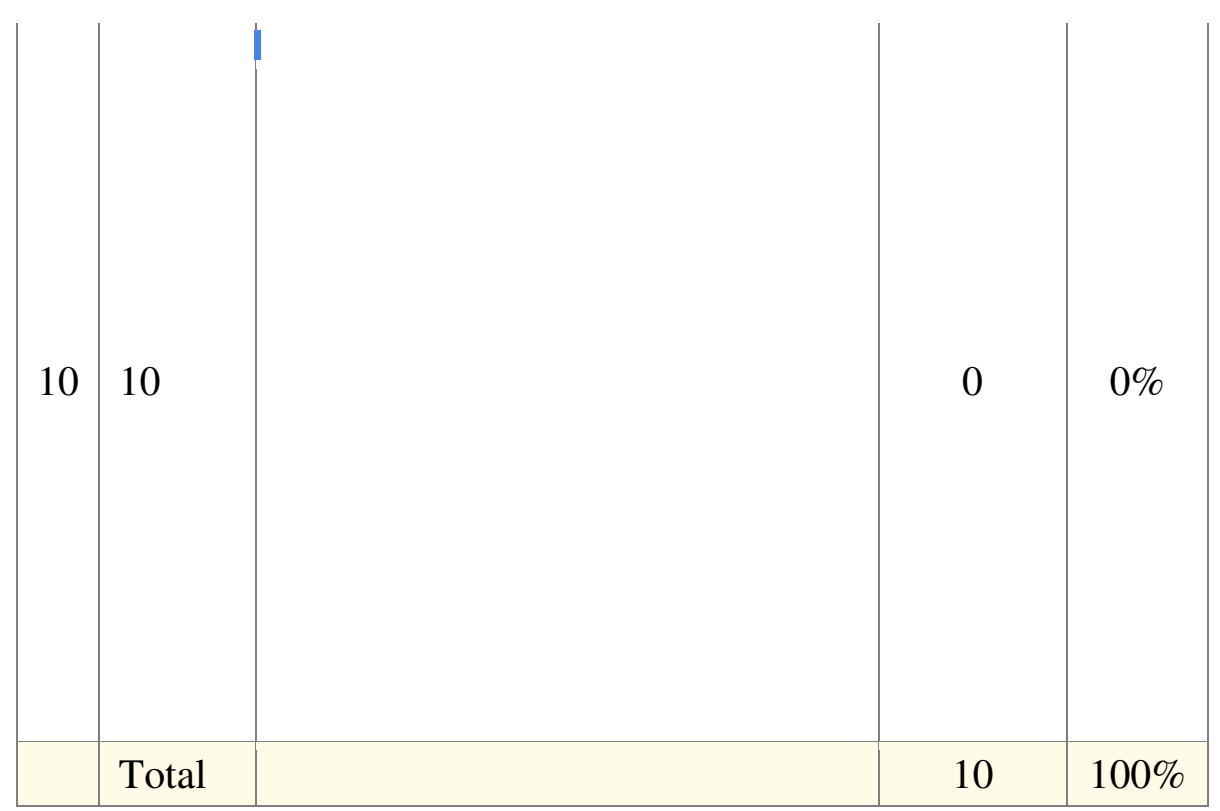

\section{Please rate the following based on the importance of students developing these abilities (203).}

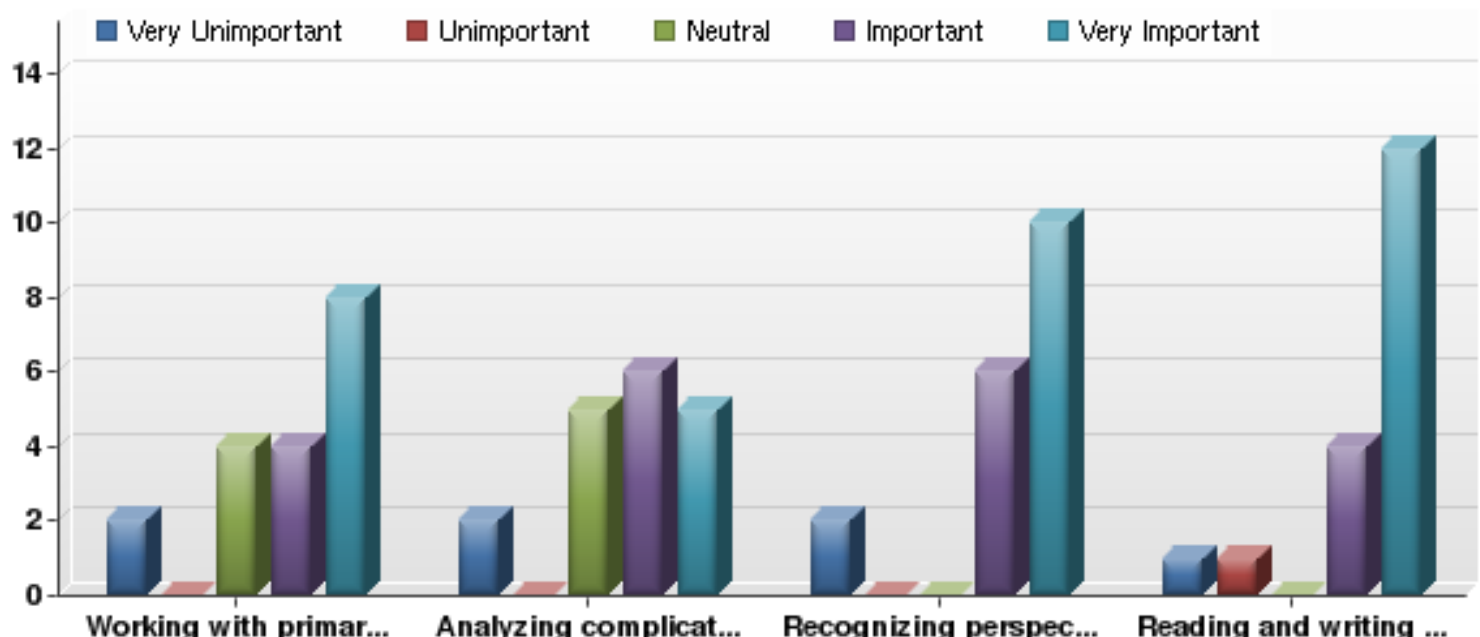

\begin{tabular}{|l|l|c|c|c|c|c|c|c|}
\hline \# & $\begin{array}{c}\text { Very } \\
\text { Unimportan } \\
\mathrm{t}\end{array}$ & $\begin{array}{c}\text { Unimportan } \\
\mathrm{t}\end{array}$ & $\begin{array}{c}\text { Neutra } \\
\mathrm{I}\end{array}$ & $\begin{array}{c}\text { Importan } \\
\mathrm{t}\end{array}$ & $\begin{array}{c}\text { Very } \\
\text { Importan } \\
\mathrm{t}\end{array}$ & $\begin{array}{c}\text { Response } \\
\mathrm{s}\end{array}$ & Mean \\
\hline 1 & $\begin{array}{l}\text { Working } \\
\text { with } \\
\text { primary }\end{array}$ & 2 & 0 & 4 & 4 & 8 & 18 & 3.89 \\
\hline
\end{tabular}




\begin{tabular}{|c|c|c|c|c|c|c|c|c|}
\hline & $\begin{array}{l}\text { sources } \\
\text { competently }\end{array}$ & & & & & & & \\
\hline 2 & $\begin{array}{l}\text { Analyzing } \\
\text { complicated } \\
\text { pieces of } \\
\text { data in } \\
\text { order to } \\
\text { extrapolate } \\
\text { history }\end{array}$ & 2 & 0 & 5 & 6 & 5 & 18 & 3.67 \\
\hline 3 & $\begin{array}{l}\text { Recognizin } \\
\mathrm{g} \\
\text { perspective } \\
\text { and bias in } \\
\text { both } \\
\text { primary ans } \\
\text { secondary } \\
\text { sources }\end{array}$ & 2 & 0 & 0 & 6 & 10 & 18 & 4.22 \\
\hline 4 & $\begin{array}{l}\text { Reading } \\
\text { and writing } \\
\text { skills }\end{array}$ & 1 & 1 & 0 & 4 & 12 & 18 & 4.39 \\
\hline
\end{tabular}

\begin{tabular}{|l|c|c|c|c|}
\hline Statistic & $\begin{array}{c}\text { Working with } \\
\text { primary sources } \\
\text { competently }\end{array}$ & $\begin{array}{c}\text { Analyzing complicated } \\
\text { pieces of data in order } \\
\text { to extrapolate history }\end{array}$ & $\begin{array}{c}\text { Recognizing perspective } \\
\text { and bias in both primary } \\
\text { ans secondary sources }\end{array}$ & $\begin{array}{c}\text { Reading } \\
\text { and writing } \\
\text { skills }\end{array}$ \\
\hline Mean & 3.89 & 3.67 & 4.22 & 4.39 \\
Variance & 1.75 & 1.53 & 1.59 & 1.31 \\
Standard & 1.32 & 1.24 & 1.26 & 1.14 \\
Deviation & 18 & 18 & 18 & 18 \\
Total & & & & 18 \\
Responses & 18 & & & \\
\hline
\end{tabular}

\section{Does your history department have a defined set of outcome objectives for undergraduate history majors (204)?}



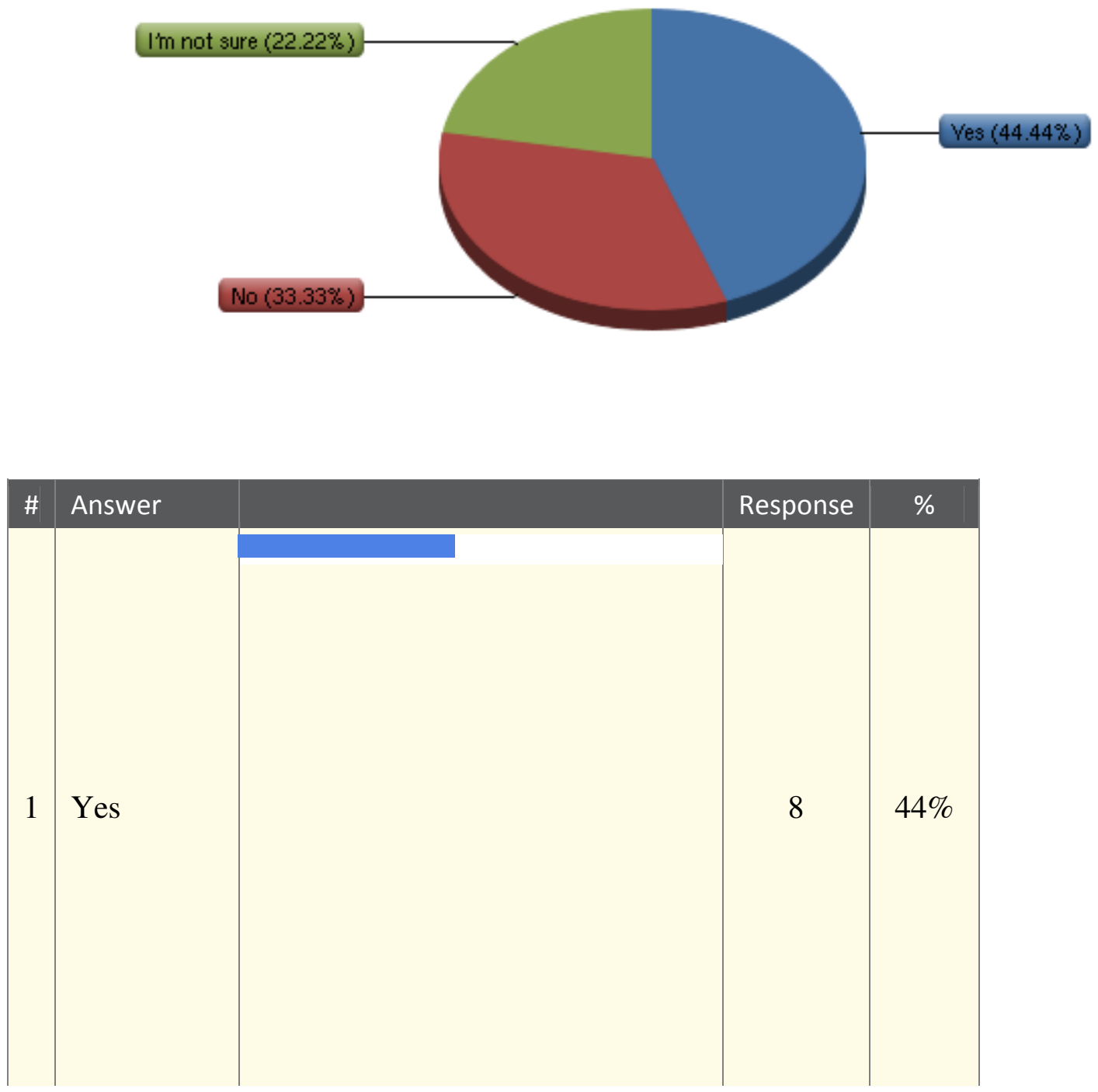


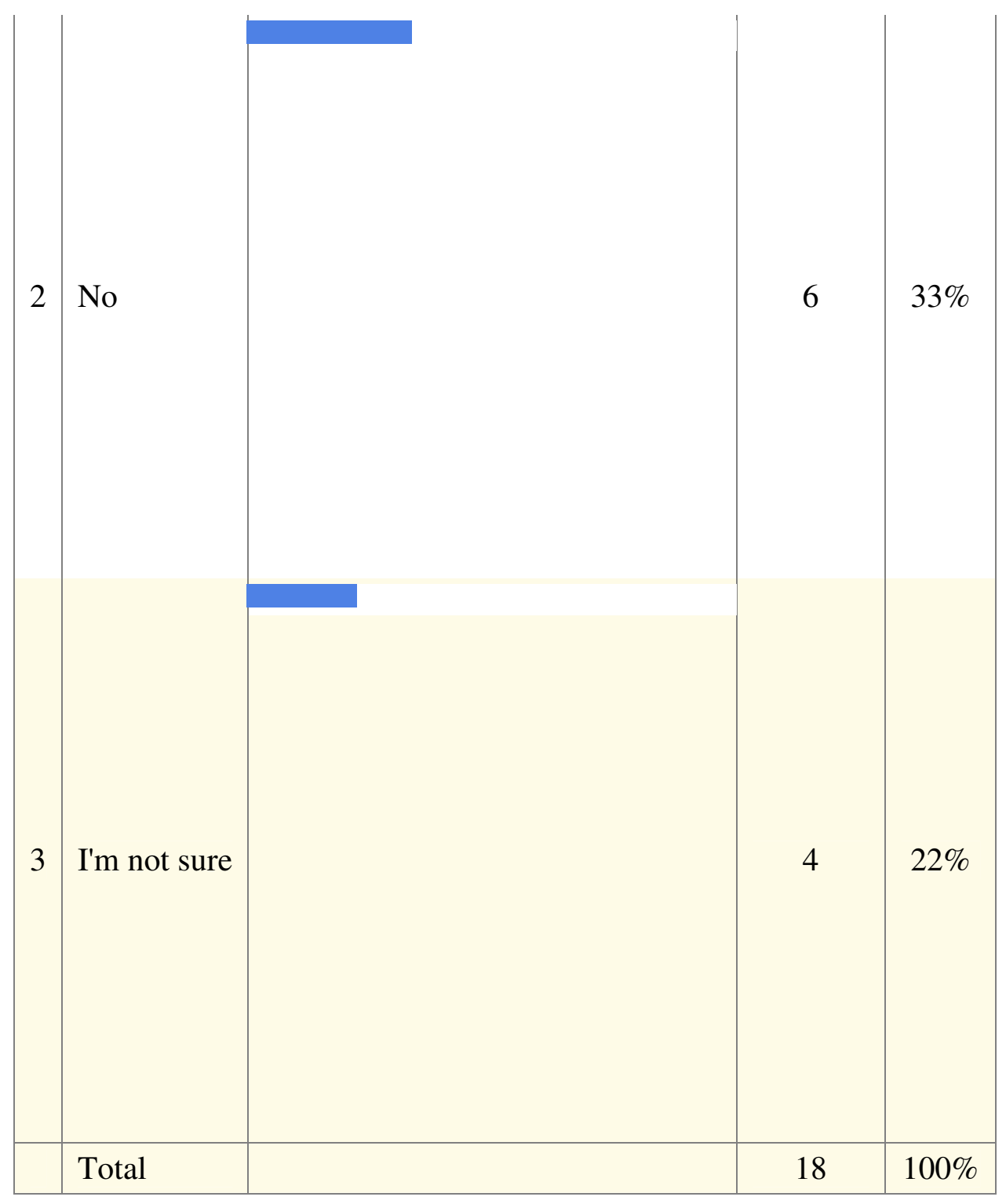

7. Which of the following options do you feel closely relates to the objectives defined by your history department: (Check all that apply) (page 205). 

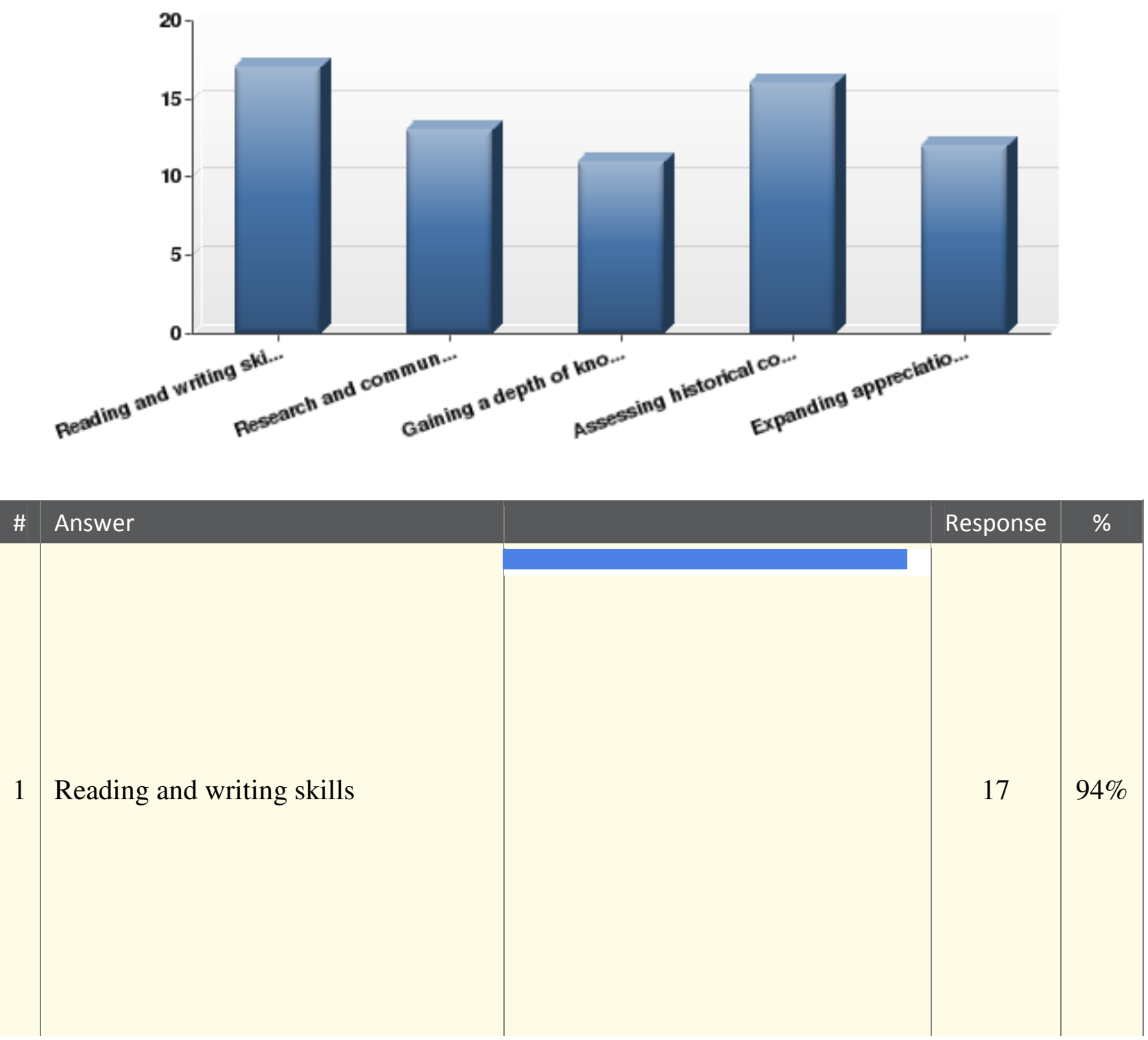
2 Research and communication skills

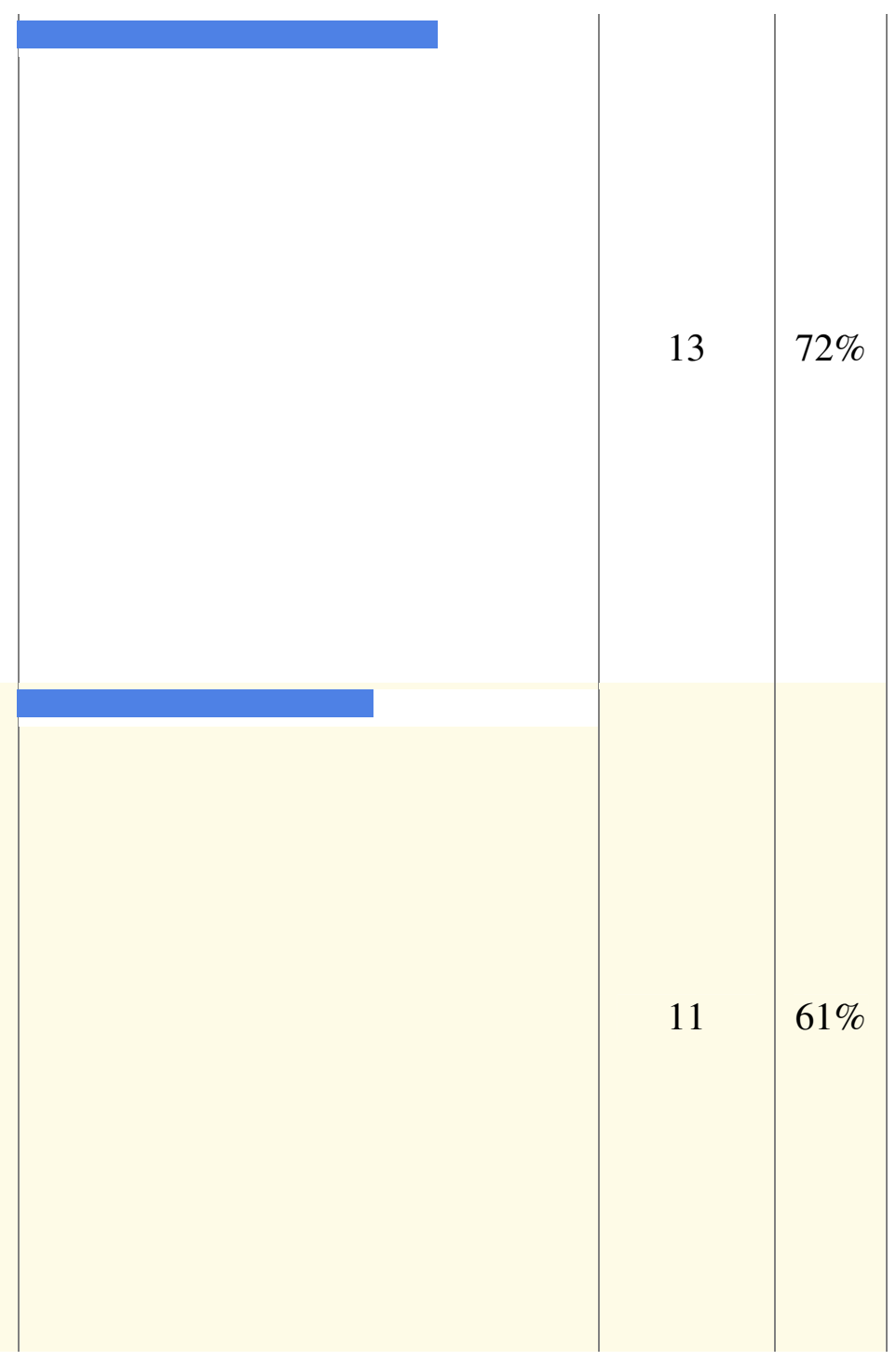

3 Gaining a depth of knowledge of a particular time-period 
Assessing historical context and

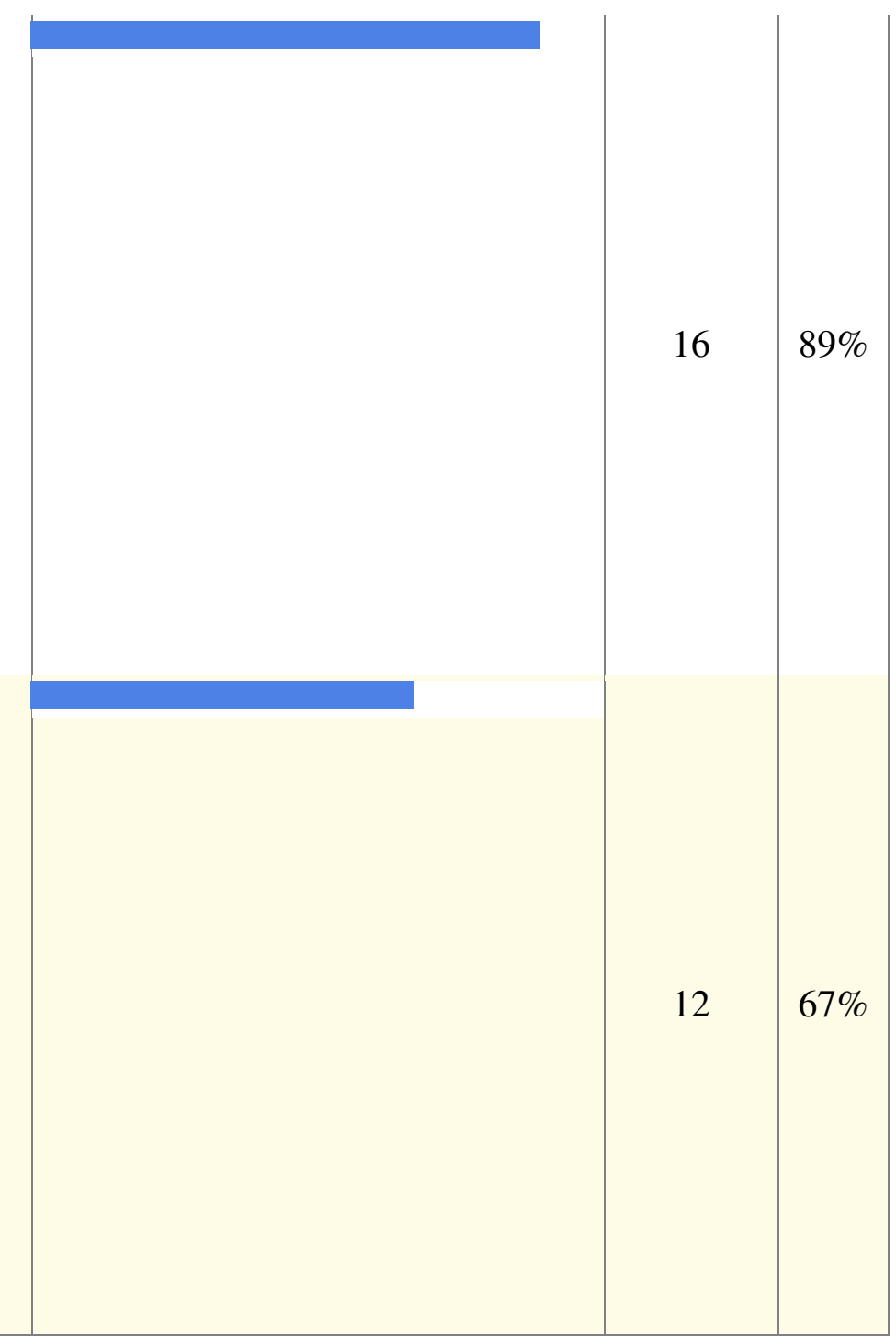

5 Expanding appreciation and understanding for past cultures

\section{The teachers in my history department have a parallel focus and} are working to establish the same goals (206). 

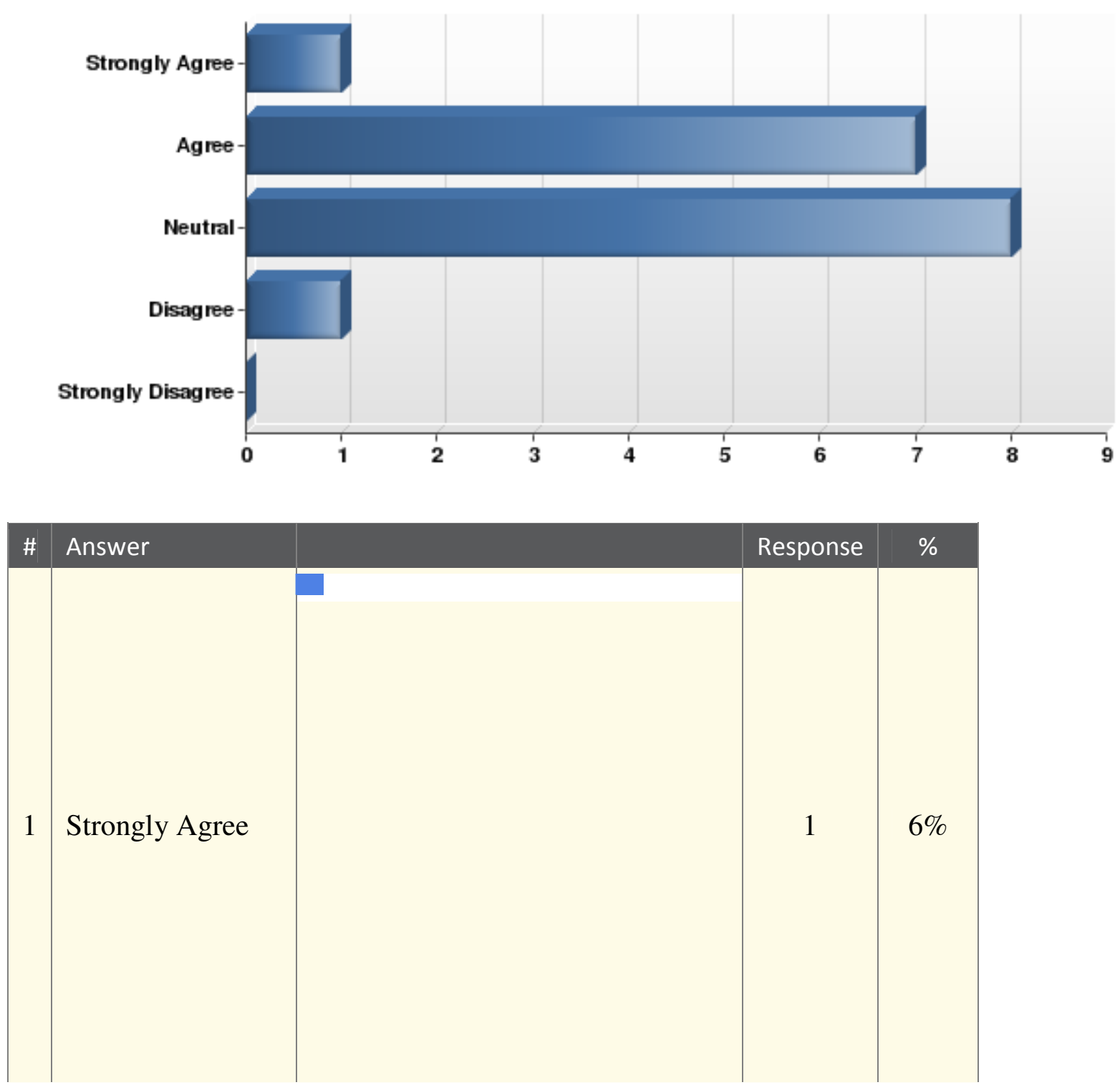


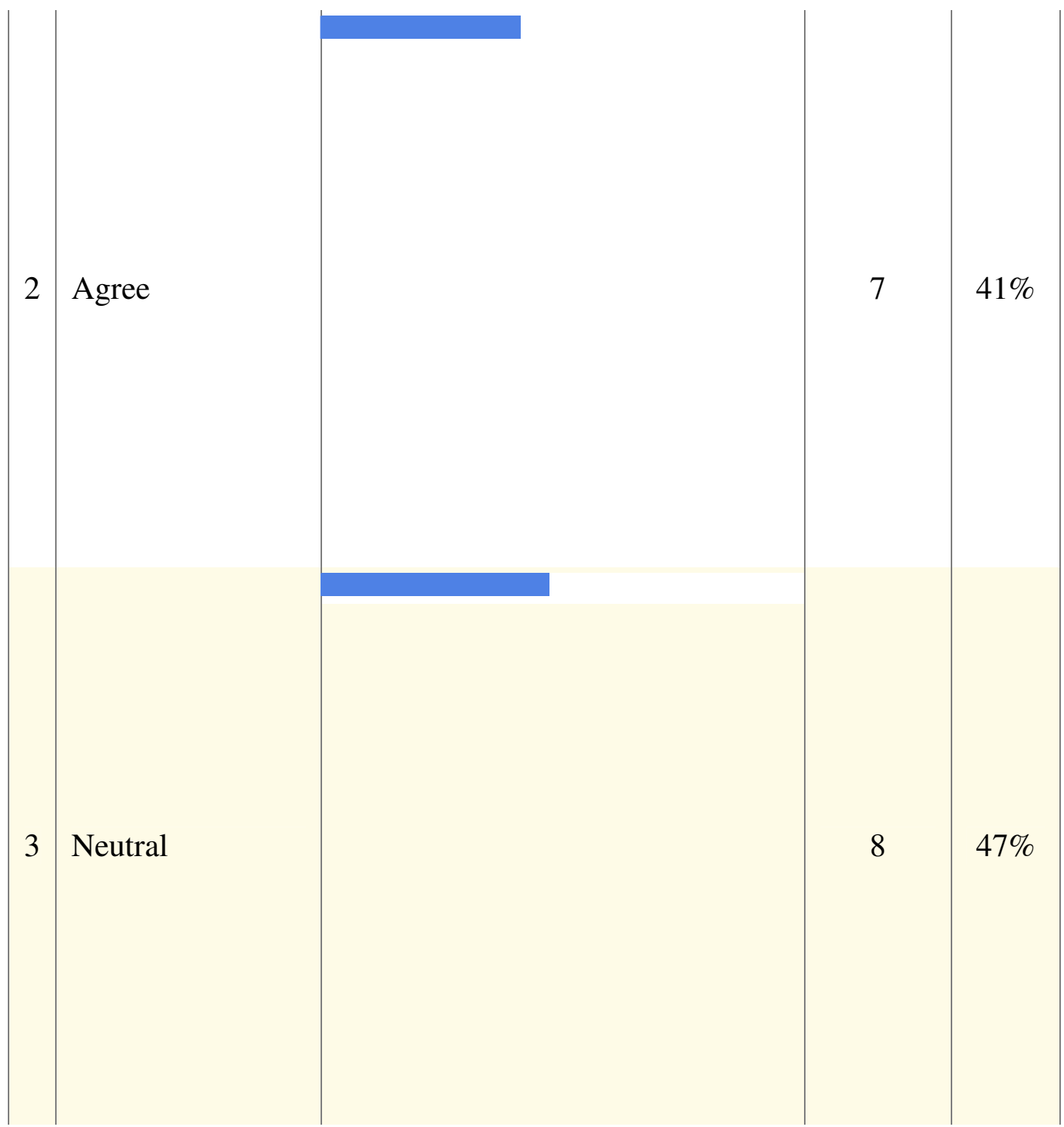




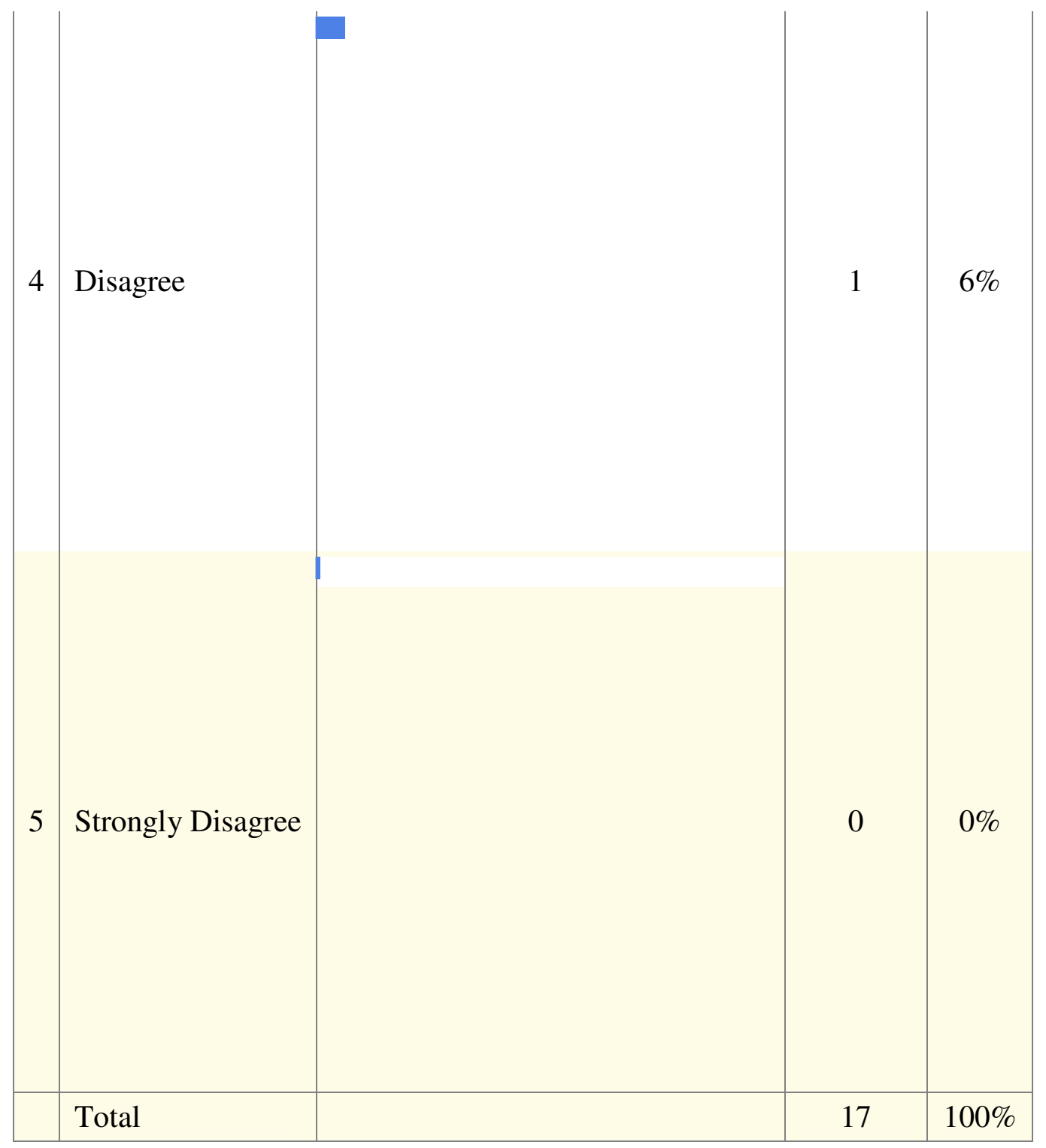

\section{If you could add an outcome objective for your history students,} what would it be (207)?

\section{Text Response}

An appreciation for the importance of historical study.

N/A

Genuinely critical thinking

Better writing and analytic skills. 
Creating an argument supported by appropriate evidence.

To refine skills of reading, writing, and analysis. To understand the past in its own terms, particularly those options open to decision makers in the world in which they lived To understand the foundations, history, and institutions of the United States in order to become responsible, infomed citizens. The current emphasis of race, ethnicity, and gender means that students have mastered the margins of history at the expense of the core. It means that their historical knowledge is frequently a mile wide and an inch deep. One cannot ne an iconoclast without knowledge of the icons.

\section{If you could delete an outcome objective for your Egyptian history students, what would it be?}

\section{Text Response}

N/A

In-depth knowledge of particular dates and time periods

An awareness of the past and its relationship to the present. Above all, to recognize that studying history means uncovering untruth.

\section{Please list in order of importance what the two main objectives should be for a history class (208).}

\section{Text Response}

1) To teach students to think critically. 2) To teach students to write clearly.

Ability to analyse documents Appreciation of cultural specificity teach the subject cultivate critical analytical skills and writing

1. Learning about the subject matter of the course, whatever that is. 2. Developing a set of conceptual tools for understanding and explaining change over time, especially with regard to the course's subject.

Developing students' ability to think historically through the study of a particular time, place, and/or topic. This entails the development of skills in critical analysis of documents and of historical actors' perspectives, motivations, and actions. The development of skills related to effective communication: reading with comprehension; listening with care; writing clearly and effectively; and participating in open-ended and productive discussions.

Learn about the past Analyze the material in a balanced, objective way

Think clearly and critically about the past

1. Understanding that the world has not always been the way the students have experienced it.

2. Practice at careful reading and writing. 
Love of reading appreciate Historical distance

Raising broader questions as context for historical information Helping students to recognize the context in which decisions were made, and read documents critically.

Attendance Reading assigned materials.

Introduce students to human experience in the past Help them learn to analyze historical data fairly and insightfully

1. development of critical thinking and reading skills 2 . development of writing skills

1. Reading and writing skills 2 . Understanding the past in its own context but also how it informs the present

\section{Please respond to the following statements as to their importance to teaching history (209):}

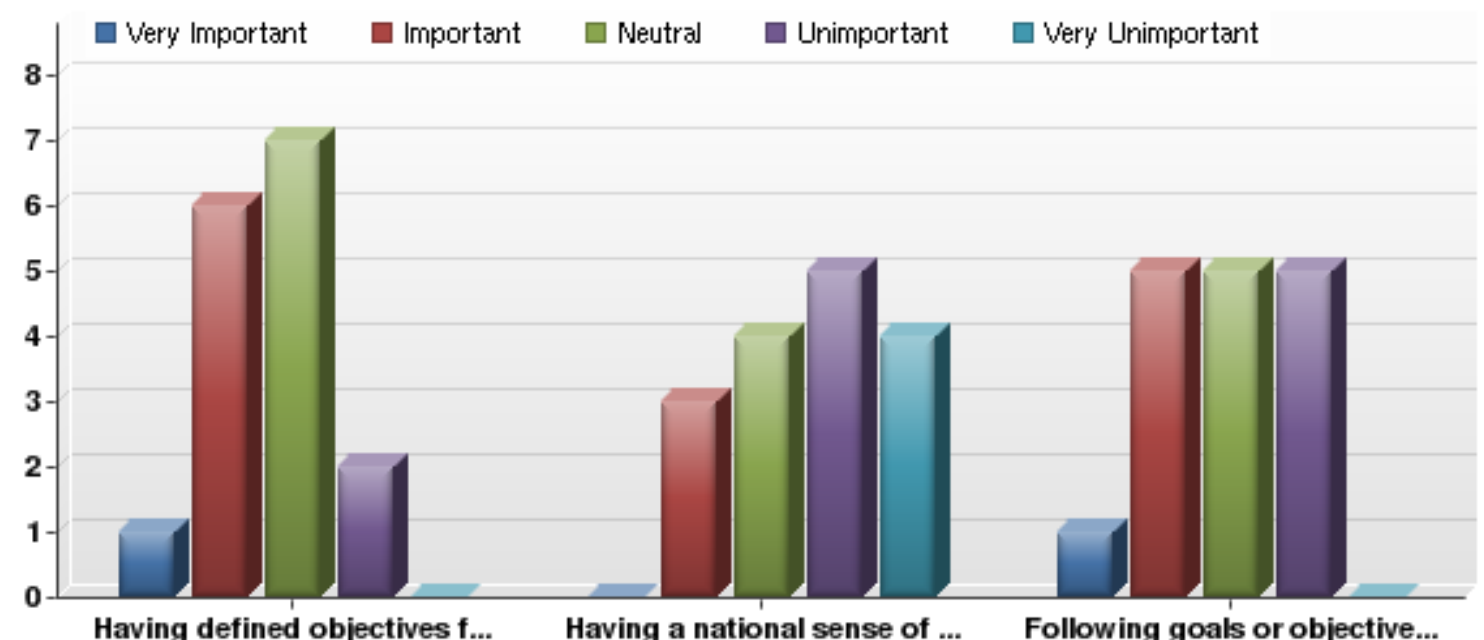

\begin{tabular}{|l|l|c|c|c|c|c|c|c|}
\hline \# & Question & $\begin{array}{c}\text { Very } \\
\text { Importan } \\
\mathrm{t}\end{array}$ & $\begin{array}{c}\text { Importan } \\
\mathrm{t}\end{array}$ & $\begin{array}{c}\text { Neutra } \\
\mathrm{I}\end{array}$ & $\begin{array}{c}\text { Unimportan } \\
\mathrm{t}\end{array}$ & $\begin{array}{c}\text { Very } \\
\text { Unimportan } \\
\mathrm{t}\end{array}$ & $\begin{array}{c}\text { Response } \\
\mathrm{s}\end{array}$ & Mean \\
\hline & $\begin{array}{l}\text { Having } \\
\text { defined } \\
\text { objectives } \\
\text { for the } \\
\text { department } \\
\text { to follow }\end{array}$ & 1 & 6 & 7 & 2 & 0 & 16 & 2.63 \\
\hline & $\begin{array}{l}\text { Having a } \\
\text { national }\end{array}$ & 0 & 3 & 4 & 5 & 4 & 16 & 3.63
\end{tabular}




\begin{tabular}{|c|c|c|c|c|c|c|c|c|}
\hline & $\begin{array}{l}\text { sense of } \\
\text { how history } \\
\text { department } \\
\text { s should } \\
\text { teach }\end{array}$ & & & & & & & \\
\hline 3 & $\begin{array}{l}\text { Following } \\
\text { goals or } \\
\text { objectives } \\
\text { outlined by } \\
\text { the } \\
\text { department }\end{array}$ & 1 & 5 & 5 & 5 & 0 & 16 & 2.88 \\
\hline
\end{tabular}

\begin{tabular}{|l|c|c|c|}
\hline Statistic & $\begin{array}{c}\text { Having defined objectives } \\
\text { for the department to } \\
\text { follow }\end{array}$ & $\begin{array}{c}\text { Having a national sense of } \\
\text { how history departments } \\
\text { should teach }\end{array}$ & $\begin{array}{c}\text { Following goals or } \\
\text { objectives outlined by the } \\
\text { department }\end{array}$ \\
\hline Mean & 2.63 & 3.63 & 2.88 \\
Variance & 0.65 & 1.18 & 0.92 \\
Standard & 0.81 & 1.09 & 0.96 \\
$\begin{array}{l}\text { Deviation } \\
\text { Total }\end{array}$ & 16 & 16 & 16 \\
Responses & 16 & & \\
\hline
\end{tabular}

\section{Please respond to the following statements based on your teaching experience (page 210):}

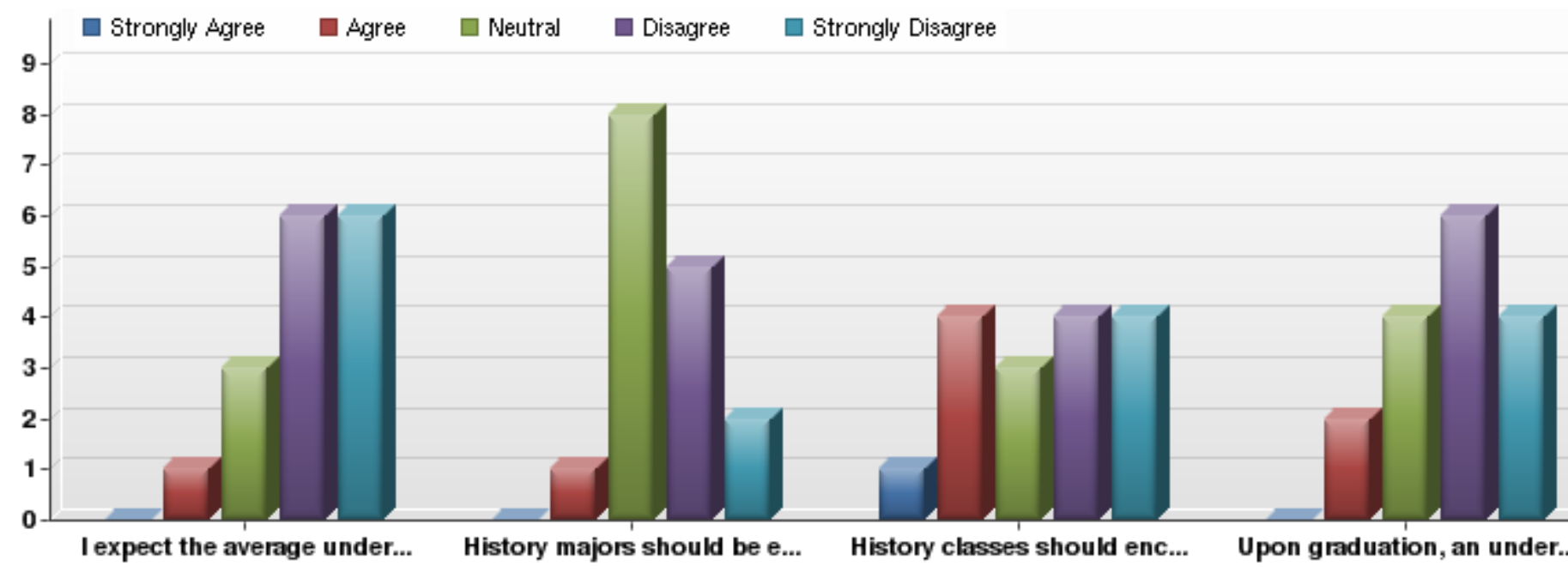




\begin{tabular}{|c|c|c|c|c|c|c|c|c|}
\hline \# & Question & $\begin{array}{l}\text { Strongly } \\
\text { Agree }\end{array}$ & Agree & Neutral & Disagree & $\begin{array}{l}\text { Strongly } \\
\text { Disagree }\end{array}$ & Responses & Mean \\
\hline 1 & $\begin{array}{l}\text { I expect the average } \\
\text { undergraduate history } \\
\text { major to attend } \\
\text { graduate school }\end{array}$ & 0 & 1 & 3 & 6 & 6 & 16 & 4.06 \\
\hline 2 & $\begin{array}{l}\text { History majors should } \\
\text { be encouraged to attend } \\
\text { graduate school }\end{array}$ & 0 & 1 & 8 & 5 & 2 & 16 & 3.50 \\
\hline 3 & $\begin{array}{l}\text { History classes should } \\
\text { encourage students to } \\
\text { become practicing } \\
\text { historians }\end{array}$ & 1 & 4 & 3 & 4 & 4 & 16 & 3.38 \\
\hline 4 & $\begin{array}{l}\text { Upon graduation, an } \\
\text { undergraduate student } \\
\text { of history would have } \\
\text { adequate training to } \\
\text { work as a historian }\end{array}$ & 0 & 2 & 4 & 6 & 4 & 16 & 3.75 \\
\hline
\end{tabular}

\begin{tabular}{|l|c|c|c|c|}
\hline & $\begin{array}{c}\text { I expect the average } \\
\text { undergraduate } \\
\text { history major to } \\
\text { attend graduate } \\
\text { school }\end{array}$ & $\begin{array}{c}\text { History majors } \\
\text { should be } \\
\text { encouraged to } \\
\text { attend graduate } \\
\text { school }\end{array}$ & $\begin{array}{c}\text { History classes } \\
\text { should } \\
\text { encourage } \\
\text { students to } \\
\text { become } \\
\text { practicing } \\
\text { historians }\end{array}$ & $\begin{array}{c}\text { Upon graduation, an } \\
\text { undergraduate student } \\
\text { of history would have } \\
\text { adequate training to } \\
\text { work as a historian }\end{array}$ \\
\hline $\begin{array}{l}\text { Mean } \\
\text { Variance }\end{array}$ & 4.06 & 3.50 & 3.38 & 3.75 \\
$\begin{array}{l}\text { Standard } \\
\text { Deviation }\end{array}$ & 0.86 & 0.67 & 1.72 & 1.00 \\
Total & 0.93 & 0.82 & 1.31 & 1.00 \\
Responses & 16 & 16 & 16 & 16 \\
\hline
\end{tabular}

\section{Which of the following best describes the geographical location of your institution (211)?}



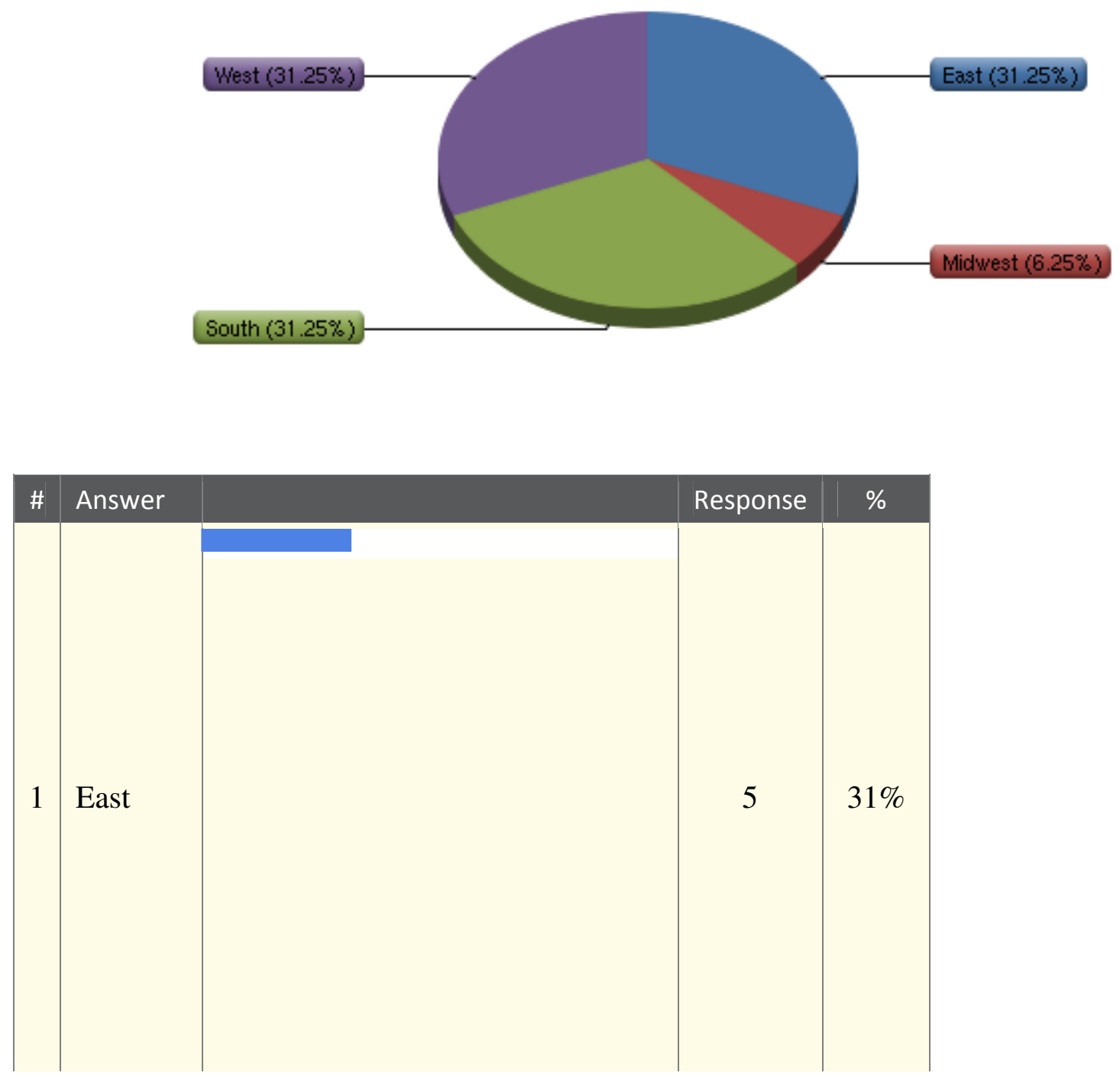

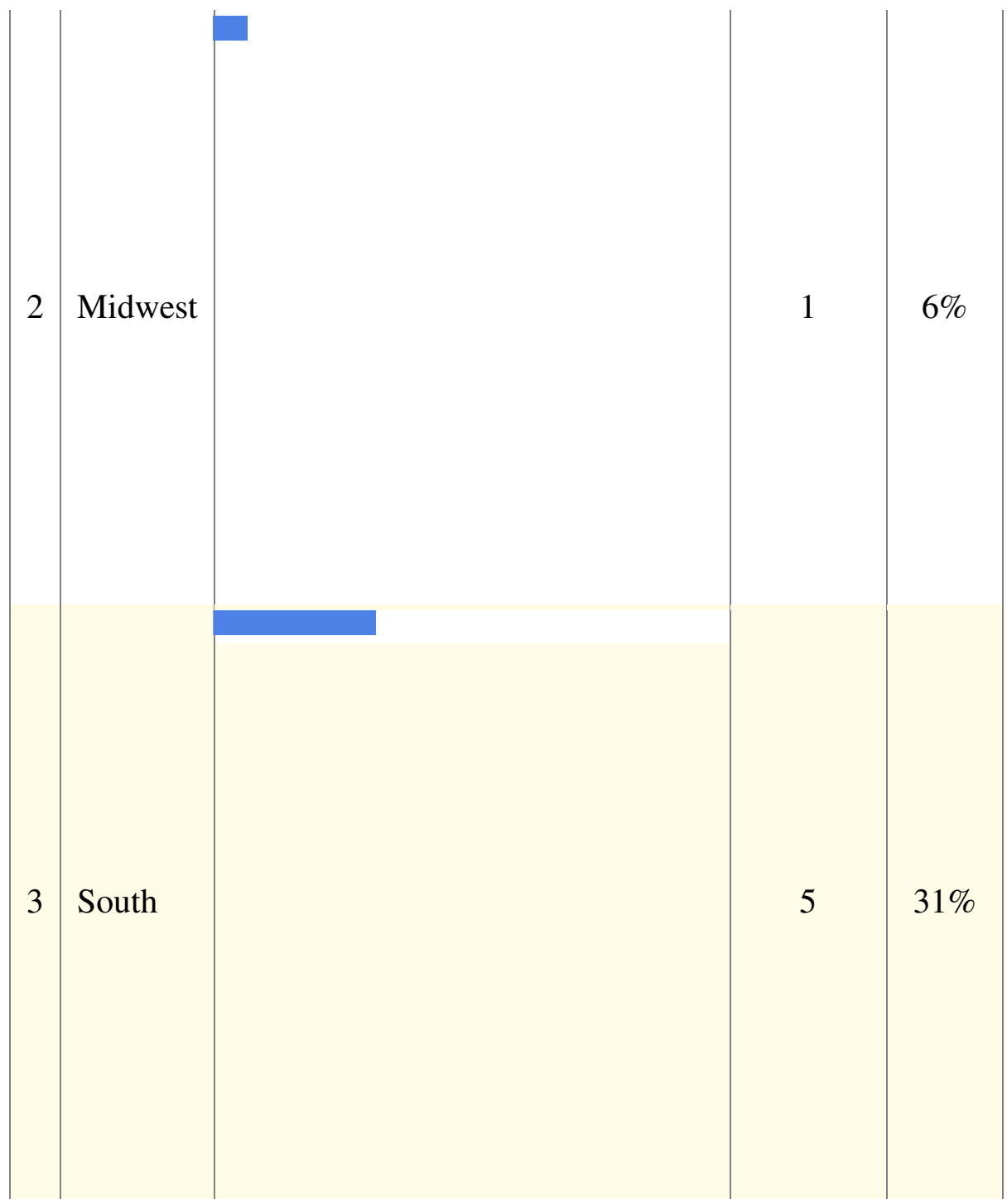


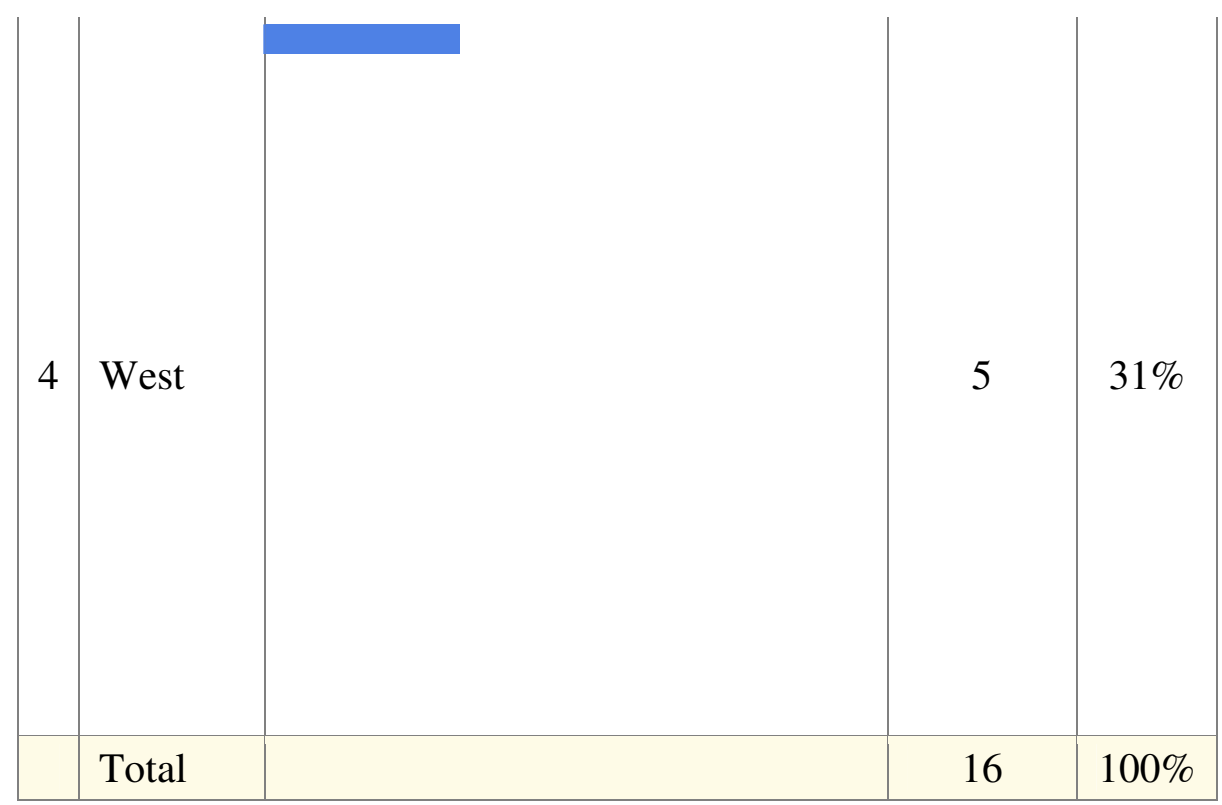

Results of Survey Administered to Egyptologists (212).

\section{Upon completing an undergraduate degree, your department} should have adequately educated students to do the following:

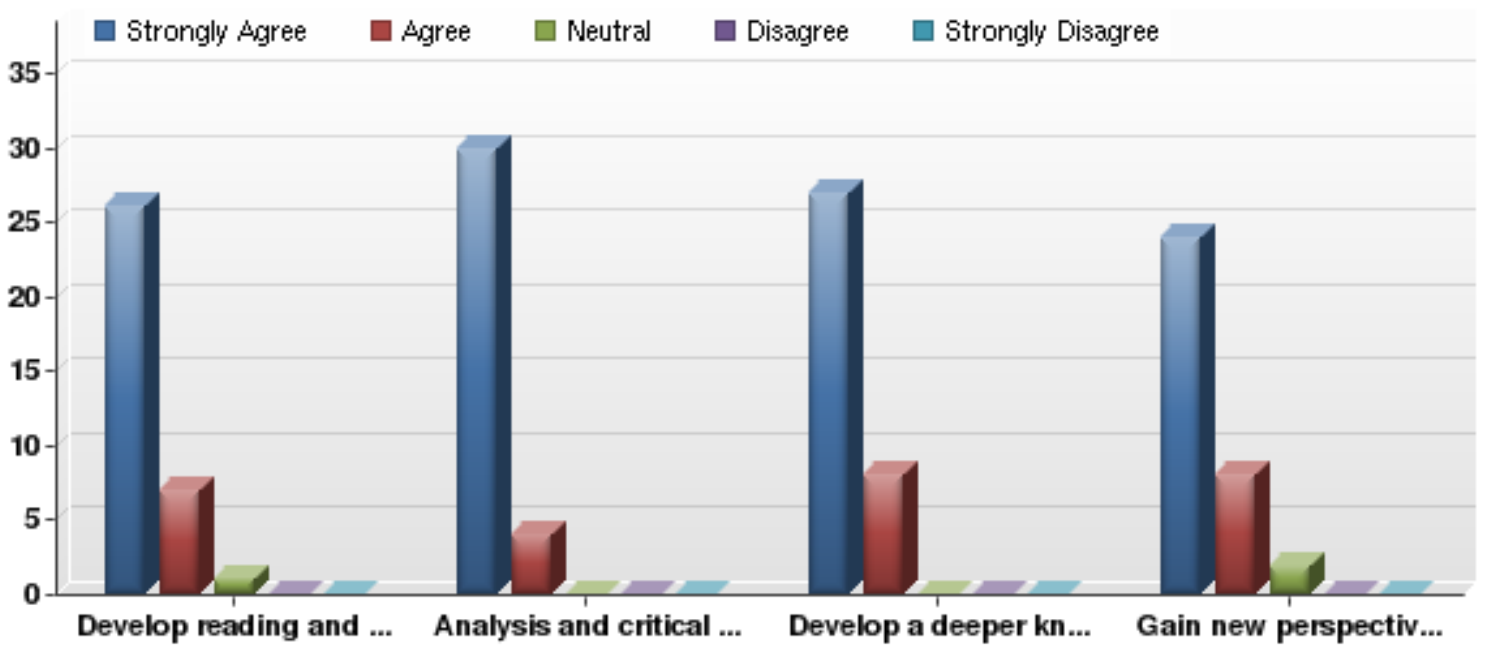




\begin{tabular}{|c|c|c|c|c|c|c|c|}
\hline$\#$ & Question & $\begin{array}{l}\text { Strongly } \\
\text { Agree }\end{array}$ & Agree & Neutral & Disagree & $\begin{array}{l}\text { Strongly } \\
\text { Disagree }\end{array}$ & Responses \\
\hline 1 & $\begin{array}{l}\text { Develop reading and writing } \\
\text { skills. }\end{array}$ & 26 & 7 & 1 & 0 & 0 & 34 \\
\hline 2 & $\begin{array}{l}\text { Analysis and critical } \\
\text { thinking, and the ability to } \\
\text { assess conflicting } \\
\text { interpretations. }\end{array}$ & 30 & 4 & 0 & 0 & 0 & 34 \\
\hline 3 & $\begin{array}{l}\text { Develop a deeper knowledge } \\
\text { of the history of a particular } \\
\text { time and/or place. }\end{array}$ & 27 & 8 & 0 & 0 & 0 & 35 \\
\hline 4 & $\begin{array}{l}\text { Gain new perspectives by } \\
\text { understanding past cultures. }\end{array}$ & 24 & 8 & 2 & 0 & 0 & 34 \\
\hline
\end{tabular}

\begin{tabular}{|l|c|c|c|c|}
\hline Statistic & $\begin{array}{c}\text { Develop } \\
\text { reading and } \\
\text { writing } \\
\text { skills. }\end{array}$ & $\begin{array}{c}\text { Analysis and critical } \\
\text { thinking, and the ability to } \\
\text { assess conflicting } \\
\text { interpretations. }\end{array}$ & $\begin{array}{c}\text { Develop a deeper } \\
\text { knowledge of the } \\
\text { history of a particular } \\
\text { time and/or place. }\end{array}$ & $\begin{array}{c}\text { Gain new } \\
\text { perspectives by } \\
\text { understanding past } \\
\text { cultures. }\end{array}$ \\
\hline $\begin{array}{l}\text { Total } \\
\text { Responses }\end{array}$ & 34 & 34 & 34 & 34 \\
\hline
\end{tabular}

\section{Please rank the following items from 1-5 in order of importance in your teaching undergraduate students. (1 being the most important, 2 as next important...5 as least important.) (page 213).}




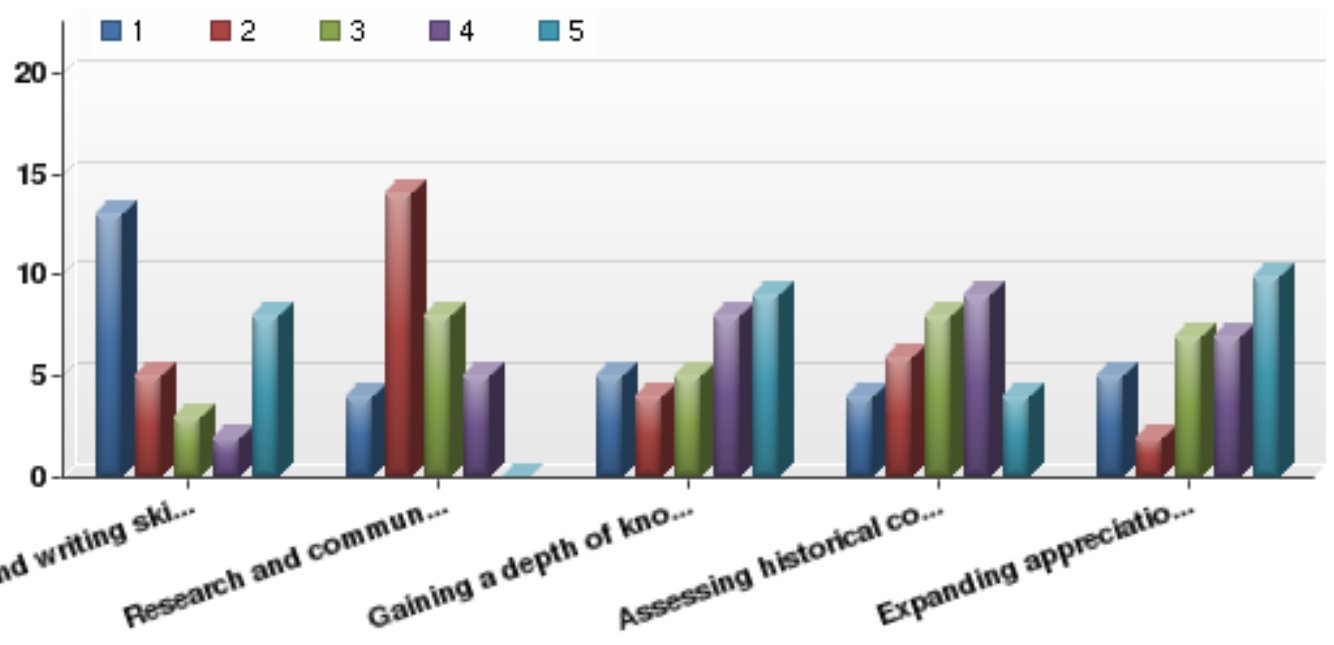

\begin{tabular}{|l|l|r|r|r|r|r|c|}
\hline \# & Answer & 1 & 2 & 3 & 4 & 5 & Responses \\
\hline 1 & Reading and writing skills & 13 & 5 & 3 & 2 & 8 & 31 \\
2 & 4 & 14 & 8 & 5 & 0 & 31 \\
3 & $\begin{array}{l}\text { Research and communication skills } \\
\text { Gaining a depth of knowledge of a particular time- } \\
\text { period }\end{array}$ & 5 & 4 & 5 & 8 & 9 & 31 \\
4 & $\begin{array}{l}\text { Assessing historical context and analyzing historical } \\
\text { documents }\end{array}$ & 4 & 6 & 8 & 9 & 4 & 31 \\
\hline 5 & $\begin{array}{l}\text { Expanding appreciation and understanding for past } \\
\text { cultures. }\end{array}$ & 5 & 2 & 7 & 7 & 10 & 31 \\
\hline & Total & 31 & 31 & 31 & 31 & 31 & \\
\hline
\end{tabular}

\section{In your opinion, is there a skill that should be taught to your undergraduate students, but has been neglected in the required course work (page 214)?}

\section{Text Response}

Paper writing--i.e. the ability to gather information from a variety of sources, analyzie it, the put together the whole into a coherent thesis. Research skills develop out of the ability to do these three things rather than research skills acting as a means towards good paper writing. The ability to write well is the key to many other desired skills that one hopes will come out of a liberal education.

no

$\mathrm{n} / \mathrm{a}$ as I've not been teaching undergraduates 
Critical thinking

Evaluating sources for research

I think that reading, writing, speech, and critical thinking should be taught, but NOT by me. I am an Egyptologist. Those skills should be taught be specialists in those areas. Our institution does not teach any of them. I do the best I can, but this is not my area of expertise.

Learning foreign languages and using them as a research tool

I think one of the most important things we should be doing at the undergraduate is to encourage and train students to think critically (using the lure of the ancient cultures we teach) and also to engage broadly with the world/be aware of news and current events. I'd almost like to see a requirement in the arts and sciences curriculum that forces them to read newspapers!

Some of the students I have taught have absolutely no concept of how to behave in class so as to show respect to instructors and fellow students (specifically use of cellphones, talking in class) (page 215). So, if courtesy is a skill, then I think that it is important that it be taught somehow.

We continue to get students with poor writing and study skills as well as poor knowledge of how to utilize the library and on-line research resources. Additionally, students have a poor understanding of how to cite their sources within their assigned research papers. Time management is another area needing work. Without these skills students will not gain the most benefit from the classes they are taking. Further, the importance of getting good grades from the beginning is important to communicate up front from the perspective of future opportunities to attend graduate school. Students with less than a "B" average will find it difficult to be accepted into any Graduate Degree Program.

Reading/writing is sometimes a problem but in our department we, as a faculty, agree that we cannot teach these skills in addition to our own specialty skills. If they are lacking we encourage students to get more training in these areas from our university writing programs. We realize that there are potential problems with this approach, however, and do try to find a balance.

I am not currently teaching in higher education except for Summer ESL, so I cannot give a current answer.

Oral and communication skills.

Critical thinking is essential. All too often rote acceptance of the current thinking is condoned if not encouraged. Students should be directed to look critically at the evidence from that time period and to come to their own conclusions. Just because an opinion appears in print doesn't make it correct by default. Historians from past eras put their ideas forth based on their own frame of reference and the evidence known to them at that time. But new things come to light all the time and must be taken into consideration. In academia, we too frequently fall back onto the concepts developed by our predecessors and occasionally elevate these ideas to 'gospel'. But they may not always be complete, nor correct. Let's encourage students to THINK about the evidence and come to their own conclusions... they could be right. Afterall, the earth is Not flat and we are not the center of the solar system as was once believed.

Ability to work with others and relate academic to life skills.

critical understanding of new media 
Sad to say but: Basic study skills. Committment to one's coursework and a serious attitude about preparation for each class.

Students have really a chance of giving oral presentations only in the third year of their program. More emphasis should be put on writing skills.

\section{From one to ten, how would you rate your institution's scholarly level in comparison to other Universities nation-wide (page 216)? (1 being the best)}
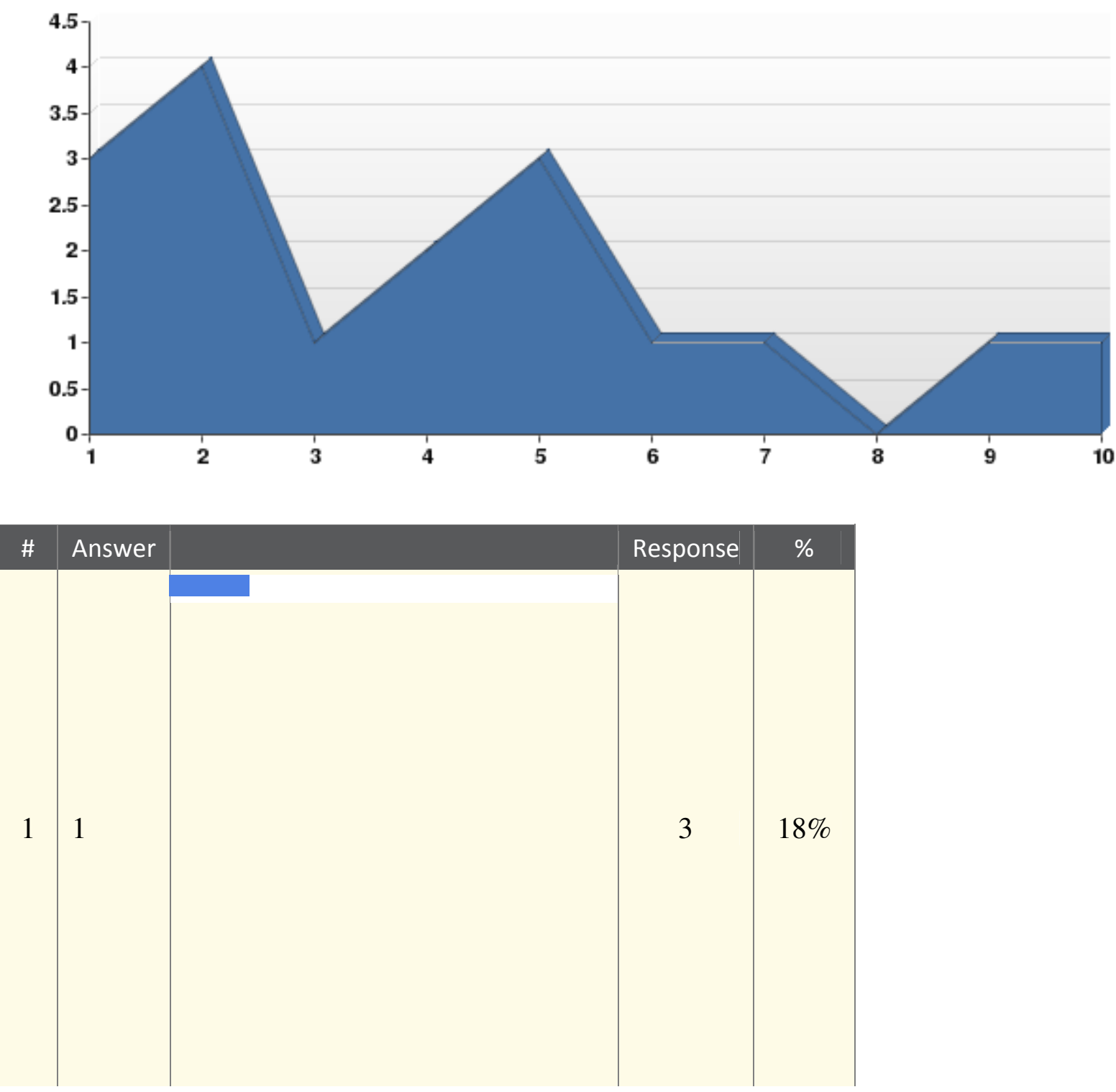

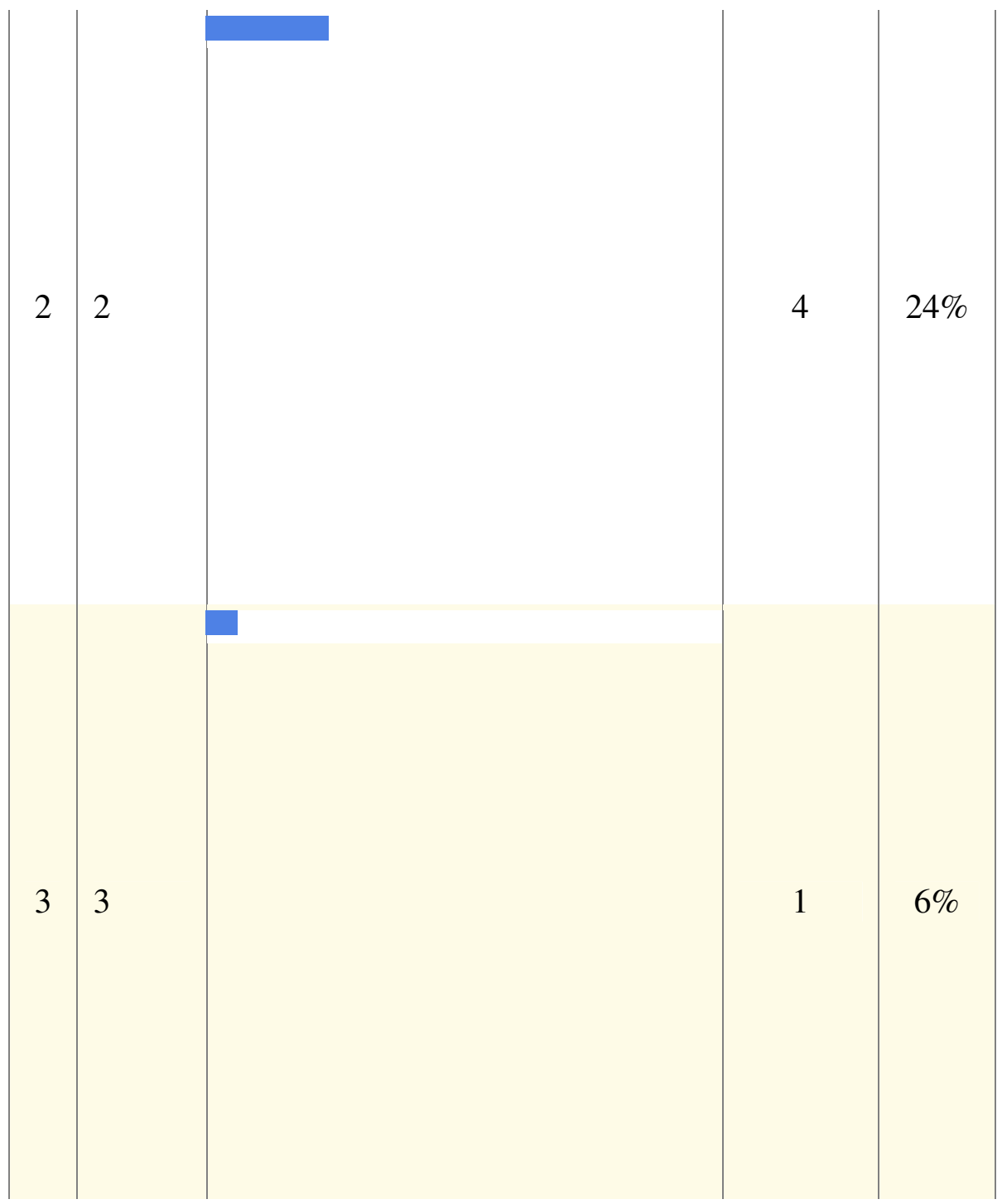

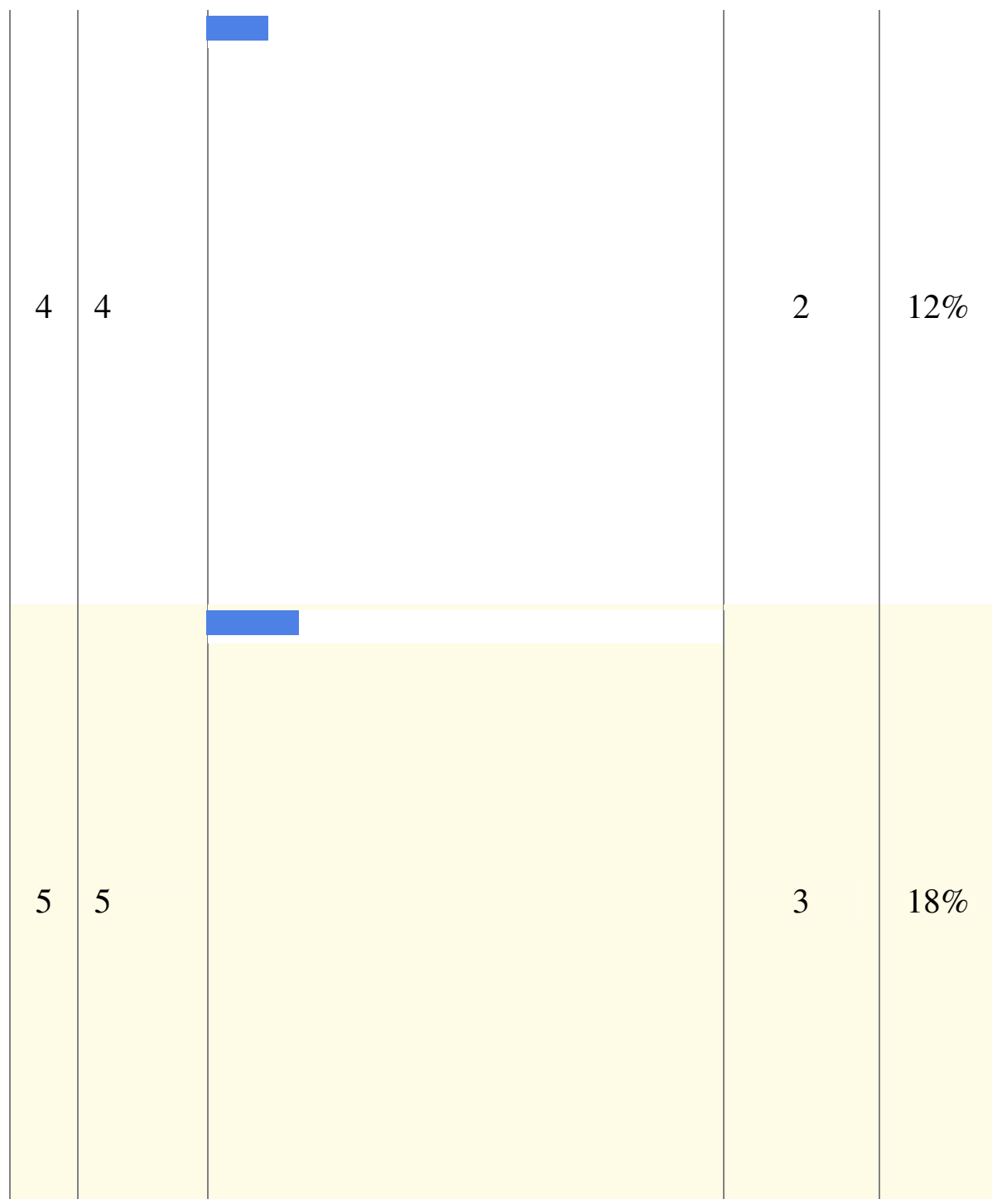

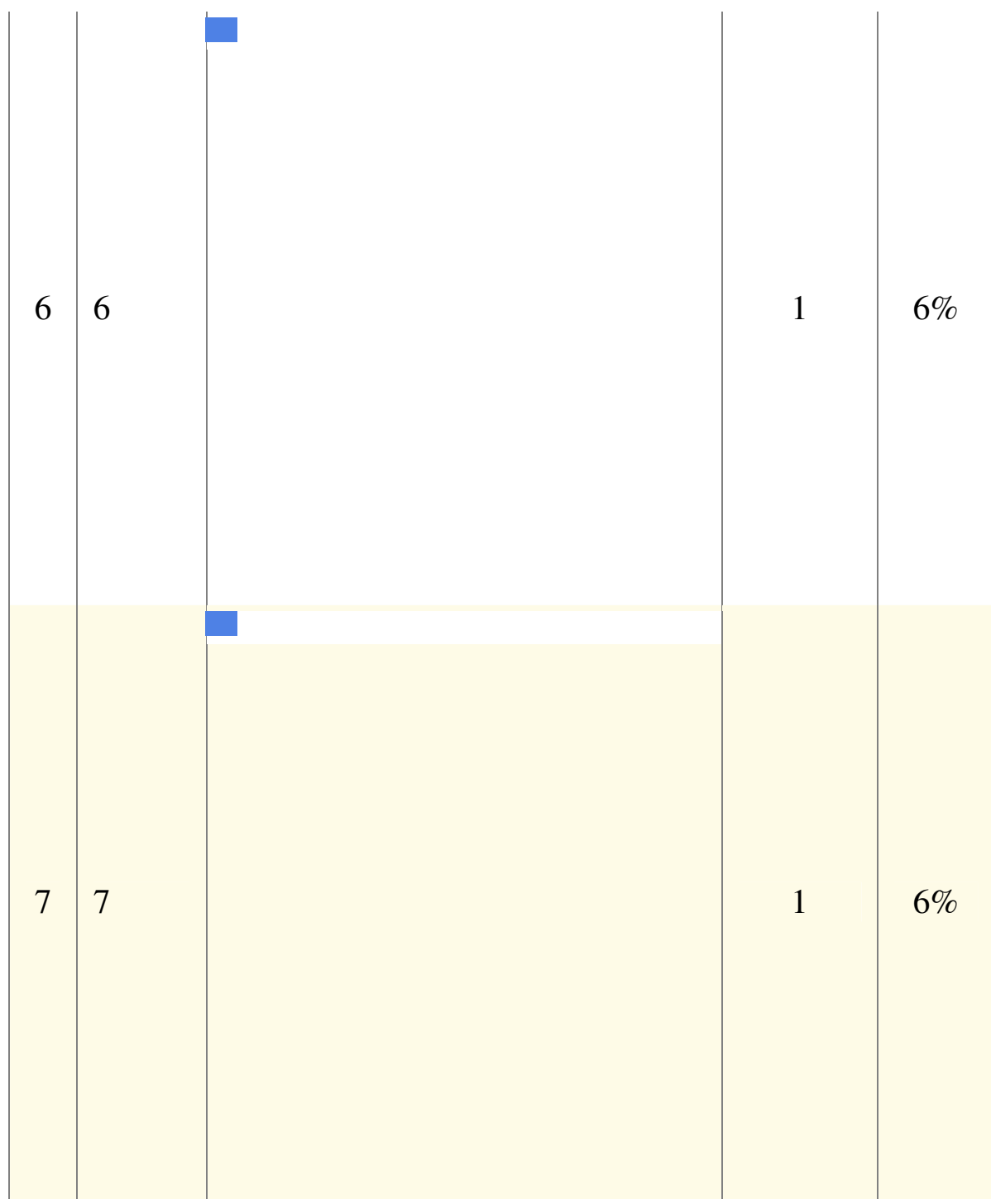

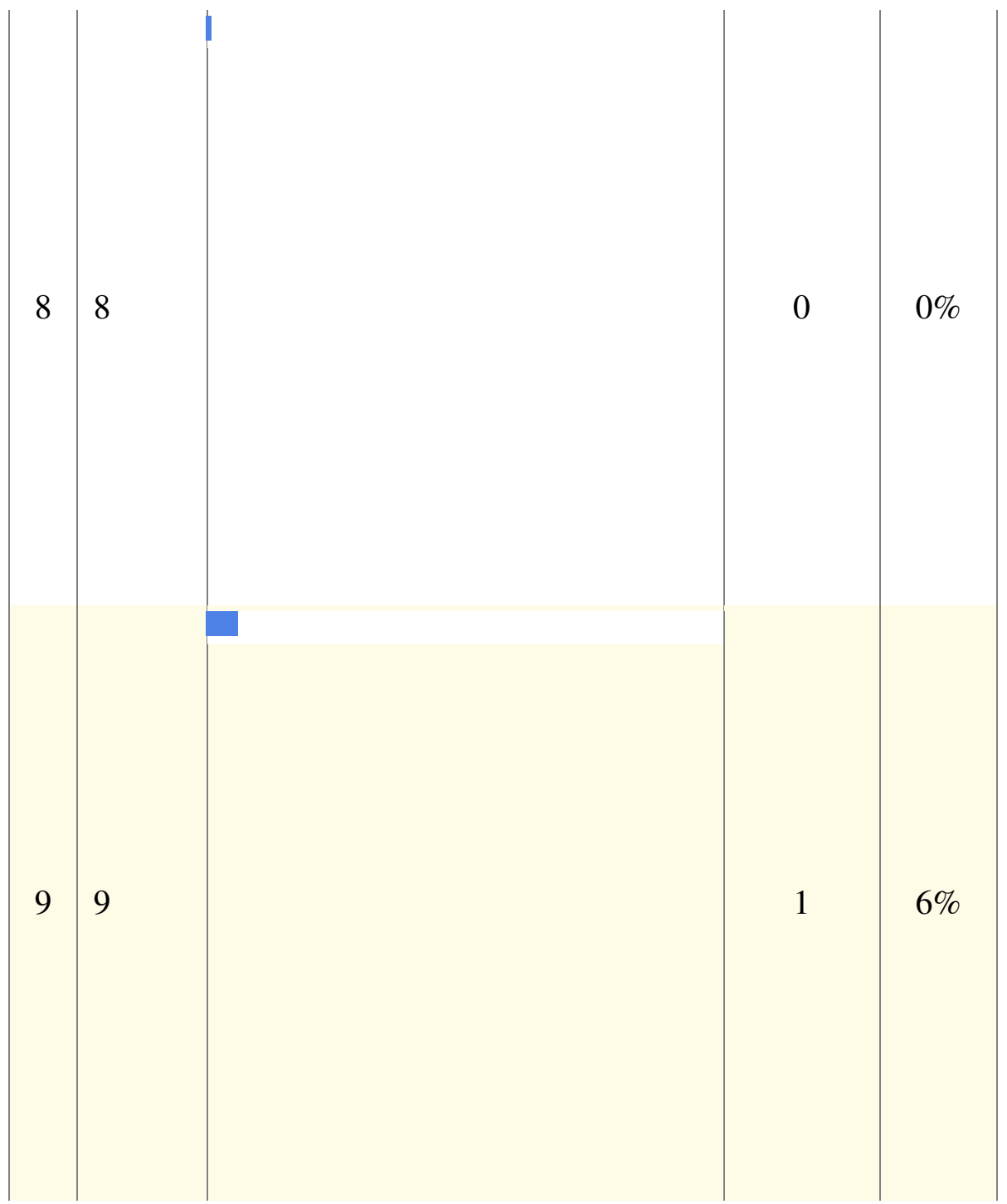


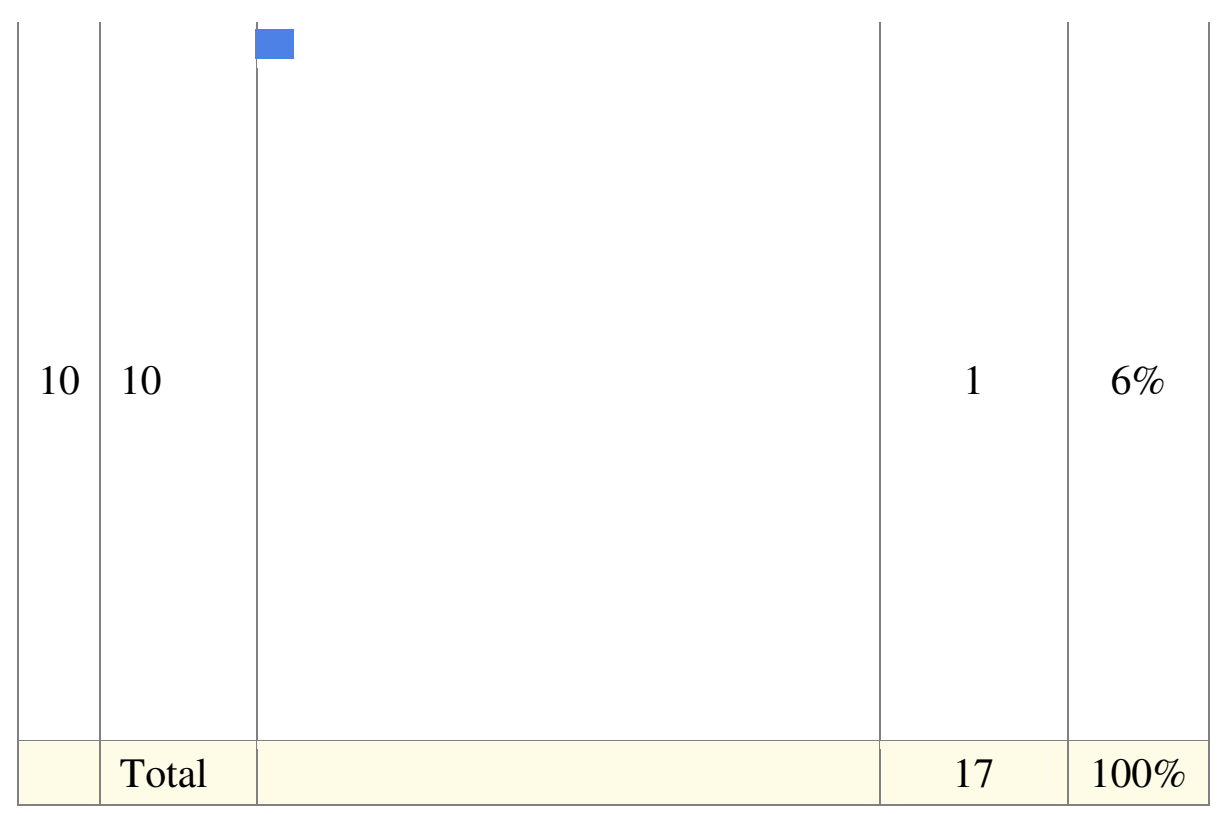

\section{Please rate the following based on the importance of students developing these abilities (page 217).}

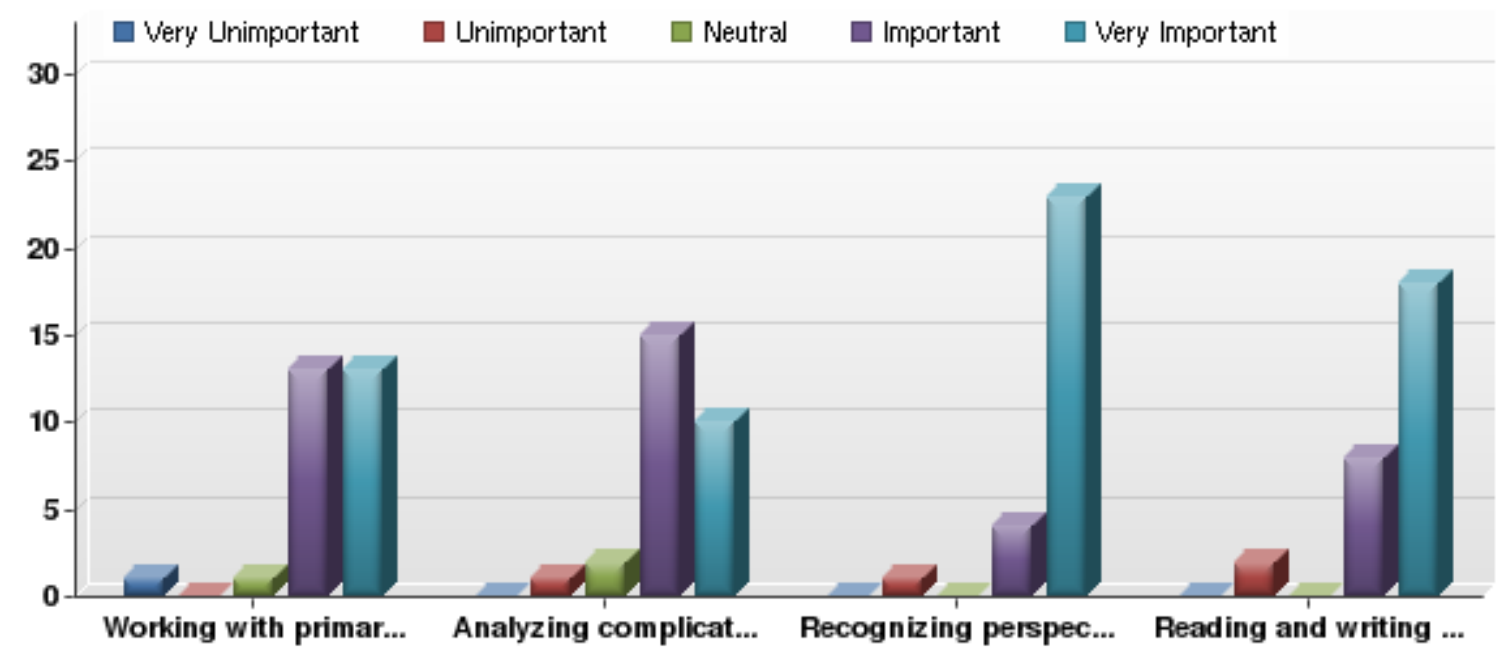

\begin{tabular}{|l|l|c|c|c|c|c|c|c|}
\hline \# & $\begin{array}{c}\text { Very } \\
\text { Qnimportan } \\
\mathrm{t}\end{array}$ & $\begin{array}{c}\text { Unimportan } \\
\mathrm{t}\end{array}$ & $\begin{array}{c}\text { Neutra } \\
\mathrm{I}\end{array}$ & $\begin{array}{c}\text { Importan } \\
\mathrm{t}\end{array}$ & $\begin{array}{c}\text { Very } \\
\text { Importan } \\
\mathrm{t}\end{array}$ & $\begin{array}{c}\text { Response } \\
\mathrm{s}\end{array}$ & Mean \\
\hline 1 & $\begin{array}{l}\text { Working } \\
\text { with } \\
\text { primary }\end{array}$ & 1 & 0 & 1 & 13 & 13 & 28 & 4.32 \\
\hline
\end{tabular}




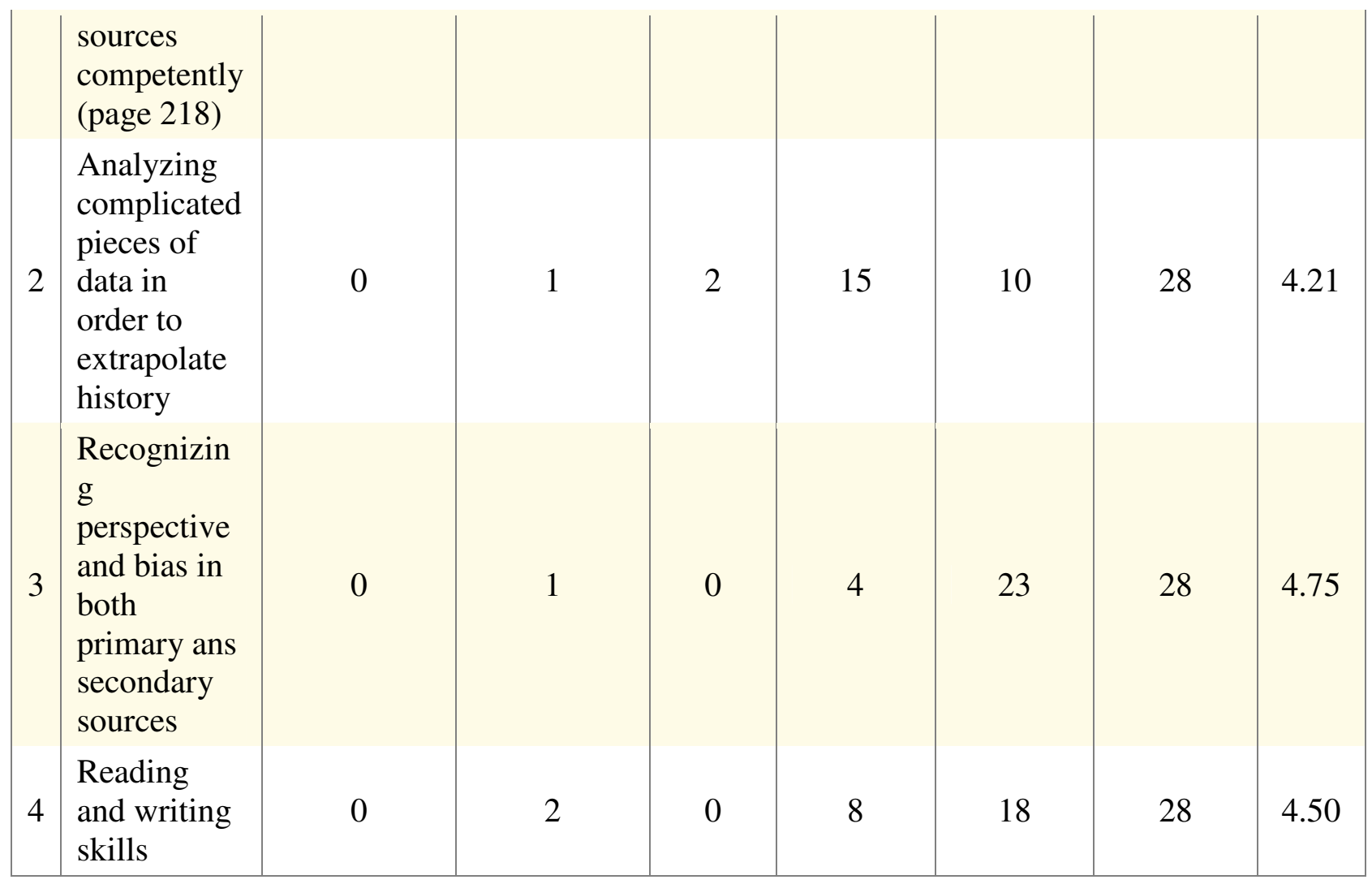

\begin{tabular}{|l|c|c|c|c|}
\hline Statistic & $\begin{array}{c}\text { Working with } \\
\text { primary sources } \\
\text { competently }\end{array}$ & $\begin{array}{c}\text { Analyzing complicated } \\
\text { pieces of data in order } \\
\text { to extrapolate history }\end{array}$ & $\begin{array}{c}\text { Recognizing perspective } \\
\text { and bias in both primary } \\
\text { ans secondary sources }\end{array}$ & $\begin{array}{c}\text { Reading } \\
\text { and writing } \\
\text { skills }\end{array}$ \\
\hline Mean & 4.32 & 4.21 & 4.75 & 4.50 \\
Variance & 0.74 & 0.54 & 0.42 & 0.70 \\
Standard & 0.86 & 0.74 & 0.65 & 0.84 \\
Deviation & 28 & 28 & 28 & 28 \\
Total & & & & 28 \\
Responses & & 28 & & 28 \\
\hline
\end{tabular}

\section{Does your department have a defined set of outcome objectives for its undergraduate majors (page 219)?}



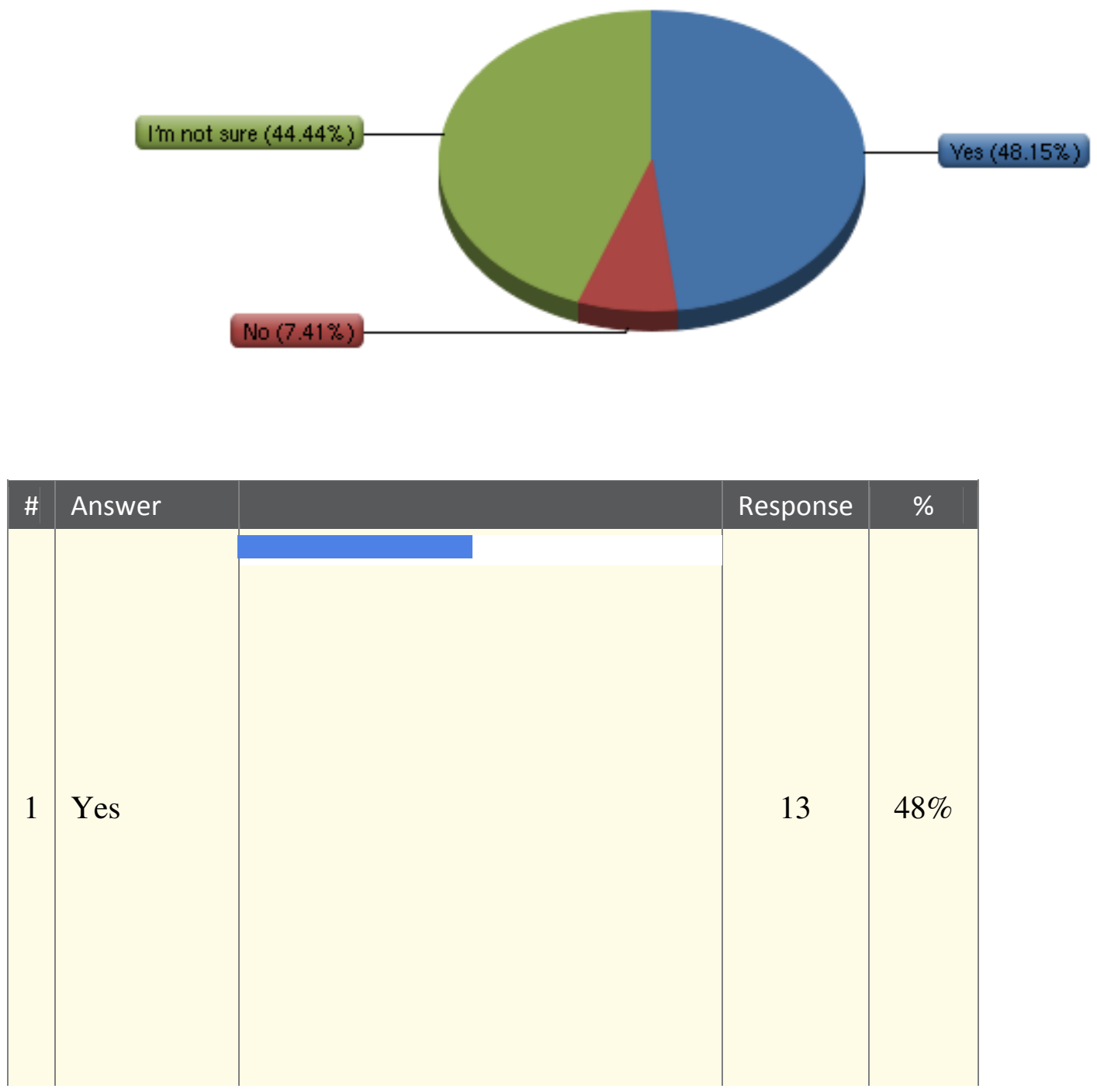


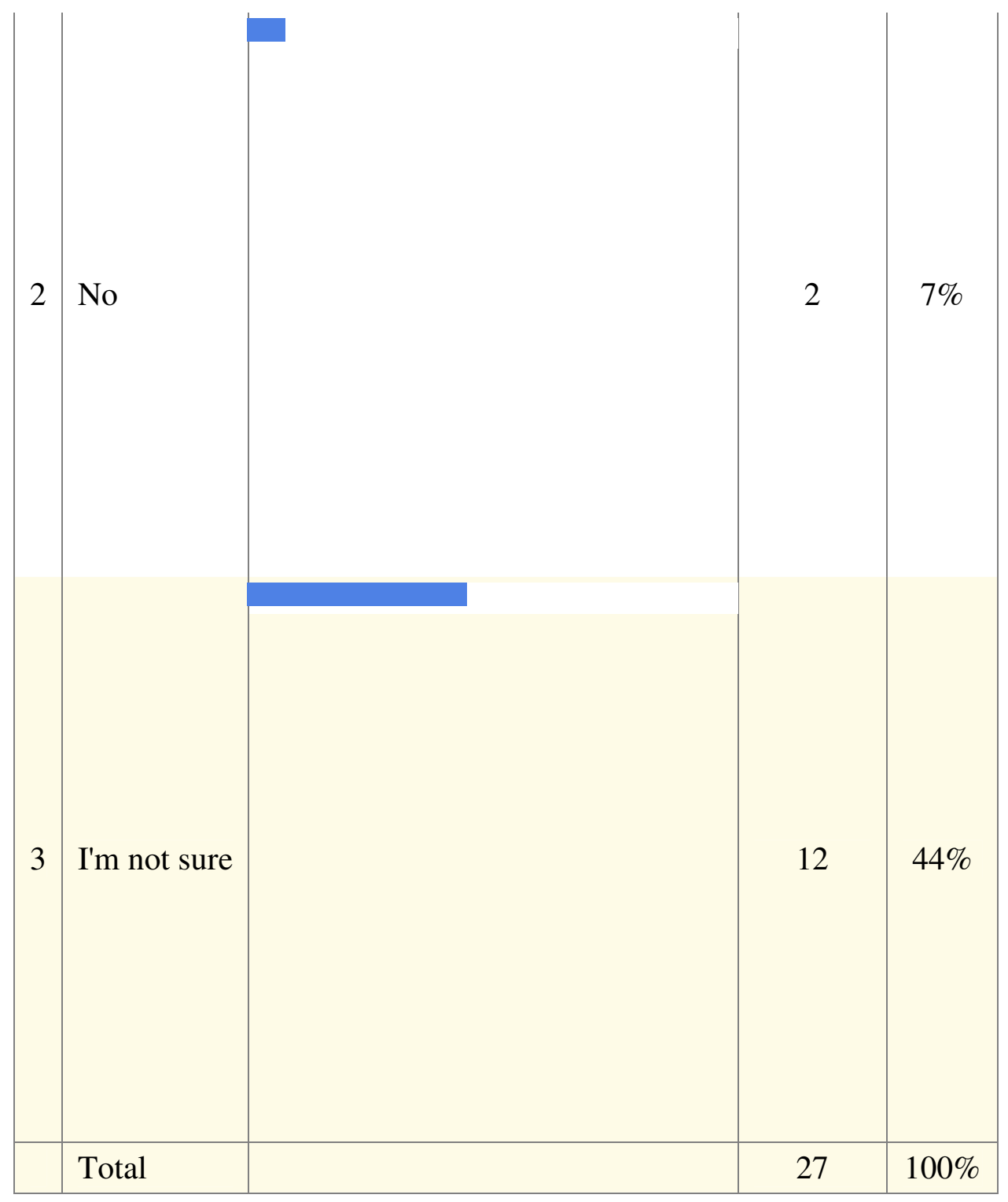

7. Which of the following options do you feel closely relates to the objectives defined by your department: (Check all that apply) (page 220). 

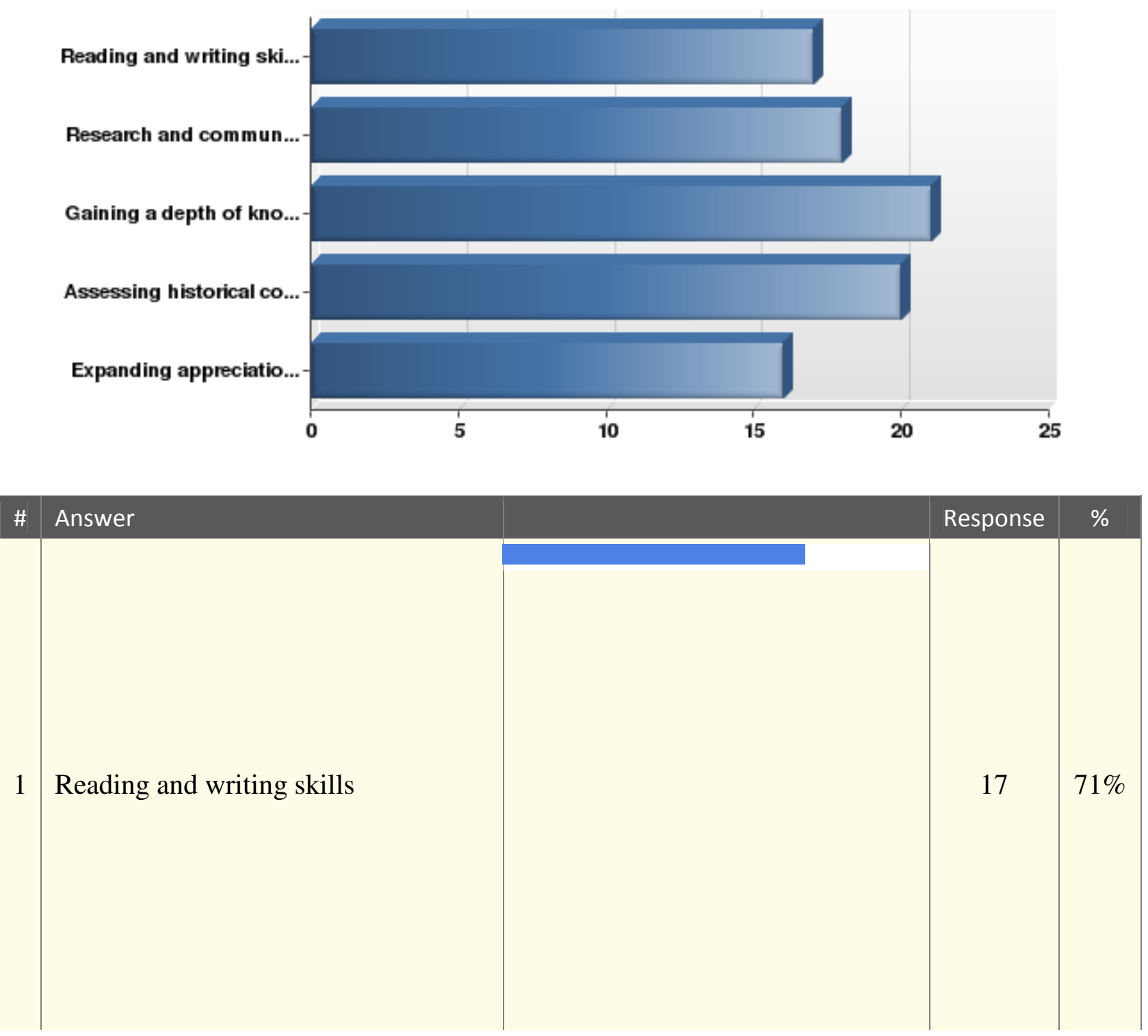
2 Research and communication skills

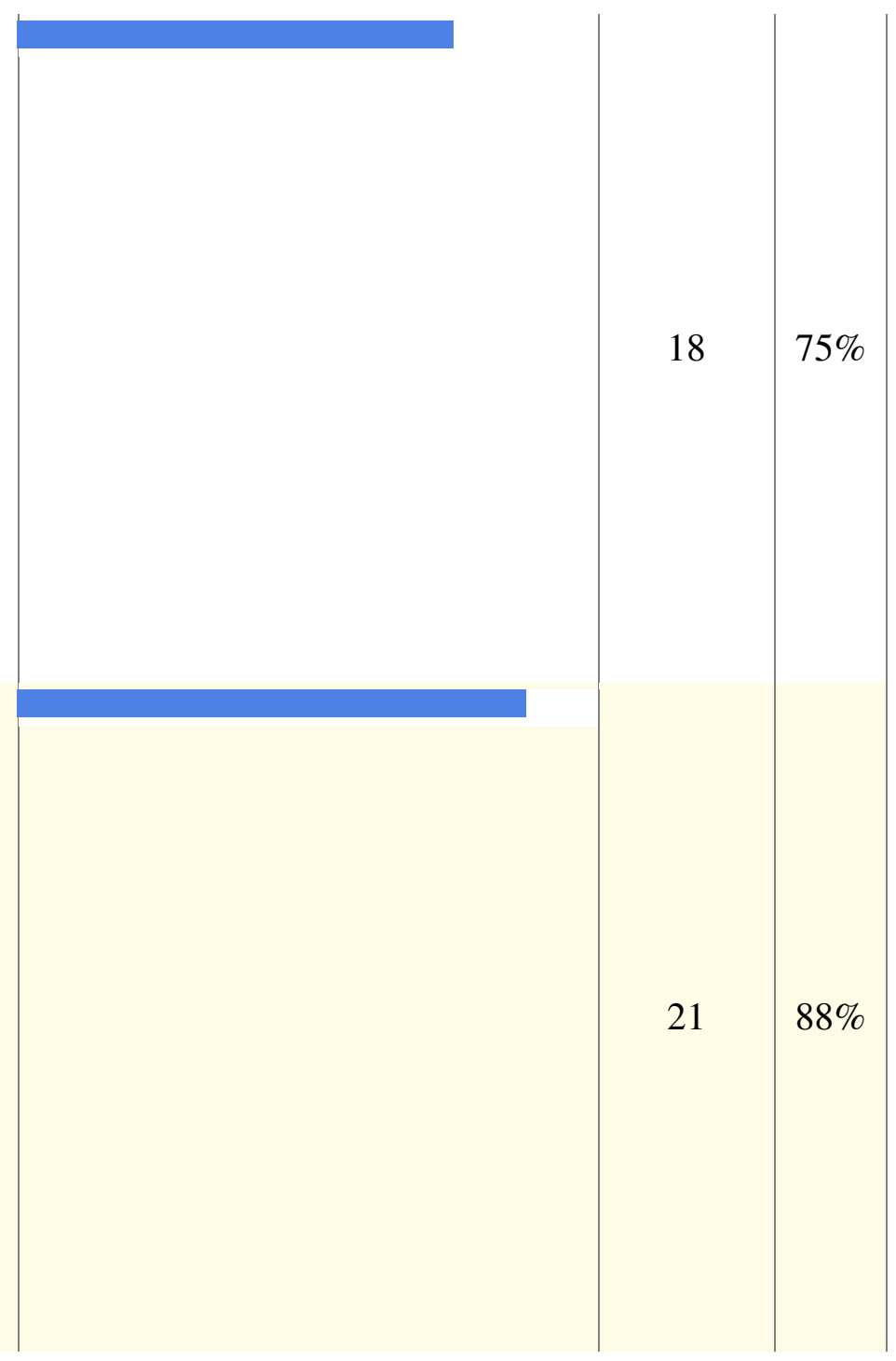

3 Gaining a depth of knowledge of a particular time-period 
Assessing historical context and

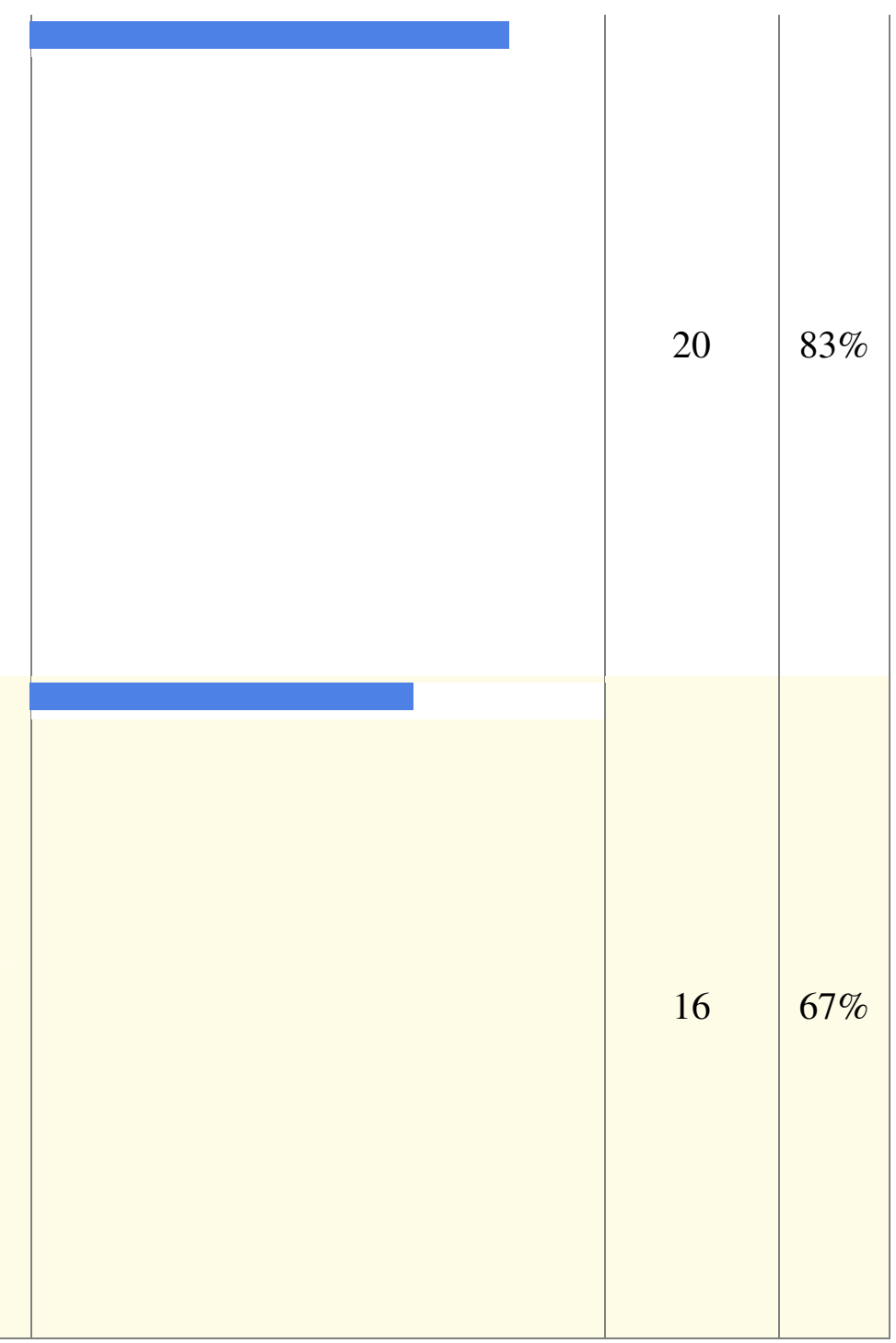

5 Expanding appreciation and understanding for past cultures

8. The teachers in my department have a parallel focus and are working to establish the same goals (page 221). 

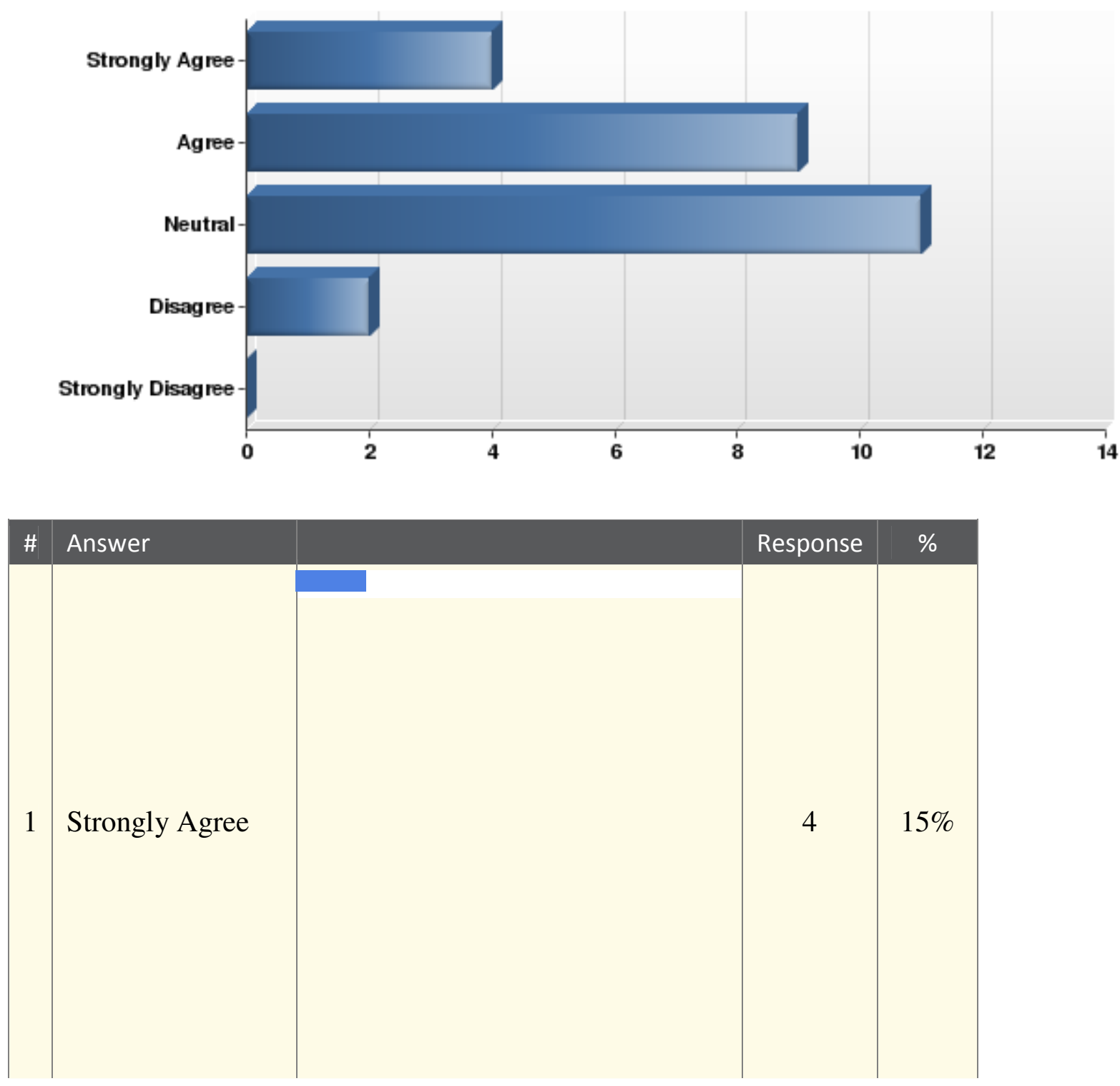


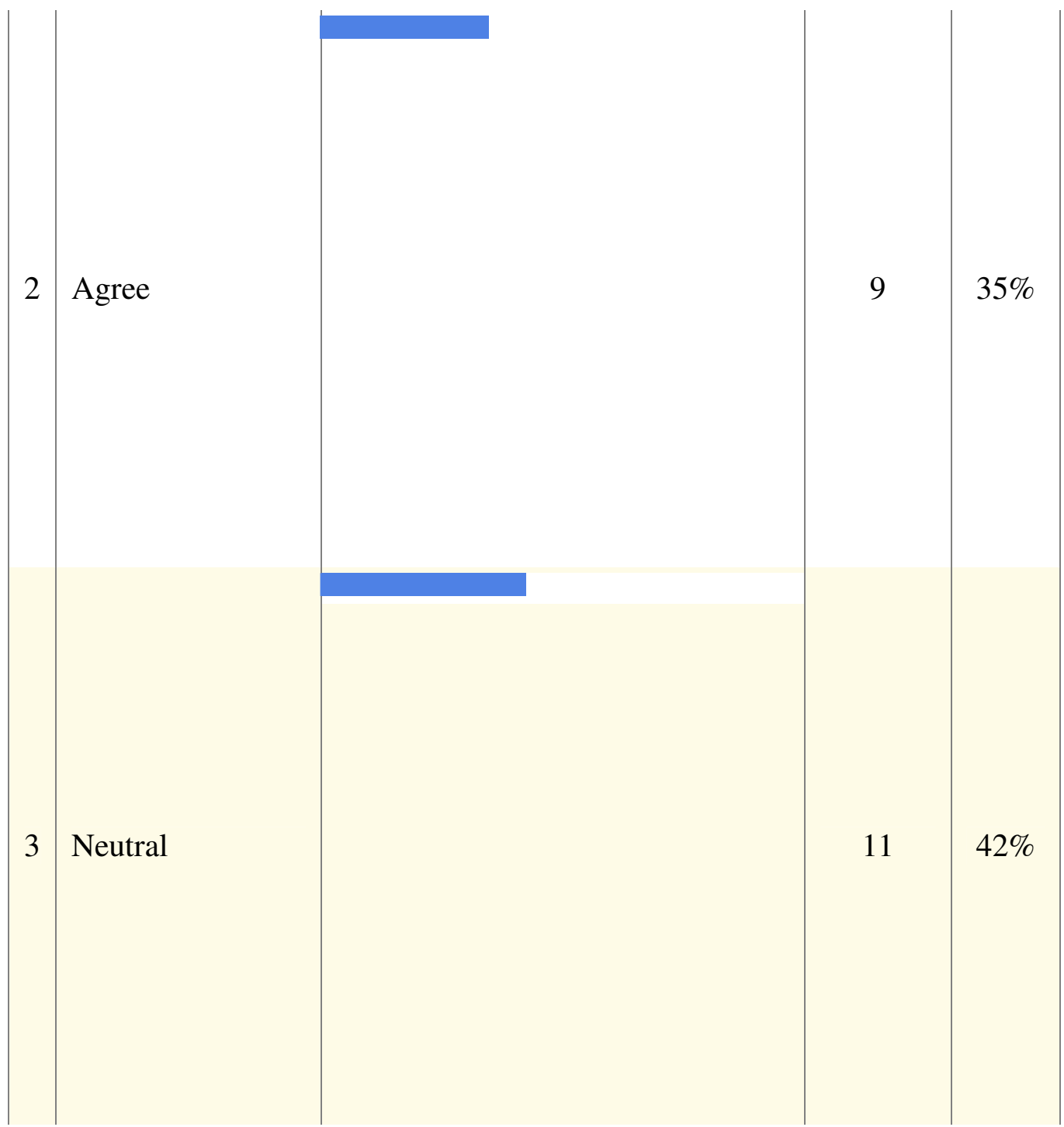




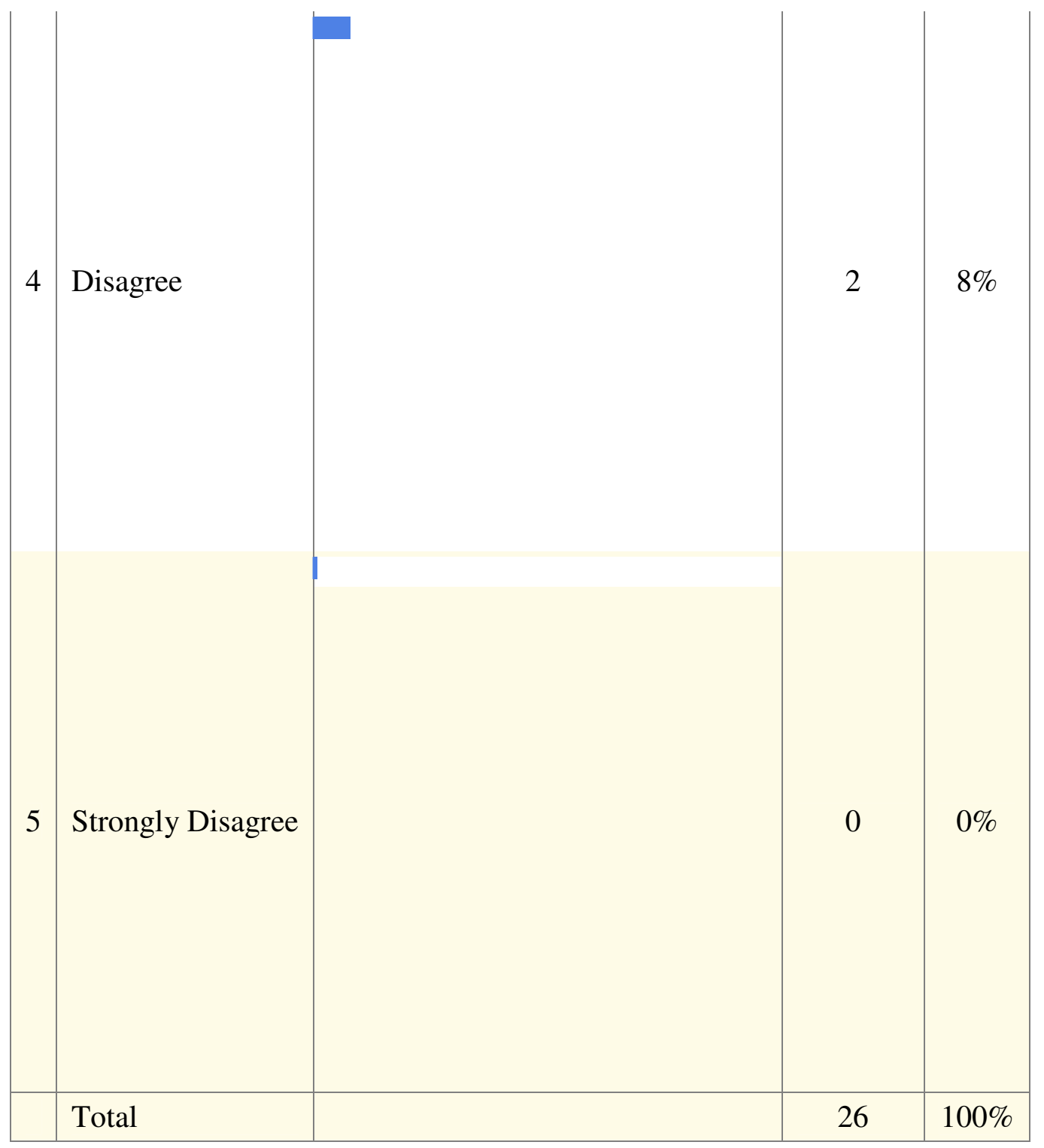

\section{If you could add an outcome objective for your Egyptian history students, what would it be (page 222)?}

\section{Text Response}

More general, comperative training that enables them to get jobs outside Egyptology, for example in Ancient History or Classics.

language skills

Students should be able to analyze and synthesize various types of information to create their own interpretation of Egyptian history. 
To develop a sensitivity and tolerance to other cultures both modern and ancient.

Ability to contextualize Egyptian history within the broader geographic region.

A real appreciation of time-depth

Seeing Egypt in a larger geographical context, including ancient Africa.

The outcomes listed above seem to cover our own goals.

I have left most of this survey blank, because I am not currently teaching at a college or university except for Summer ESL programs and I am not currently teaching ancient Egyptian history.

Learn to do independent research and present it effectively to their peers.

I want students to be able to look past the biases of our scholars from bygone eras. Prejudices and condemnations of particular historical characters / time periods are a case in point.

Akhenaten was deemed a 'heretic' and reviled for not supporting the 'traditional' gods and even expunging their names from monuments etc. However, those that came after him destroyed his great works and vilified him to a much greater extent than He ever did to his opponents during his lifetime. However, Akhenaten remains forever in the texts as a 'criminal' while those that razed his works and restored the corrupt status quo of the Amun priesthood are gifted with praise as 'restoreres'. The early historians were doubtlessly swayed by the odd art and dramatic actions of this maverick pharaoh and applied unflattering comments to assessments of his reign. How sad that these 'scholars' let their own prejudices creep into their work and even more so that we, as teachers, continue to follow the 'party line' and condemn this monotheist who promoted a god not unlike the God of Judeo-Christian beliefs that is accepted worldwide. Let's encourage our students to be realists and think for themselves and question some of the outmoded 'scholarly' ideas of past eras.

Understating time periods across cultures.

Understanding and critically assessing aspects of new media (e.g. internet sources), such as authority and authorship, visual culture, mapping and GIS (page 223).

A general understanding of chronology and culture, including how it relates to things taking places in other parts of the greater Near East/Old World.

Appreciating ancient Egypt as primarily an African civilization.

\section{If you could add or delete an outcome objective for your Egyptian history students, what would it be?}

\section{Text Response}

Nothing

don't know

Focus on unimportant minutiae. 
Rote acceptance.

None

$-$

0

Seeing ancient Egypt as primarily a Near Eastern civilization.

\section{Please list in order of importance what the two main objectives should be for an Egyptian history class}

\section{Text Response}

1. Overview on the Egyptian history and to see and understand Egypt in comparison with the other cultures of the Ancient Mediterranean/Near East. 2. Getting familiar with the sources.

Ability to understand the context and biases of the sources Ability to work with the sources 1- To understand the progression of events and themes that make up Egyptian history 2- to look for ways in which that understanding can be deepened through interaction with primary sources

To learn to use primary resources to understand the past, and to understand the problems inherent with dealing with incomplete data. To learn to question and read critically (page 224).

1. To develop an understanding Egyptian society within the the context of the surrounding region, at various historical time periods. 2. To provide training in the skills needed to conduct informed research utilizing both primary and secondary sources.

Understanding the structure of Egyptian history Understanding how archaeological remains fit into that structure

To learn something about what we know of Egyptian history and how it is that we know it. To learn something about what we do not know about ancient Egypt and why we either do not or cannot know it.

1. A good general overview of pharaonic Egyptian history and culture 2. The ability to place this knowledge in a larger context

1) Critical thinking and analysis of primary and secondary sources 2) (this is affected by the fact that our own students have an archaeology focus rather than a pure history focus): The ability to relate primary sources and materials to the wider purview of the area of research - and beyond, where possible.

Knowledge in context (both cultural and intercultural context, including interactions). Being conversant with original sources and their critical study, and with scholarly literature. Depending on the level of the class, the sources might have to be in translation and some scholarly literature might be inaccessible because of limitations in modern language knowledge.

Learn how to do independent research. Present independent research effectively to the class. See earlier comments. 
Having a grasp of the basic events in a timeline. Understanding how to work with primary sources.

Understanding the biases of different sources Combining sources and approaches to gain an understanding of history

training in critical analysis of multi-disciplinary sources training in a historiographical approach to secondary sources and modern scholarly analysis of Ancient Egyptian evidence.

A general knowledge of Egyptian history from prehistory to perhaps the spread of Islam. An understanding of the nature by which ancient documents are assessed and then presented.

to be able to understand the main cultural, religious and political trends that took place over the course of 3000 years of Egyptian history. to be able to see the divergence and convergence between pharaoniccivilisation and other ancient near eastern societies (Mesopotamia, Phoenicia, Ancient Israel, etc.) (page 225).

Situate Egypt as an African civilization in the context of the cultures surrounding it. Connect the rise and development of Egyptian civilization to larger issues like the origins of agriculture, rise of the state, power and ideology, gender, etc.

\section{Please respond to the following statements as to their importance to teaching Egyptian history:}

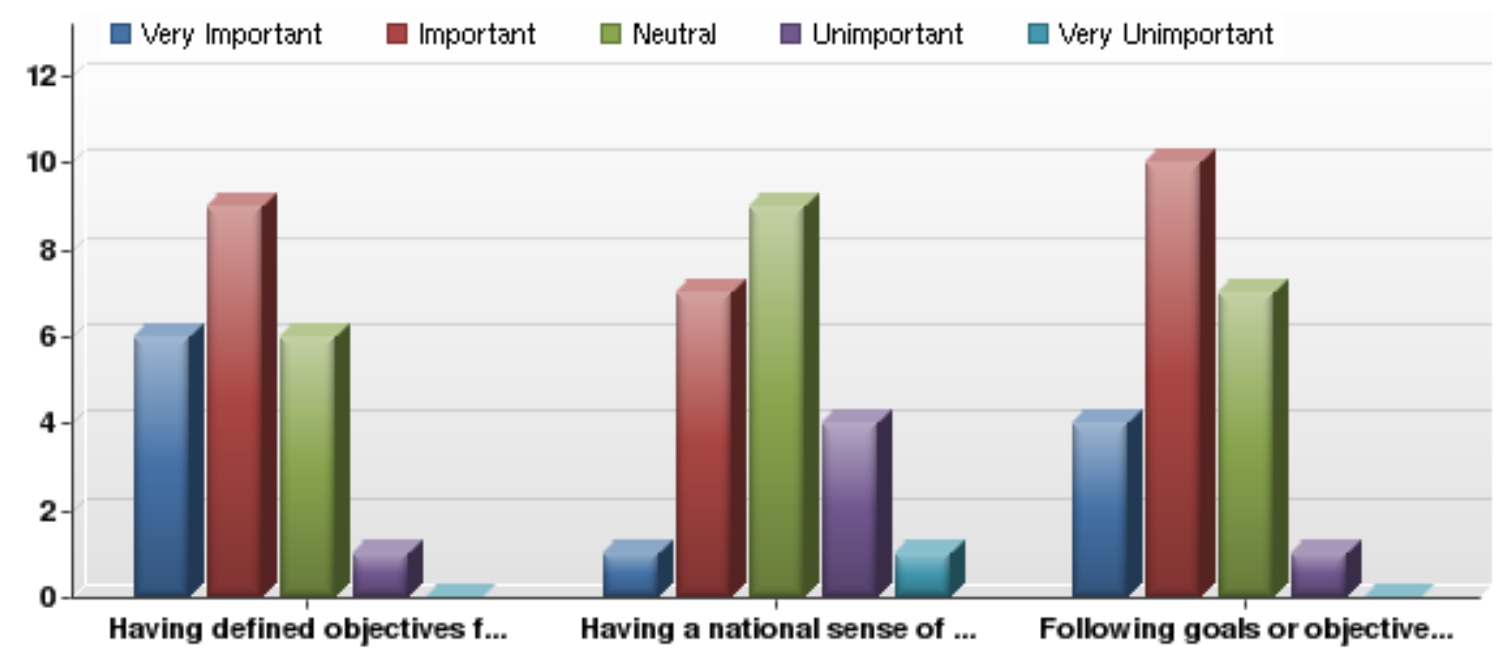

\begin{tabular}{|c|c|c|c|c|c|c|c|c|}
\hline \# & Question & $\begin{array}{c}\text { Very } \\
\text { Importan } \\
\mathrm{t}\end{array}$ & $\begin{array}{c}\text { Importan } \\
\mathrm{t}\end{array}$ & $\begin{array}{c}\text { Neutra } \\
\text { I }\end{array}$ & $\begin{array}{c}\text { Unimportan } \\
\mathrm{t}\end{array}$ & $\begin{array}{c}\text { Very } \\
\text { Unimportan } \\
\mathrm{t}\end{array}$ & $\begin{array}{c}\text { Response } \\
\mathrm{s}\end{array}$ & Mean \\
\hline 1 & $\begin{array}{l}\text { Having } \\
\text { defined }\end{array}$ & 6 & 9 & 6 & 1 & 0 & 22 & 2.09
\end{tabular}




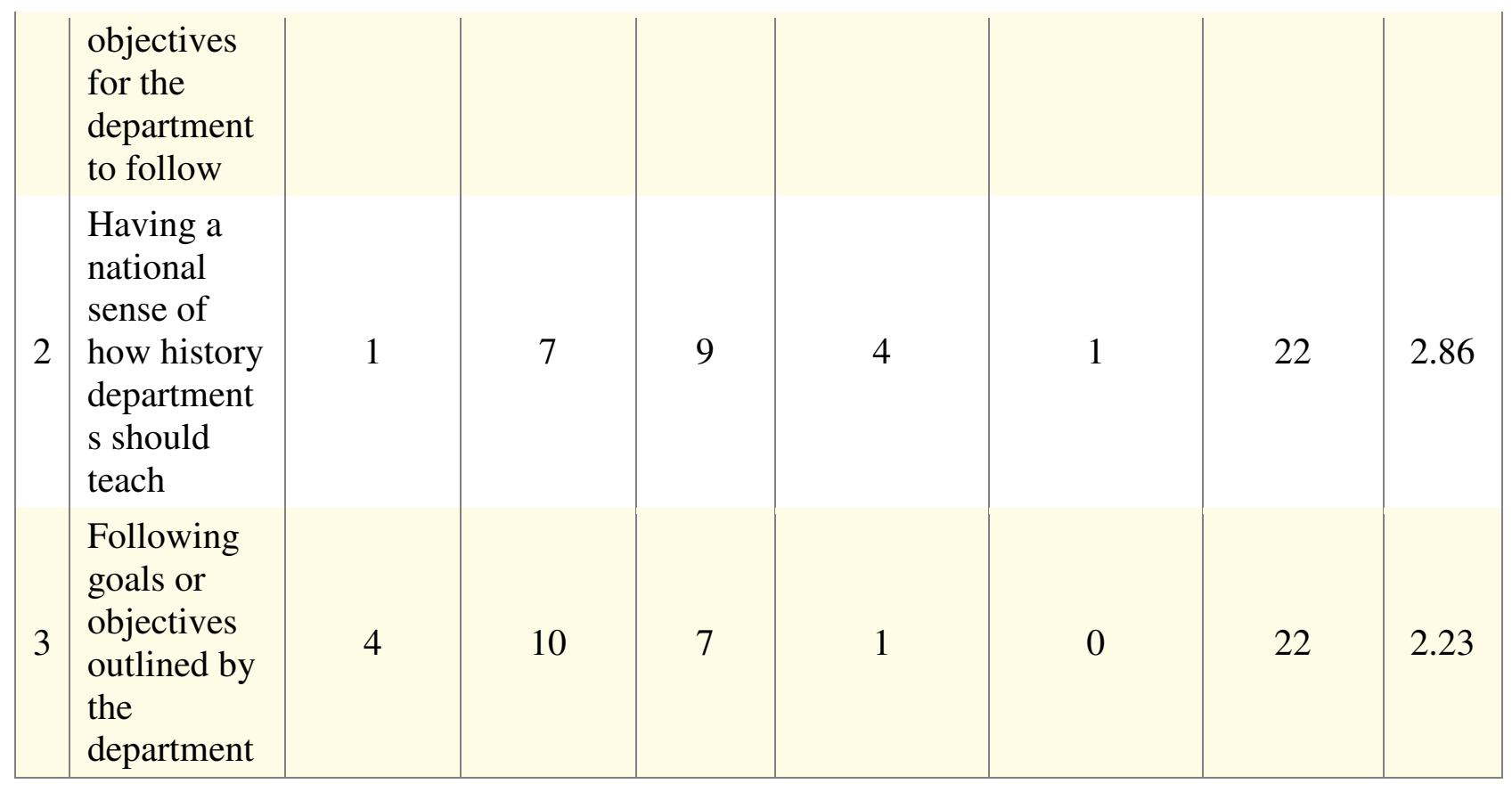

\begin{tabular}{|l|c|c|c|}
\hline Statistic & $\begin{array}{c}\text { Having defined objectives } \\
\text { for the department to } \\
\text { follow }\end{array}$ & $\begin{array}{c}\text { Having a national sense of } \\
\text { how history departments } \\
\text { should teach }\end{array}$ & $\begin{array}{c}\text { Following goals or } \\
\text { objectives outlined by the } \\
\text { department }\end{array}$ \\
\hline Mean & 2.09 & 2.86 & 2.23 \\
Variance & 0.75 & 0.89 & 0.66 \\
Standard & 0.87 & 0.94 & 0.81 \\
Deviation & 22 & 22 & 22 \\
Total & & & \\
Responses & 22 & & \\
\hline
\end{tabular}

\section{Please respond to the following statements based on your teaching experience (226):}




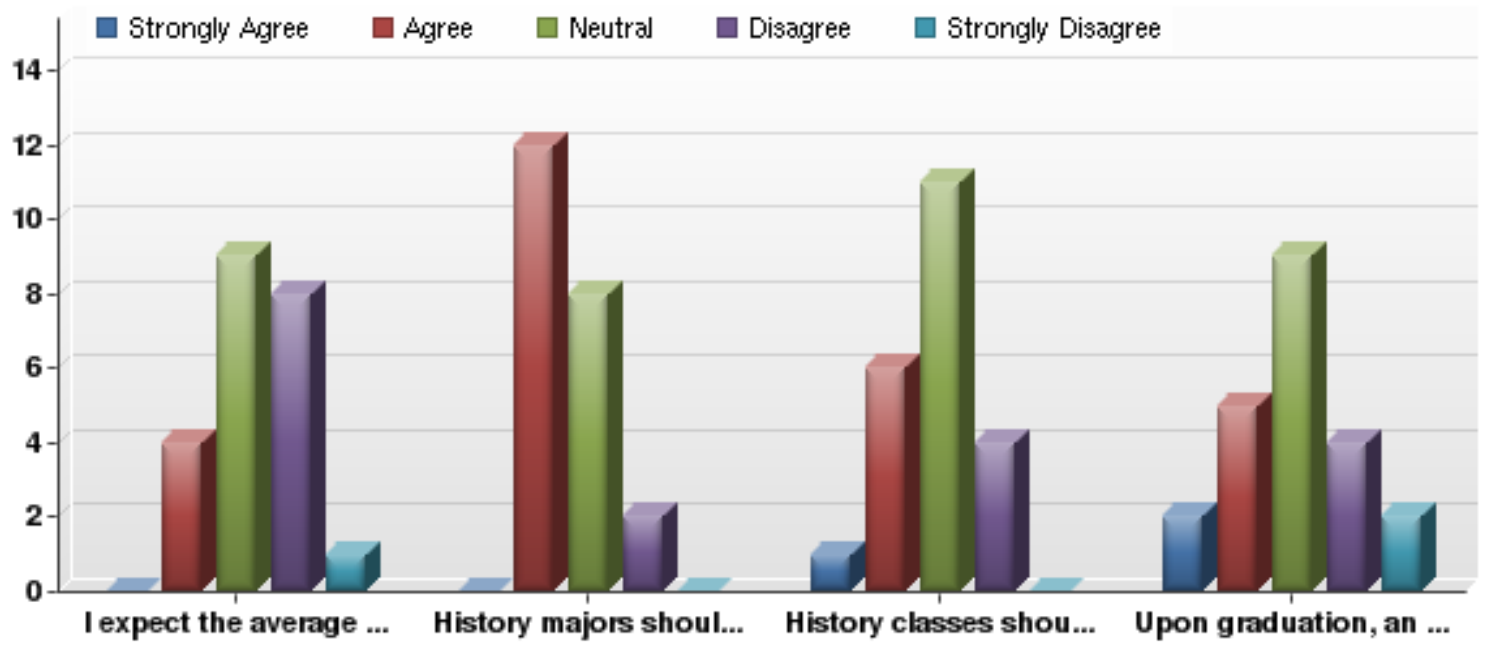

\begin{tabular}{|c|c|c|c|c|c|c|c|c|}
\hline$\#$ & Question & $\begin{array}{c}\text { Strongly } \\
\text { Agree }\end{array}$ & Agree & Neutral & Disagree & $\begin{array}{l}\text { Strongly } \\
\text { Disagree }\end{array}$ & Responses & Mean \\
\hline 1 & $\begin{array}{l}\text { I expect the average } \\
\text { undergraduate history } \\
\text { major to attend } \\
\text { graduate school }\end{array}$ & 0 & 4 & 9 & 8 & 1 & 22 & 3.27 \\
\hline 2 & $\begin{array}{l}\text { History majors should } \\
\text { be encouraged to attend } \\
\text { graduate school }\end{array}$ & 0 & 12 & 8 & 2 & 0 & 22 & 2.55 \\
\hline 3 & $\begin{array}{l}\text { History classes should } \\
\text { encourage students to } \\
\text { become practicing } \\
\text { historians (page } 227 \text { ). }\end{array}$ & 1 & 6 & 11 & 4 & 0 & 22 & 2.82 \\
\hline 4 & $\begin{array}{l}\text { Upon graduation, an } \\
\text { undergraduate student } \\
\text { of history would have } \\
\text { adequate training to } \\
\text { work as a historian }\end{array}$ & 2 & 5 & 9 & 4 & 2 & 22 & 2.95 \\
\hline
\end{tabular}

\begin{tabular}{|c|c|c|c|c|}
\hline Statistic & $\begin{array}{l}\text { I expect the average } \\
\text { undergraduate } \\
\text { history major to } \\
\text { attend graduate } \\
\text { school }\end{array}$ & $\begin{array}{l}\text { History majors } \\
\text { should be } \\
\text { encouraged to } \\
\text { attend graduate } \\
\text { school }\end{array}$ & $\begin{array}{l}\text { History classes } \\
\text { should } \\
\text { encourage } \\
\text { students to } \\
\text { become } \\
\text { practicing } \\
\text { historians }\end{array}$ & $\begin{array}{l}\text { Upon graduation, an } \\
\text { undergraduate student } \\
\text { of history would have } \\
\text { adequate training to } \\
\text { work as a historian }\end{array}$ \\
\hline
\end{tabular}




\begin{tabular}{|l|l|l|l|l|} 
Mean & 3.27 & 2.55 & 2.82 & 2.95 \\
Variance & 0.68 & 0.45 & 0.63 & 1.19 \\
Standard & 0.83 & 0.67 & 0.80 & 1.09 \\
Deviation & & & & 22 \\
Total & 22 & 22 & 22 & \\
Responses & & & & \\
\hline
\end{tabular}

\section{Which of the following best describes the geographical location of} your institution (page 228)?
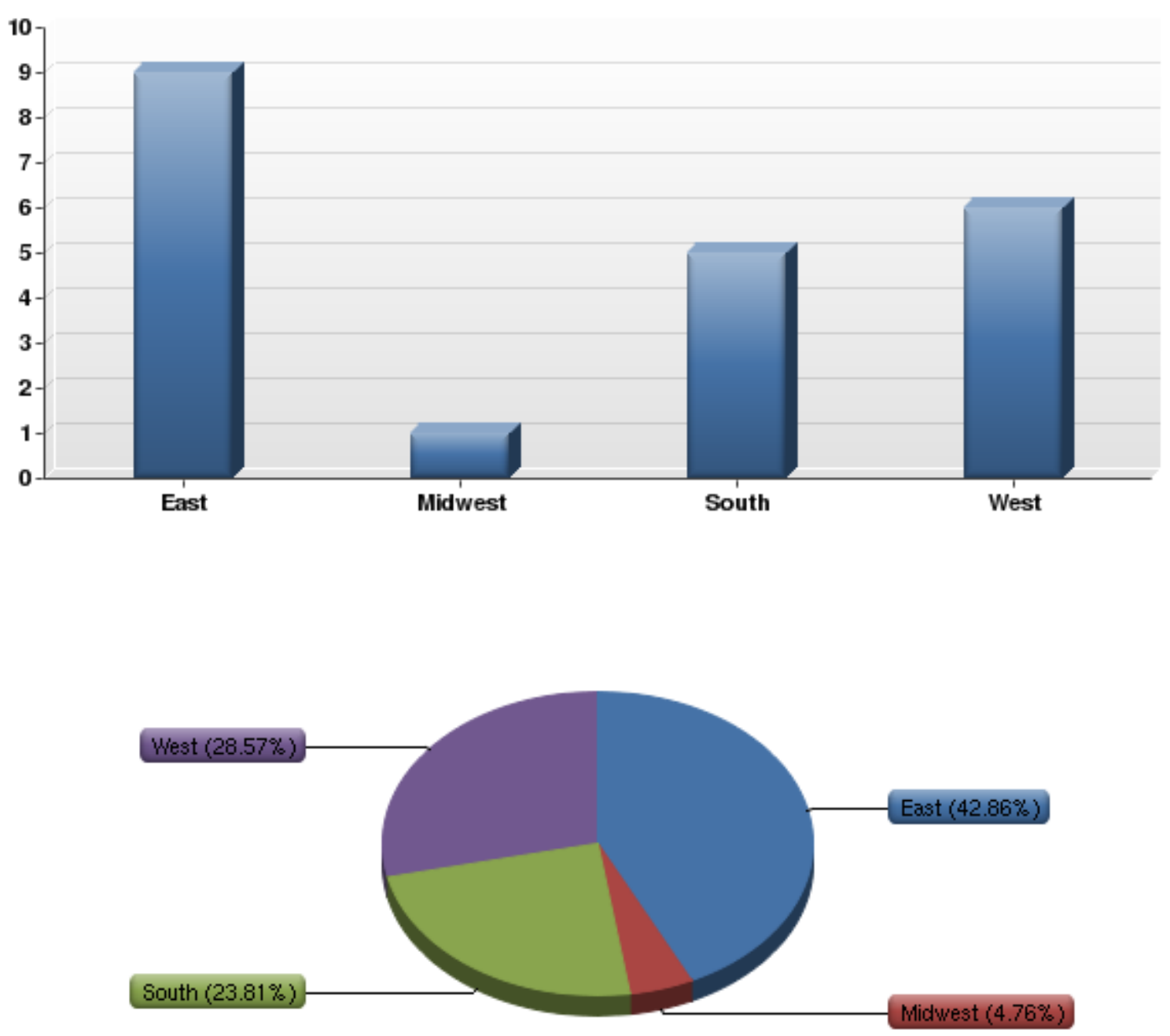


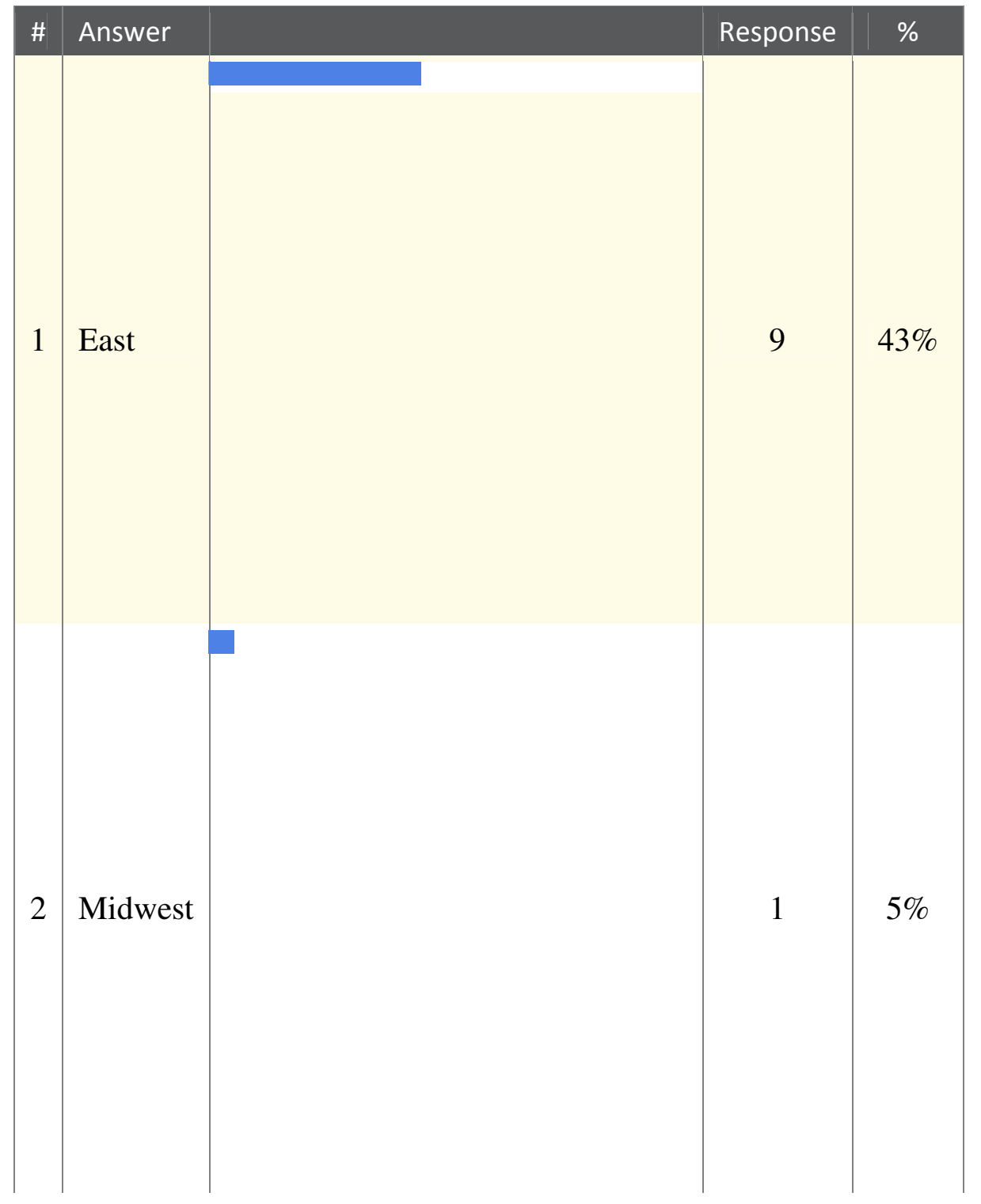




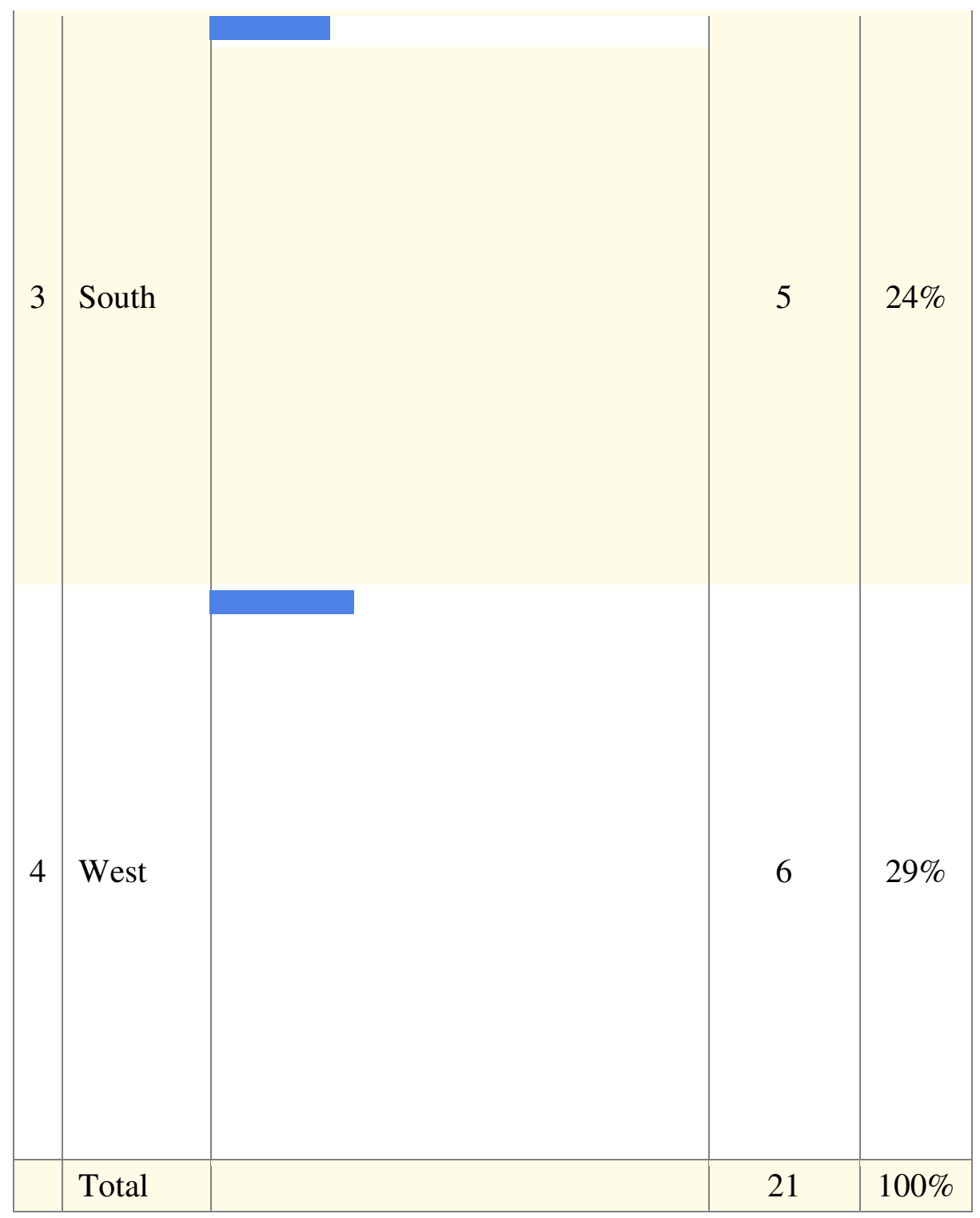


Page 229

Bibliography

Alabama University, The History Department's goals, http://www.utah.edu/portal/site/uuhome/, found on March 20, 2008.

Assmann, Jan. "Inscriptional Violence and the Art of Cursing: A Study of Performative Writing." Stanford Literature Review 9, no. 1 (1992): 43-65.

. "When Justice Fails: Jurisdiction and Imprecation in Ancient Egypt and the Near East." JEA 78 (1992): 149-162.

. The Mind of Egypt: History and Meaning in the Time of the Pharaohs. Translated by Andrew Jenkins. New York: Metropolitan Books, 2002.

Astin, Alexander. Assessment for Excellence. The Philosophy and Practice of Assessment and Evaluation in Higher Education. New York: American Council on Education and Macmillan Publishing Company, 1991.

Banta, Trudy W., Jon P. Lund, Karen E. Black, and Frances W. Oblander, Assessment in Practice. Putting Principles to Work on College Campuses. San Francisco: Jossey-Bass Publishers.

Biggs, John. "Assessing for Quality in Learning." In Assessment to Promote Deep Learning, ed. Linda Suskie, 66-67. Washington DC: American Association for Higher Education, 2001.

Bloch, Marc. The Historian's Craft. Translated by Peter Putnam. New York: Alfred A. Knopf, 1953. 
Braudel, Fernand. "Time, History, and the Social Sciences.” In The Varieties of History, From Voltaire to the Present, ed. Fritz Stern, 404-408. New York: Vintage Books, 1973.

Brigham Young University, Expected Learning Outcomes, http://www.byu.edu/webapp/home/index.jsp, found on March 20, 2008. as found on

Brigham Young University Hawaii, College of Arts and Sciences, Department of History, https://apps.byuh.edu/apps/pirat/Assessment/Academic_Programs/Outcomes.php?deptid=9, March 24, 2008.

Brigham Young University Idaho, Department of History, Program outcomes, http://www.byuh.edu/, found on March 20, 2008.

California State University, Fullerton, College of Humanities and Social Sciences, Department of History, as found on http://guides.library.fullerton.edu/infocomp/History/CSUF\%20History\%20Department\%20Stude nt\%20Learning\%20Outcomes.doc, March 20, 2008.

Carr, Edward H. What is history? The George Macaullay Trevelyan lectures delivered in the University of Cambridge January-March 1961. Hampshire: Macmillan, 1986.

Central Oregon Community College, Department of History, as found on http://socialscience.cocc.edu/Programs_Classes/History/History+Outcomes/default.aspx, March 24, 2008.

City College of New York, Department of History Learning Outcomes, http://extranet.adm.ccny.cuny.edu/middlestates/upload/History_MA_goalsgrid-2.pdf, found on March 20, 2008.

Champion, Timothy. "Beyond Egyptology: Egypt in the $19^{\text {th }}$ and $20^{\text {th }}$ Century Archaeology and Anthropology." In The Wisdom of Egypt: changing visions through the ages, ed. Peter Ucko and Timothy Champion, 161-185. London: University College London Press, 2003. 1994.

Cohen, David William. The Combing of History. Chicago: University of Chicago Press,

Columbia University, Department of History, as found on http://www.columbia.edu/cu/history/ugrad/main/handbook/major.html, March 1, 2008.

DePaul University, History Department, as found on http://condor.depaul.edu/ tla/html/DePaul\%20Learning\%20Outcomes/LA\&S/HIS\%20UG\%20L earn\%20Outcomes.doc, March 20, 2008. (page 230) 
Entwistle, Noel. "Promoting Deep Learning Through Teaching and Assessment." In Assessment to Promote Deep Learning, ed. Linda Suskie, 12-16. Washington DC: American Association for Higher Education, 2001.

Finley, M.I. Ancient History. Evidence and Models. London: Chatto \& Windus, 1985.

Graff, Gerald. Clueless in Academe: how schooling obscures the life of the mind. New Haven: Yale University Press, 2003.

Hatch, Gary. "The Volleyball Effect." In Writing Matters, BYU University Writing Newsletter 9/1 (2007): 1.

Hoffman, Micheal. Egypt Before the Pharaohs: the prehistoric foundations of Egyptian civilization. New York: Knopf, 1979.

Iowa State University, Department of History, as found on http://www.history.iastate.edu/assessment.pdf, March 20, 2008.

Jeffreys, David. ed, Views of Ancient Egypt since Napoleon Bonaparte: imperialism, colonialsm and modern appropriations. London: University College London Press, 2003. 2003.

Kitchen, Kenneth. On the Reliability of the Old Testament. Michigan: W. B. Eerdmans,

Mommsen, Theodor. "History and Literature." In The Varieties of History: Voltaire to the Present, ed. Fritz Stern, 192. New York: Vintage Books, 1973.

Morschauser, Scott. Threat-Formulae in Ancient Egypt. Baltimore: Halgo Inc., 1991.

Muhlestein, Kerry. "Empty Threats? How Egyptians' Self-Ontology Should Affect the Way We Read Many Texts." In The Journal of the Society for the Study of Egyptian Antiquities 34 (2007): 115-130.

Na'aman, Nadav. Ancient Israel's History and Historiography, The First Temple Period. Winona Lake, Indiana: Eisenbrains, 2006.

Norfolk State University, Department of History, as found on http://sola.nsu.edu/history/programoutcomes.doc, found on March 20, 2008.

North Carolina State University, Department of History, as found on http://www2.chass.ncsu.edu/cwsp/docs/hist_outcomes.pdf, March 20, 2008.

Oklahoma State University, Department of History, as found on http://uat.okstate.edu/assessment/assessment_at_osu/outcomes/CAS/CAS_OA2006/HistoryGrad-Assessment\%20Report\%202005-06.pdf, March 20, 2008. 
Oregon Community College,

http://socialscience.cocc.edu/Programs_Classes/History/History+Outcomes/default.aspx, found on March 20, 2008;

Pascarella, Ernest T. and Patrick T. Terenzini, How College Affects Students. Findings and Insights from Twenty Years of Research. Oxford: Jossey-Bass Publishers, 1991.

Redford, Donald. "History and Egyptology." In Egyptology Today, ed. Richard Wilkinson, 23-35. New York: Cambridge University Press, 2008.

Seton Hall University, http://academic.shu.edu/outcomes/Narratives/U_histories.htm, found on March 20, 2008.

St. Mary's University of Minnesota, Department of History, as found on http://www.smumn.edu/OCA/Departments/History/Maps/history_goals_outcomes.pdf, March $20,2008$.

Schorske, Carl E. Thinking with History. Explorations in the Passage to Modernism. Princeton: Princeton University Press, 1998.

Stern, Fritz. The Varieties of History. New York: Vintage Books, 1973.

Student Learning Assessment, Middle States Commission on Higher Education. Philadelphia: 2003.

Tate, Williamed. ed., "Never Had the Like Occurred,” Egypt's View of its Past, London: University College London Press, 2003. (page 231).

University of Anchorage Alaska www.uaa.alaska,edu/assessment/upload/HistoryAnalysisofResults6-15-06-.2.doc, found on March 20, 2008.

University of Arizona, General Outcomes, http//outcomes.web.arizona.edu/data.php?uid=474\&d=e\&exid=474, found on March 20, 2008.

University of California Merced, http://ssha.ucmerced.edu/, found on March 20, 2008.

University of Colorado at Boulder, Department of History, as found on http://www.colorado.edu/catalog/catalog07-08/index.html?s=2-37, March 24, 2008.

University of Nevada, Department of History Assessment Plan, http://online.unr.edu/apps/assess/subplan/History_Bach.pdf, found on March 20, 2008.

University of Texas El Paso, History Department Visson and Misson Statements, 
http://academics.utep.edu/Default.aspx?tabid=25524, found on March 20, 2008;

University of Washington, www.washington.edu/student/gencat/academic/history.html, found on March 20, 2008.

University of Utah, http://www.utah.edu/portal/site/uuhome/, found on March 20, 2008.

Van Seters, John. Prologue to History. Louisville, KY: Westminster/John Knox Press, 1992.

Willems, Harco. "Crime, Cult and Capital Punishment (Mo'alla Inscription 8)," JEA 76 (1990): 27-54.

Wright, Barbara. “Accreditation - Where Credit Is Due.” In Assessment to Promote Deep Learning, ed. Linda Suskie (Washington DC: American Association for Higher Education, 2001), 49, 54-58. 